\title{
A STUDY OF THE FACTORS AFFECTING COPPER CEMENTATION OF GOLD FROM AMMONIACAL THIOSULPHATE SOLUTION \\ by \\ EDUARD GUERRA
}

B.Sc., Laurentian University of Sudbury, 1993

B.Eng., Laurentian University of Sudbury, 1993

\section{A THESIS SUBMITTED IN PARTIAL FULFILLMENT OF THE REQUIREMENTS FOR THE DEGREE OF MASTER OF APPLIED SCIENCE in \\ THE FACULTY OF GRADUATE STUDIES}

Department of Metals and Materials Engineering

We accept this thesis as conforming to the required standard

THE UNIVERSITY OF BRITISH COLUMBIA

November 1997

(c) Eduard Guerra, 1997 
In presenting this thesis in partial fulfilment of the requirements for an advanced degree at the University of British Columbia, I agree that the Library shall make it freely available for reference and study. 1 further agree that permission for extensive copying of this thesis for scholarly purposes may be granted by the head of my department or by his or her representatives. It is understood that copying or publication of this thesis for financial gain shall not be allowed without my written permission.

Department of Metalsand Materials Engineering

The University of British Columbia

Vancouver, Canada

Date No0.26, 1997 


\begin{abstract}
Thiosulphate leaching of gold is a proposed alternative to cyanide leaching for certain types of refractory gold ores. The most promising method for recovering gold from thiosulphate leach solutions is by copper cementation. This study focused on determining how the factors of $\mathrm{pH} / \mathrm{ammonia}$ concentration, copper concentration, thiosulphate concentration, sulphite concentration, and temperature, commonly manipulated in thiosulphate leaching studies, affect gold cementation performance using copper. These factors were varied in artificial leach solutions according to the ranges typically found in literature. Both powder cementation and rotating disk electrode cementation were used to study the kinetics of gold cementation. Overall, the cementation of gold by copper from ammoniacal thiosulphate solution was concluded to be under mass transfer control. Higher temperatures and $\mathrm{pH} / \mathrm{ammonia}$ concentration were determined to positively affect the rate of gold cementation. Conversely, sulphite and copper in solution were established to negatively affect cementation performance.
\end{abstract}




\section{Table of Contents}

Abstract $\quad$ ii

List of Tables $\quad \mathrm{v}$

List of Figures vi vii

List of Symbols $\quad$ viii

Acknowledgements $\quad x$

1 Introduction 1

2 Literature Review 3

2.1 Thiosulphate Leaching of Gold 3

2.1.1 Stabilisation of Thiosulphate 3

2.1.2 Acceleration of Leaching 6

2.2 Recovery of Gold from Thiosulphate Solution $\quad 8$

2.2.1 Reduction-Precipitation of Gold by Reaction with 8 Borohydride

2.2.2 Substitution of Thiosulphate with Cyanide 9

2.2.3 Cementation of Gold from Thiosulphate Solution 9

$\begin{array}{lll}\text { 2.2.3.1 Iron Cementation of Gold } & 10\end{array}$

2.2.3.2 Zinc Cementation of Gold 11

2.2.3.3 Copper Cementation of Gold 12

2.3 Theoretical Fundamentals of Cementation 13

$\begin{array}{ll}2.3 .1 \text { Kinetics of Cementation Reactions } & 13\end{array}$

2.3.1.1 Chemical Rate Control in Cementation $\quad 15$

2.3.1.2 Mass Transfer Control in Cementation 16

2.4 Experimental Methods in Kinetic Studies of Cementation Systems 18

2.4.1 Solution Analysis 18

2.4.2 Powder Cementation 19

2.4.3 Rotating Disk Electrode Cementation $\quad 19$

2.4.4 Analysis of Reductant Substrate $\quad 20$

2.4.5 Determination of Activation Energy 20

2.5 Factorial Design 20

$\begin{array}{lll}2.6 & \text { Summary } & 23\end{array}$

3 Experimental Approach $\quad 25$

3.1 Powder Cementation $\quad 25$

3.1.1 Experiments to Establish Reproducibility and Rate Control Regime 27

$\begin{array}{ll}\text { 3.1.2 Fractional Factorial Design Experiment } & 28\end{array}$

$\begin{array}{ll}3.2 \text { Rotating Disk Electrode Experiments } & 30\end{array}$

4 Results and Discussion $\quad 33$

4.1 Results of the Powder Cementation Experiments Testing Reproducibility 33

4.1.1 X-ray Diffraction Evidence of Formation of a Copper-Containing 36 Deposit 
4.1.2 Modelled Results

4.2 Results of the Powder Cementation Experiments to Determine the Rate 39 Control Regime

4.3 Results of the Fractional Factorial Design Experiment

4.3.1 Effect of Sulphite Concentration

4.3.2 Effect of $\mathrm{pH} / \mathrm{ammonia}$ Concentration

4.3.3 Effect of Temperature 48

4.3.4 Effect of Copper Concentration 48

4.4 Results of the Rotating Disk Electrode Experiments $\quad 50$

4.5 Summary 51

5 Conclusions $\quad 53$

6 References $\quad 54$

Appendix A: Procedure for Preparation of Standard Solutions Used for Atomic 57 Absorption Spectroscopy Analysis

Appendix B: Procedure for Analysis of Thiosulphate in the Presence of Sulphite, Sulphate, Copper(II) and Ammonia-Ammonium Buffer

Appendix C: Procedure for Determination of Ammonia in Solution 60

Appendix D: Derivation of the 'Passivation' Model 61

Appendix E: Analysis of Variance of $\mathrm{k}_{1}{ }^{\prime} \quad 62$

Appendix F: Calculation of Free Energy Change for Reduction of Sulphite and 64 Thiosulphate to Chalcocite and Cuprite by Metallic Copper

Appendix G: Calculation of Theoretical Change in Sulphite Concentration Caused 66 by Reduction of Sulphite on Metallic Copper to Cuprite and Chalcocite

$\begin{array}{ll}\text { Appendix H: } & \text { Results of Thiosulphate Analyses }\end{array}$

Appendix I: Data from Powder Cementation Experiments Testing Reproducibility 68

Appendix J: Data from Powder Cementation Experiments to Determine the Rate 69 Control Regime

$\begin{array}{ll}\text { Appendix K: Data from Factorial Experiment } & 70\end{array}$

Appendix L: Data from RDE Experiments $\quad 72$

Appendix M: Thermodynamic Data $\quad 73$ 


\section{List of Tables}

Table 3.1: $\quad$ Solution Conditions for Reproducibility Experiments 27

Table 3.2: $\quad$ Experimental Design Layout for the Factorial Design Experiment 29

Table 3.3: Experimental Conditions of RDE Experiments. Initial Conditions: 12.532 ppm Au, $0.32 \mathrm{~mol} / / \mathrm{NH}_{3}(\mathrm{pH} 10.1), 0.2 \mathrm{~mol} / \mathrm{l} \mathrm{S}_{2} \mathrm{O}_{3}{ }^{2-}, \mathrm{V}_{\text {avg }} 985 \mathrm{ml}$

Table 4.1: $\quad$ Modelled Results of Experiments Testing Reproducibility. Initial

Conditions: $13.33 \mathrm{ppm} \mathrm{Au}, 0.73 \mathrm{~mol} / 1 \mathrm{NH}_{3}, 0.1 \mathrm{~mol} / 1 \mathrm{~S} \mathrm{~S}_{2} \mathrm{O}_{3}{ }^{2-}, 0.1 \mathrm{~mol} / 1$ $\mathrm{SO}_{3}^{2-}, 1.0 \mathrm{~g} / \mathrm{C} \mathrm{Cu}^{2+}, 50^{\circ} \mathrm{C}, 3.75$ litre solution, $5.00 \mathrm{~g} \mathrm{Cu}$ powder

Table 4.2: $\quad$ Modelled Results of Experiments to Determine the Rate Control

Regime. Initial Conditions: $13.33 \mathrm{ppm} \mathrm{Au}, 0.73 \mathrm{~mol} / / \mathrm{NH}_{3}, 0.1 \mathrm{~mol} / \mathrm{l}$ $\mathrm{S}_{2} \mathrm{O}_{3}^{2-}, 0.1 \mathrm{~mol} / 1 \mathrm{SO}_{3}^{2-}, 1.0 \mathrm{~g} / \mathrm{C} \mathrm{Cu}^{2+}, 3.75$ litre solution, $5.00 \mathrm{~g} \mathrm{Cu}$ powder

Table 4.3: $\quad$ Modelled Results of Factorial Design Experiment

Table 4.4: Equilibrium Gold Speciation . $\quad 48$

Table 4.5: Equilibrium Ratio of Cupric Tetrammine to Cuprous-Thiosulphate 49 Complex Under Standard Solution Conditions

Table 4.6: Modelled Results of RDE Experiments. Initial Conditions: $12.5 \mathrm{ppm}$ $\mathrm{Au}, 0.32 \mathrm{~mol} / \mathrm{l} \mathrm{NH}_{3}(\mathrm{pH} 10.1), 0.2 \mathrm{~mol} / \mathrm{l} \mathrm{S}_{2} \mathrm{O}_{3}{ }^{2-}, \mathrm{V}_{\text {avg }} 985 \mathrm{ml}$ 


\section{List of Figures}

Figure 2.1: Gold-Ammonia-Thiosulphate-Water $\mathrm{E}_{\mathrm{h}} \mathrm{pH}$ Diagram at $25^{\circ} \mathrm{C} .10 \mathrm{ppm} \quad 4$ $\mathrm{Au}, 1.0 \mathrm{~mol} / 1 \mathrm{NH}_{3}, 0.1 \mathrm{~mol} / \mathrm{l} \mathrm{S}_{2} \mathrm{O}_{3}{ }^{2-}$

Figure 2.2: $\quad$ Sulphur-Water $\mathrm{E}_{\mathrm{h}}-\mathrm{pH}$ Diagram at $25^{\circ} \mathrm{C} .1 .0 \mathrm{~mol} / \mathrm{l} \mathrm{S}$

Figure 2.3: $\quad$ Metastable Sulphur-Water $\mathrm{E}_{\mathrm{h}}-\mathrm{pH}$ Diagram at $25^{\circ} \mathrm{C} .1 .0 \mathrm{~mol} / \mathrm{l} \mathrm{S}$

Figure 2.4: Copper-Ammonia-Thiosulphate-Sulphite-Water $\mathrm{E}_{\mathrm{h}}-\mathrm{pH}$ Diagram at 7 $25^{\circ} \mathrm{C} .0 .1 \mathrm{~g} / \mathrm{l} \mathrm{Cu}, 1.0 \mathrm{~mol} / 1 \mathrm{NH}_{3}, 0.1 \mathrm{~mol} / 1 \mathrm{~S}_{2} \mathrm{O}_{3}{ }^{2-}, 0.1 \mathrm{~mol} / 1 \mathrm{SO}_{3}{ }^{2-}$

Figure 2.5: $\quad$ Mechanism of Copper Catalysed Ammoniacal Thiosulphate Leaching $\quad 7$ of Gold

Figure 2.6: Iron-Ammonia-Thiosulphate-Water $\mathrm{E}_{\mathrm{h}}$ - $\mathrm{pH}$ diagram at $25^{\circ} \mathrm{C} .0 .1 \mathrm{~g} / \mathrm{Fe}, \quad 10$ $1.0 \mathrm{~mol} / 1 \mathrm{NH}_{3}, 0.1 \mathrm{~mol} / 1 \mathrm{~S}_{2} \mathrm{O}_{3}{ }^{2-}$

Figure 2.7: Zinc-Ammonia-Thiosulphate-Water $\mathrm{E}_{\mathrm{h}}$-pH Diagram at $25^{\circ} \mathrm{C} .0 .1 \mathrm{~g} / \mathrm{Zn}, \quad 11$ $1.0 \mathrm{~mol} / 1 \mathrm{NH}_{3}, 0.1 \mathrm{~mol} / 1 \mathrm{~S}_{2} \mathrm{O}_{3}{ }^{2-}$

$\begin{array}{lll}\text { Figure 2.8: } & \text { Physical Steps of a Simple Cementation Reaction } & 14\end{array}$

Figure 2.9: Reaction Co-ordinate Diagram of an Anodic Dissolution Reaction 16

Figure 2.10: Matrix Form of a Three Factor, High-Low, Factorial Design 21

Figure 2.11: $\quad$ Matrix Form of a Five Factor, High-Low, Fractional Factorial Design 22

Figure 3.1: $\quad$ Powder Cementation Reactor $\quad 26$

Figure 3.2: $\quad$ RDE Cementation Set-up 30

Figure 3.3: $\quad$ Shaft and Rotating Disk Electrode Assembly 31

Figure 4.1: Behaviour of $\mathrm{pH}$. Initial Conditions: $13.33 \mathrm{ppm} \mathrm{Au}, 0.73 \mathrm{~mol} / \mathrm{l} \mathrm{NH}, \quad 33$ $0.1 \mathrm{~mol} / 1 \mathrm{~S}_{2} \mathrm{O}_{3}{ }^{2-}, 0.1 \mathrm{~mol} / 1 \mathrm{SO}_{3}{ }^{2-}, 1.0 \mathrm{~g} / 1 \mathrm{Cu}^{2+}, 50^{\circ} \mathrm{C}, 3.75$ liltre solution, $5.00 \mathrm{~g} \mathrm{Cu}$ powder

Figure 4.2: Behaviour of Solution Potential. Initial Conditions: $13.33 \mathrm{ppm} \mathrm{Au}$, $0.73 \mathrm{~mol} / 1 \mathrm{NH}_{3}, 0.1 \mathrm{~mol} / 1 \mathrm{~S} \mathrm{~S}_{2} \mathrm{O}_{3}{ }^{2-}, 0.1 \mathrm{~mol} / 1 \mathrm{SO}_{3}{ }^{2-}, 1.0 \mathrm{~g} / \mathrm{Cu}^{2+}, 50^{\circ} \mathrm{C}$, 3.75 litre solution, $5.00 \mathrm{~g} \mathrm{Cu}$ powder 
Figure 4.3: Gold Removal. Initial Conditions: $13.33 \mathrm{ppm} \mathrm{Au}, 0.73 \mathrm{~mol} / \mathrm{l} \mathrm{NH}_{3}, 0.1$

$\mathrm{mol} / 1 \mathrm{~S}_{2} \mathrm{O}_{3}{ }^{2-}, 0.1 \mathrm{~mol} / \mathrm{l} \mathrm{SO}_{3}{ }^{2-}, 1.0 \mathrm{~g} / \mathrm{l} \mathrm{Cu}^{2+}, 50^{\circ} \mathrm{C}, 3.75$ litre solution, $5.00 \mathrm{~g} \mathrm{Cu}$ powder

Figure 4.4: Comparison of Fit Between 'Passivation' Model and 'Linear' Model 36 to Averaged Data. Initial Conditions: $13.33 \mathrm{ppm} \mathrm{Au,} 0.73 \mathrm{~mol} / 1 \mathrm{NH}_{3}$, $\mathrm{mol} / 1 \mathrm{~S}_{2} \mathrm{O}_{3}{ }^{2-}, 0.1 \mathrm{~mol} / \mathrm{l} \mathrm{SO}_{3}{ }^{2-}, 1.0 \mathrm{~g} / \mathrm{l} \mathrm{Cu}^{2+}, 50^{\circ} \mathrm{C}, 3.75$ litre solution, $5.00 \mathrm{~g} \mathrm{Cu}$ powder

Figure 4.5: X-ray Diffraction Analysis of Copper Powder Residue of Reproducibility Experiment

Figure 4.6: X-ray Diffraction Analysis of Raw Copper Powder After Filtering and 37 Drying

Figure 4.7: Copper Powder Before Cementation. Magnification 200X

Figure 4.8: Morphology of Gold Deposits on Copper Powder Residue.

Magnification 3000X. Initial Conditions: $13.33 \mathrm{ppm} \mathrm{Au,} 0.73 \mathrm{~mol} / 1$ $\mathrm{NH}_{3}, 0.1 \mathrm{~mol} / \mathrm{l} \mathrm{S}_{2} \mathrm{O}_{3}{ }^{2-}, 0.1 \mathrm{~mol} / \mathrm{l} \mathrm{SO}_{3}{ }^{2-}, 1.0 \mathrm{~g} / 1 \mathrm{Cu}^{2+}, 3.75$ litre solution, $5.00 \mathrm{~g} \mathrm{Cu}$ powder

Figure 4.8: Arrhenius Plot for Gold Cementation. Initial Conditions: $13.33 \mathrm{ppm}$ $\mathrm{Au}, 0.73 \mathrm{~mol} / 1 \mathrm{NH}_{3}, 0.1 \mathrm{~mol} / \mathrm{l} \mathrm{S}_{2} \mathrm{O}_{3}{ }^{2-}, 0.1 \mathrm{~mol} / 1 \mathrm{SO}_{3}{ }^{2-}, 1.0 \mathrm{~g} / 1 \mathrm{Cu}^{2+}$, 3.75 litre solution, $5.00 \mathrm{~g} \mathrm{Cu}$ powder

Figure 4.10: Normal Probability Plot for $\mathrm{k}_{1}{ }^{\prime}$

Figure 4.11: Normal Distribution Plot for $\mathrm{k}_{2}{ }^{\prime}$

Figure 4.12: Normal Probability Plot for $\mathrm{k}_{2}{ }^{\prime} / \mathrm{k}_{1}{ }^{\prime}$

Figure 4.13: Morphology of Sulphur Deposits on Copper Powder Residue. Magnification 3000X

Figure 4.14: Arrhenius Plot Using Adjusted Rate Constant. Initial Conditions: 12.5 ppm Au, $0.32 \mathrm{~mol} / \mathrm{l} \mathrm{NH} 3\left(\mathrm{pH} \mathrm{10.1)}, 0.2 \mathrm{~mol} / \mathrm{l} \mathrm{S}_{2} \mathrm{O}_{3}{ }^{2-}, \mathrm{V}_{\text {avg }} 985 \mathrm{ml}\right.$ 


\section{List of Symbols}

$\alpha \quad$ proportion of overpotential accelerating a forward reaction

$\delta \quad$ boundary layer thickness

$\eta \quad$ overpotential

$v \quad$ viscosity

$\omega \quad$ angular velocity

$\sigma^{2} \quad$ variance

$\sigma \quad$ standard deviation

a activity

A reaction surface area

C concentration of reactant

$\mathrm{C}_{0} \quad$ concentration of reactant at time zero

$\mathrm{C}_{\mathrm{t}} \quad$ concentration of reactant at time $\mathrm{t}$

$\mathrm{CV}$ coefficient of variance

$D_{c}$ diffusion coefficient of $C$

E equilibrium or reversible reduction potential

$\mathrm{E}^{\circ} \quad$ standard reduction potential

$\mathrm{E}_{\mathrm{m}} \quad$ corrosion or mixed potential

F Faraday constant $(96485 \mathrm{C} / \mathrm{mol})$

$\Delta \mathrm{G}^{\circ} \quad$ standard change in free energy

$\Delta \mathrm{G}^{*} \quad$ activation energy

$\Delta G_{\mathrm{op}}$ associated change in free energy due to an overpotential

J molar flux 
$\mathrm{k} \quad$ reaction rate constant

$\mathrm{mV}$ millivolt

n number of electrons transferred in a reaction *

$\mathrm{n} \quad$ order of reaction *

n number of degrees of freedom *

$\mathrm{n}_{\mathrm{c}} \quad$ rate of mass transport of $\mathrm{C}$

$\mathrm{R}$ universal gas constant $(8.3144 \mathrm{~J} / \mathrm{mol} . \mathrm{K})$

$\mathrm{R}^{2} \quad$ correlation coefficient

$\mathrm{R}_{\mathrm{e}} \quad$ Reynolds number

t time

T absolute temperature

$\mathrm{V} \quad$ volume of solution

$\mathrm{x} \quad$ co-ordinate in space

* Correct use of symbol is implicit from context 


\section{Acknowledgements}

The completion of this study could not have possible without contributions from a great number of sources. Firstly, I would like to thank Dr. David Dreisinger, my thesis supervisor, for his patience and guidance. Thanks to Dr. Jinxing Ji for helping with the design of my reactors and for translating some Chinese papers. I would also like to thank Dr. Berend Wassink for helping to develop my analytical procedures. I am also grateful to Victoire van der Pas for helping me with the SEM and Anita Lam for helping me with my AAS protocols and teaching me how to use the $\mathrm{X}$-ray diffraction analyser. Thank you to all of my fellow graduate students, Ben Saito and Nathan Swami in particular, for assisting in various things and keeping me entertained over the years. I would also like to my dear friend Carlos Pinheiro and his wife Rose for taking me into their home in Vancouver while I finished my thesis. A special thank you goes to my family for their support, both financial and emotional, of my decision to return to school in order to complete my degree. Lastly, I would like to thank Jesus Christ, my Lord and Saviour, for His spiritual strength and guidance. 


\section{Introduction}

Thiosulphate leaching, or more precisely, copper catalysed ammoniacal thiosulphate leaching, is an alternative to cyanide leaching for certain gold ores to which cyanide is not readily applicable. These gold ores are termed 'refractory' since they contain certain characteristic components which will either cause excessive reagent consumption or unacceptable losses of gold to tailings. In particular, ores containing significant amounts of copper minerals and/or preg robbing carbonaceous material are candidates for the application of thiosulphate leaching. Also of note is the fact that thiosulphate is relatively innocuous in contrast to the highly toxic nature of cyanide.

Thiosulphate leaching is carried out at an alkaline $\mathrm{pH}$ in the range of, typically, 9.0 to 10.5 and a temperature between $20^{\circ} \mathrm{C}$ and $60^{\circ} \mathrm{C}$. Though oxygen is the principal electron acceptor in leaching, the cuprous/cupric couple is used to catalyse oxidation. Ammonia is added in order to maintain the solubility of cupric ions as cupric tetrammine, $\mathrm{Cu}\left(\mathrm{NH}_{3}\right)_{4}{ }^{2+}$, and to catalyse the anodic dissolution of gold. Gold is ultimately complexed by thiosulphate as bis(thiosulphato)aurate( $(\mathrm{I}), \mathrm{Au}\left(\mathrm{S}_{2} \mathrm{O}_{3}\right)_{2}{ }^{3-}$. Thiosulphate is a metastable sulphur species and will eventually decompose in aqueous solutions. Its stability, however, may be enhanced by the presence of sulphite ions.

Since thiosulphate leaching of gold is, as yet, commercially undeveloped, there is no accepted method for recovery of gold from thiosulphate leach solutions. Though there have been several proposed methods for recovering gold, cementation using copper was selected as most worthy of examination since it is the most amenable for use with a leach solution which is recirculated ${ }^{[1,2]}$. Research, thus far, has paid very little attention to recovery of gold from thiosulphate leach solutions and, as a result, virtually nothing is known about how solution characteristics affect cementation performance. An industrial operation that recycles leach solution would require this type of information in order to optimise their gold recovery stage. The objective of this work was to examine how the aforementioned parameters of $\mathrm{pH} / \mathrm{ammonia}$ concentration, copper concentration, thiosulphate concentration, sulphite concentration, and temperature, commonly 
manipulated in thiosulphate leaching studies, affect gold cementation performance using copper. In doing so, the regime of rate control will also be determined, i.e. whether the system is under mass transfer control or chemical reaction control will be established.

The results of this study are presented in four parts. The literature review examines thiosulphate leaching of gold including some proposed methods for recovery of gold as well as some general theory of cementation. In addition, since factorial design was used in the experimental design, a brief introduction to factorial design is submitted. The section covering the experimental approach is divided into two parts, powder cementation and rotating disk electrode (RDE) cementation. A review and summary of the experimental results follows. Lastly, the conclusions of the research are presented. 


\section{Literature Review}

\subsection{Thiosulphate Leaching of Gold}

The use of thiosulphate as a lixiviant for gold was first documented in the early twentieth century in what was known as von Patera's process, in which gold and silver were leached after being subjected to a chloridising roast. The dissolution of gold utilises oxygen as the ultimate electron accepting species.

$\mathrm{Au}+\mathrm{S}_{2} \mathrm{O}_{3}{ }^{2-}+\mathrm{O}_{2}+2 \mathrm{H}_{2} \mathrm{O} \rightarrow 4 \mathrm{Au}\left(\mathrm{S}_{2} \mathrm{O}_{3}\right)_{2}{ }^{3-}+4 \mathrm{OH}^{-}$

The resulting gold-thiosulphate complex, bis(thiosulphato)aurate(I), does not effectively adsorb onto activated carbon ${ }^{[3,4]}$. This characteristic allows thiosulphate leaching to be applied to gold ores that contain active, preg robbing, carbonaceous material. Gold ores with significant levels of copper minerals are also candidates for thiosulphate leaching. Although, similar to cyanide, thiosulphate will dissolve copper minerals, this is of less concern since, as will be explained, the presence of copper in solution is beneficial for gold dissolution.

Modifications have recently been made to the leaching process so that it now has the potential of being applied directly to refractory gold ores. The suggested $\mathrm{pH}$ range for leaching is between 9.5 and 10.5 while the solution $E_{h}$ should range between 0.1 and 0.2 $\mathrm{mV}^{[5]}$. The aforementioned ranges of $\mathrm{E}_{\mathrm{h}}$ and $\mathrm{pH}$, as well as the modifications alluded to, assist in either stabilisation of thiosulphate or acceleration of leaching kinetics and will be discussed in the following sections.

\subsubsection{Stabilisation of Thiosulphate}

Inspection of the gold-ammonia-thiosulphate-water $\mathrm{E}_{\mathrm{h}}$-pH diagram, Figure 2.1, indicates that dissolution of gold can take place at relatively low potentials and over a wide $\mathrm{pH}$ range. However, this is misleading since, in the construction of the diagram, the 
decomposition of thiosulphate must be ignored. In fact, as demonstrated in the sulphurwater $\mathrm{E}_{\mathrm{h}}$ - $\mathrm{pH}$ diagram, Figure 2.2, thiosulphate has no dominant region in aqueous solution. It is only when sulphate formation is omitted in the construction of a metastable sulphur-water $\mathrm{E}_{\mathrm{h}} \mathrm{pH}$ diagram, Figure 2.3, that allows for evaluation of the $\mathrm{E}_{\mathrm{h}}$ and $\mathrm{pH}$ conditions which enhance thiosulphate stability, e.g. mildly oxidising or reducing $E_{h}$ and alkaline $\mathrm{pH}$.

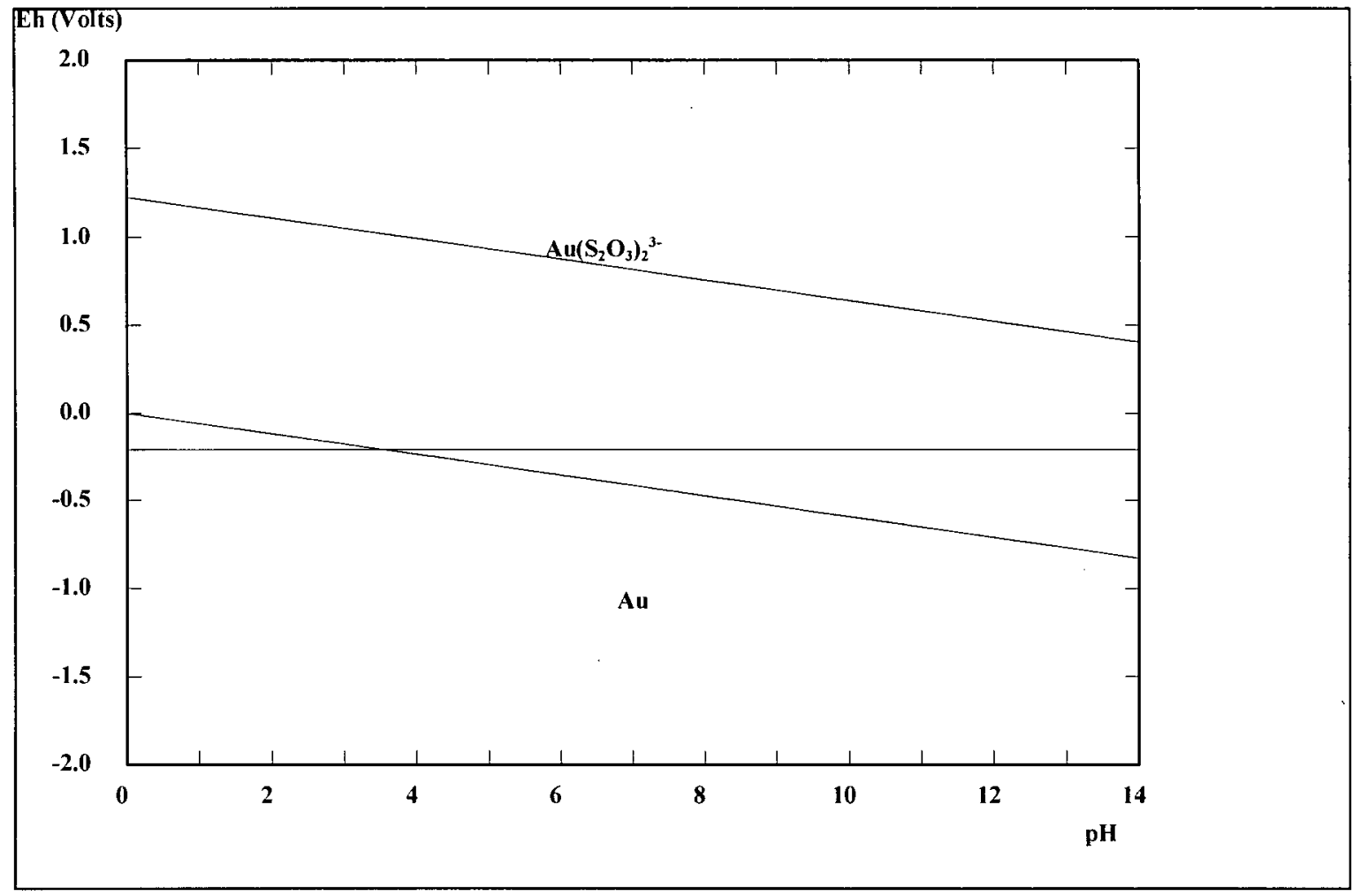

Figure 2.1: Gold-Ammonia-Thiosulphate-Water $\mathrm{E}_{\mathrm{h}}$-pH Diagram at $25^{\circ} \mathrm{C} .10 \mathrm{ppm} \mathrm{Au}$, $1.0 \mathrm{~mol} / 1 \mathrm{NH}_{3}, 0.1 \mathrm{~mol} / 1 \mathrm{~S}_{2} \mathrm{O}_{3}{ }^{2-}$ 


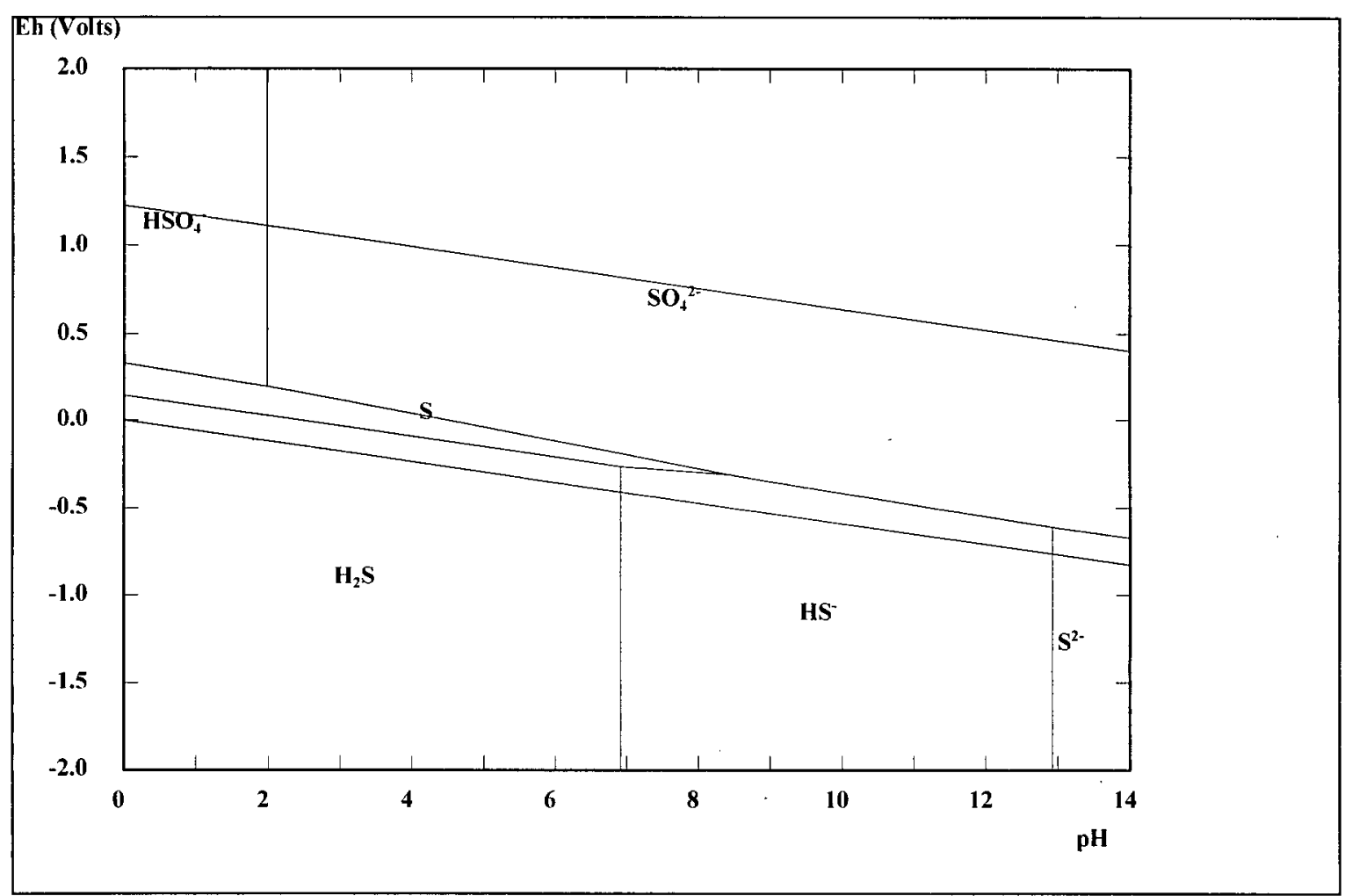

Figure 2.2: Sulphur-Water $\mathrm{E}_{\mathrm{h}}$-pH Diagram at $25^{\circ} \mathrm{C} .1 .0 \mathrm{~mol} / \mathrm{l} \mathrm{S}$

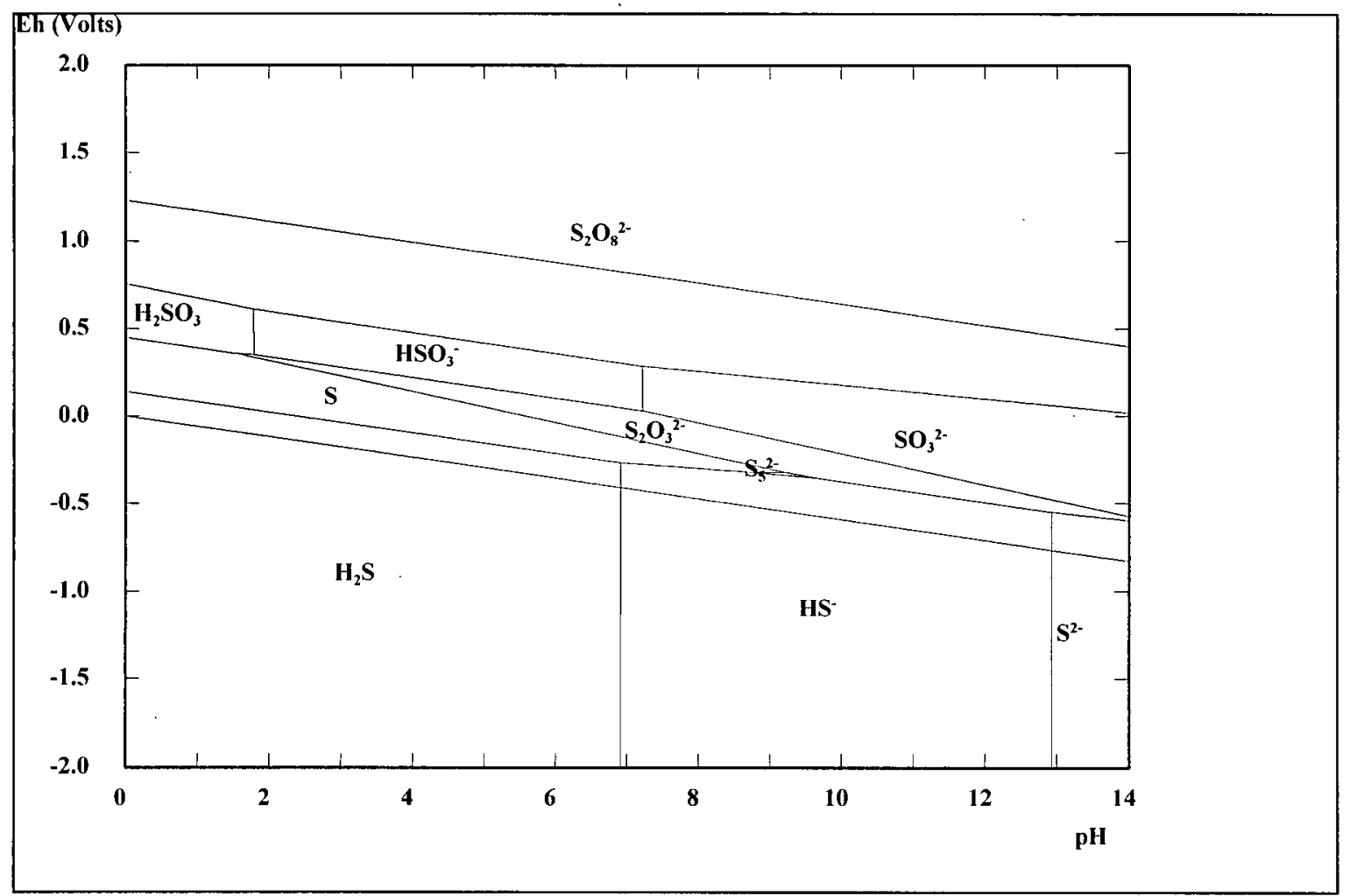

Figure 2.3: Metastable Sulphur-Water $\mathrm{E}_{\mathrm{h}}-\mathrm{pH}$ Diagram at $25^{\circ} \mathrm{C} .1 .0 \mathrm{~mol} / \mathrm{l} \mathrm{S}$ 
The first stage in thiosulphate decomposition is oxidation of thiosulphate to tetrathionate by reaction with dissolved oxygen or a metal ion in solution.

$$
\begin{aligned}
& 4 \mathrm{~S}_{2} \mathrm{O}_{3}{ }^{2-}+\mathrm{O}_{2}+2 \mathrm{H}_{2} \mathrm{O} \rightarrow 2 \mathrm{~S}_{4} \mathrm{O}_{6}{ }^{2-}+4 \mathrm{OH}^{-} \\
& 2 \mathrm{~S}_{2} \mathrm{O}_{3}{ }^{2-}+2 \mathrm{M}^{(\mathrm{n}+1)+} \rightarrow \mathrm{S}_{4} \mathrm{O}_{6}{ }^{2-}+2 \mathrm{M}^{\mathrm{n}+}
\end{aligned}
$$

Thiosulphate can be stabilised via the addition of a small amount of sulphite during leaching which reacts with tetrathionate and sulphide ions to reform thiosulphate ${ }^{[6,7,8]}$.

$\mathrm{S}_{4} \mathrm{O}_{6}{ }^{2-}+\mathrm{SO}_{3}{ }^{2-} \rightarrow \mathrm{S}_{3} \mathrm{O}_{6}{ }^{2-}+\mathrm{S}_{2} \mathrm{O}_{3}^{2-}$

$2 \mathrm{~S}^{2-}+4 \mathrm{SO}_{3}^{2-}+3 \mathrm{H}_{2} \mathrm{O} \rightarrow 3 \mathrm{~S}_{2} \mathrm{O}_{3}^{2-}+6 \mathrm{OH}^{-}$

By reacting with sulphide ions, sulphite prevents the precipitation of metal sulphides which can form a passivating layer on gold particles, thereby, blocking their dissolution ${ }^{[7]}$.

\subsubsection{Acceleration of Leaching}

Ammonia and copper play important roles in catalysing thiosulphate leaching of gold. As indicated by the copper-ammonia-thiosulphate-sulphite-water $\mathrm{E}_{\mathrm{h}} \mathrm{pH}$ diagram, Figure 2.4 , ammonia is able to solubilise cupric ions, as predominantly cupric tetrammine, $\mathrm{Cu}\left(\mathrm{NH}_{3}\right)_{4}{ }^{2+}$, in the $\mathrm{pH}$ and $\mathrm{E}_{\mathrm{h}}$ range of thiosulphate leaching. At cathodic sites on gold particles cupric tetrammine is reduced to cuprous diammine, $\mathrm{Cu}\left(\mathrm{NH}_{3}\right)_{2}{ }^{+}$, which subsequently reacts with dissolved oxygen to regenerate cupric tetrammine ${ }^{[9]}$. At anodic sites on the gold surface, ammonia complexes gold entering solution as diamminegold(I), $\mathrm{Au}\left(\mathrm{NH}_{3}\right)_{2}{ }^{+}$. Thiosulphate then substitutes ammonia to eventually form the goldthiosulphate complex ${ }^{[10]}$. The catalytic mechanism of thiosulphate leaching of gold is represented by Figure 2.5 . 


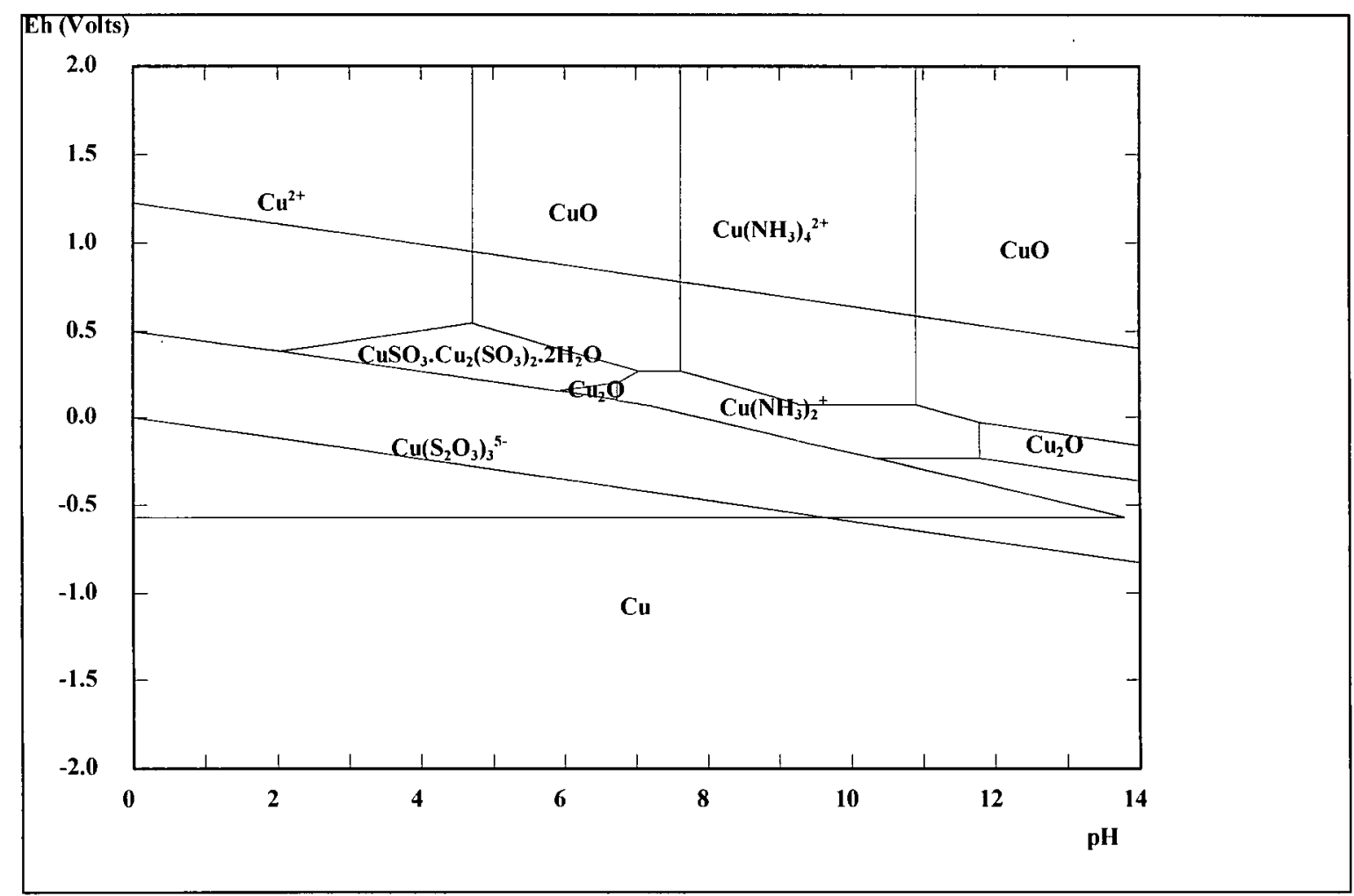

Figure 2.4: Copper-Ammonia-Thiosulphate-Sulphite-Water $\mathrm{E}_{\mathrm{h}}$-pH Diagram at $25^{\circ} \mathrm{C} .0 .1$ $\mathrm{g} / 1 \mathrm{Cu}, 1.0 \mathrm{~mol} / 1 \mathrm{NH}_{3}, 0.1 \mathrm{~mol} / 1 \mathrm{~S}_{2} \mathrm{O}_{3}{ }^{2-}, 0.1 \mathrm{~mol} / 1 \mathrm{SO}_{3}{ }^{2-}$

Anodic Area

Figure 2.5: Mechanism of Copper Catalysed Ammoniacal Thiosulphate Leaching of Gold $^{[10]}$ 
Though the gold-ammine complex, $\mathrm{Au}\left(\mathrm{NH}_{3}\right)_{2}{ }^{+}$, does not appear in the gold-thiosulphateammonia-water $\mathrm{E}_{\mathrm{h}} \mathrm{-pH}$ diagram, its presence in solution can be significant at low thiosulphate concentrations. Ammonia at high concentrations will form a precipitate, $\left(\mathrm{NH}_{4}\right)_{5} \mathrm{Cu}\left(\mathrm{S}_{2} \mathrm{O}_{3}\right)_{3}$, which can cover the surface of minerals, hindering gold dissolution ${ }^{[11]}$.

The 'optimal' temperature for leaching is subjective and is a function of a set of desired process characteristics, e.g. target levels of reagent consumption, recovery, and leaching time. Heap leach simulations, which were deemed promising, have been operated for two to three days near room temperature ${ }^{[12]}$. Leaching studies using stirred tank reactors, with leaching times in the order of minutes to a couple of hours, typically conclude an optimal temperature for leaching in the range of $35^{\circ} \mathrm{C}$ to $60^{\circ} \mathrm{C}$. Increasing temperature beyond $60^{\circ} \mathrm{C}$ begins to depress gold dissolution due to the formation of cupric sulphide on the surface of gold particles ${ }^{[7,9,13,14]}$. This has been indirectly attributed to the difficulty in retaining ammonia in solution at elevated temperature ${ }^{[6]}$.

$3 \mathrm{~S}_{2} \mathrm{O}_{3}{ }^{2-}+2 \mathrm{Cu}\left(\mathrm{NH}_{3}\right)_{4}{ }^{2+}+6 \mathrm{OH}^{-} \rightarrow 2 \mathrm{CuS} \downarrow+4 \mathrm{SO}_{3}{ }^{2-}+3 \mathrm{H}_{2} \mathrm{O}+8 \mathrm{NH}_{3} \uparrow$

\subsection{Recovery of Gold from Thiosulphate Solution}

Thiosulphate leaching of gold has yet to be successfully applied on a full commercial scale and hence, there is no accepted method for ultimate gold recovery. Reductionprecipitation of gold by reaction with borohydride, substitution of thiosulphate with cyanide (followed by a conventional gold cyanide adsorption circuit), and cementation are three proposed methods for gold recovery found in literature.

\subsubsection{Reduction-Precipitation of Gold by Reaction with Borohydride}

Gold can be quickly and selectively precipitated from thiosulphate solution by reaction with sodium borohydride at room temperature at a pH of between 5 to $7^{[15]}$.

$$
8 \mathrm{Au}\left(\mathrm{S}_{2} \mathrm{O}_{3}\right)_{2}{ }^{3-}+\mathrm{BH}_{4}{ }^{-}+10 \mathrm{OH}^{-} \rightarrow 8 \mathrm{Au}+\mathrm{BO}_{3}{ }^{3-}+7 \mathrm{H}_{2} \mathrm{O}+16 \mathrm{~S}_{2} \mathrm{O}_{3}{ }^{2-}
$$


Selectivity is achieved during $\mathrm{pH}$ adjustment by precipitating most impurities as oxides/hydroxides. Disadvantages of this process are the need for $\mathrm{pH}$ adjustment and the associated need for solution clarification and materials handling of the precipitates. In addition, it is not desirable to precipitate copper from a recycled solution since it is a necessary catalyst for leaching.

\subsubsection{Substitution of Thiosulphate with Cyanide}

Cyanide will readily substitute thiosulphate from bis(thiosulphato)aurate(I) to form dicyanoaurate(I).

$\mathrm{Au}\left(\mathrm{S}_{2} \mathrm{O}_{3}\right)_{2}{ }^{3-}+2 \mathrm{CN}^{-} \rightarrow \mathrm{Au}(\mathrm{CN})_{2}{ }^{-}+2 \mathrm{~S}_{2} \mathrm{O}_{3}{ }^{2-}$

It is claimed that the above reaction is so favoured to the right that only a stoichiometric amount of cyanide is necessary to convert all gold from the gold-thiosulphate state to the gold-cyanide complex ${ }^{[16]}$. Degradation of thiosulphate to thiocyanate does not occur significantly since the gold substitution reaction is much faster, leaving little free cyanide to react with excess thiosulphate.

$\mathrm{S}_{2} \mathrm{O}_{3}{ }^{2-}+\mathrm{CN}^{-} \rightarrow \mathrm{SCN}^{-}+\mathrm{SO}_{3}{ }^{2-}$

The resulting solution can be treated by any of the conventional gold recovery techniques applied after cyanide leaching, e.g. solvent extraction, ion exchange, or adsorption onto activated carbon.

\subsubsection{Cementation of Gold from Thiosulphate Solution}

Cementation is the electrochemical precipitation of one metal by using another metal as the reducing agent. Iron, zinc, and copper are elements that have been studied for use as cementing agents for gold from thiosulphate solution. 


\subsubsection{Iron Cementation of Gold}

Though iron has been suggested as a cementing agent for recovering gold, inspection of the iron-ammonia-thiosulphate-water $\mathrm{E}_{\mathrm{h}}-\mathrm{pH}$ diagram, Figure 2.6, reveals that there is no soluble form of iron which is dominant in the $\mathrm{E}_{\mathrm{h}}$ and $\mathrm{pH}$ range of thiosulphate leaching. It has been found that, prior to being added to solution, it is necessary to wash iron powder with dilute sulphuric acid to remove surface oxidation ${ }^{[3]}$. Some copper in solution is then cemented onto the freshly exposed metal surface prior to it being passivated by formation of an oxide/hydroxide layer. Most researchers have found that the cementation of copper onto iron is relatively rapid and under diffusion control leading to high surface area dendritic or botryoidal copper deposits ${ }^{[17,18]}$. Recovery of gold then proceeds via cementation onto the deposited copper. By increasing the quantity of iron added more copper is cemented from solution, thereby, increasing the amount of gold recovered over time ${ }^{[3]}$.

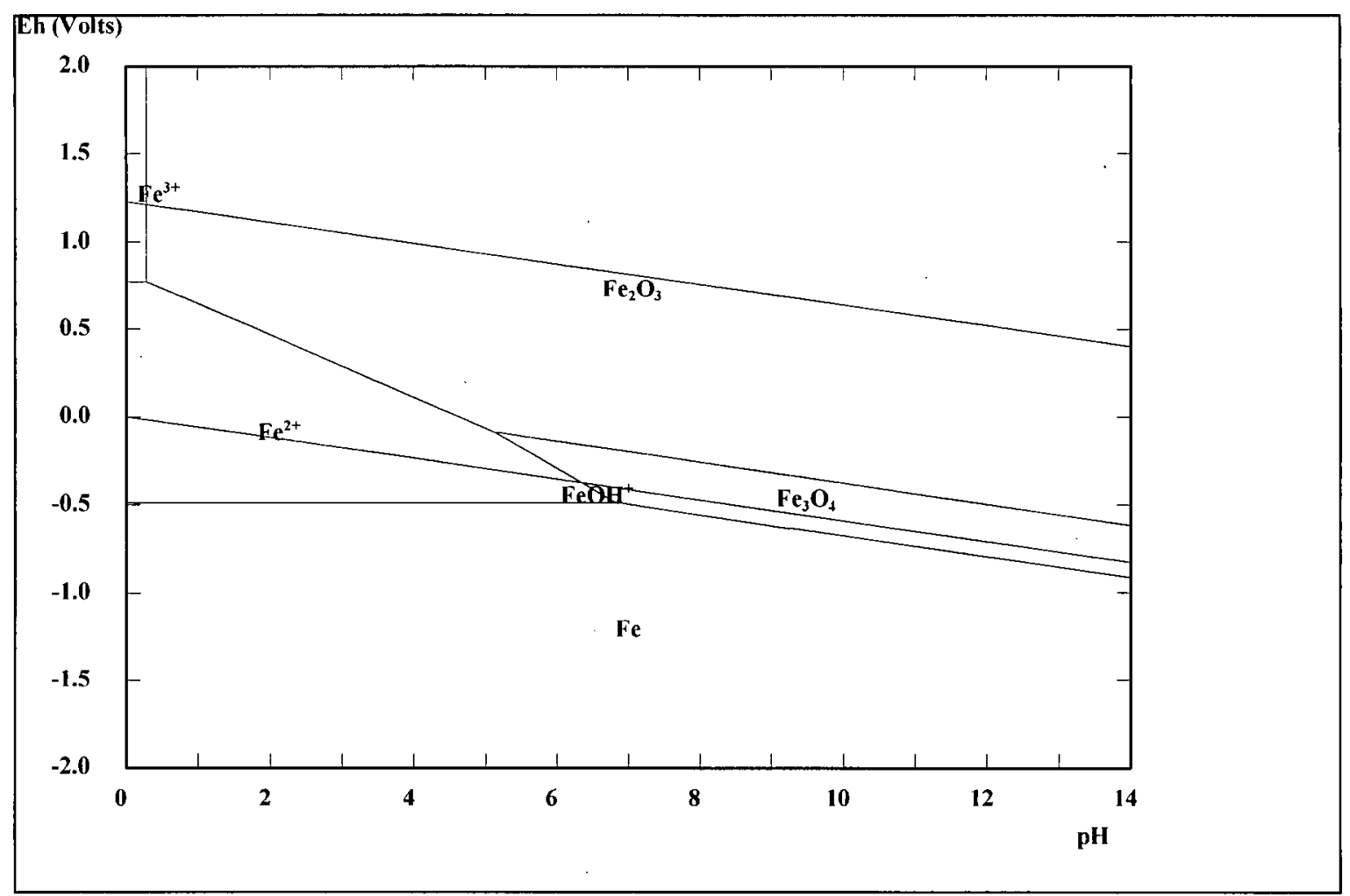

Figure 2.6: Iron-Ammonia-Thiosulphate-Water $\mathrm{E}_{\mathrm{h}} \mathrm{pH}$ diagram at $25^{\circ} \mathrm{C} .0 .1 \mathrm{~g} / \mathrm{Fe}, 1.0$ $\mathrm{mol} / 1 \mathrm{NH}_{3}, 0.1 \mathrm{~mol} / 1 \mathrm{~S} \mathrm{~S}_{2} \mathrm{O}_{3}{ }^{2-}$ 


\subsubsection{Zinc Cementation of Gold}

Zinc is a cementing agent historically used for recovering gold from cyanide leach solutions using the Merrill-Crowe process. Two possible paths by which gold may be recovered from alkaline cyanide solutions by reaction with zinc appear below:

$2 \mathrm{Au}(\mathrm{CN})_{2}{ }^{-}+\mathrm{Zn} \rightarrow 2 \mathrm{Au}+\mathrm{Zn}(\mathrm{CN})_{4}{ }^{2-}$

$2 \mathrm{Au}(\mathrm{CN})_{2}^{-}+\mathrm{Zn}+3 \mathrm{OH}^{-} \rightarrow 2 \mathrm{Au}+\mathrm{HZnO}_{2}^{-}+4 \mathrm{CN}^{-}+\mathrm{H}_{2} \mathrm{O}$

The rate of gold cementation follows first order kinetics and is controlled by mass transfer of $\mathrm{Au}(\mathrm{CN})_{2}{ }^{-[19]}$. Merrill first introduced the use of immensely high surface area zinc dust, as opposed to zinc shaving, to cement gold from solution in 1904. Later, Crowe improved the industrial process by deaerating the leach solution in a vacuum tower prior to addition of zinc. The removal of dissolved oxygen accelerated the rate of reduction of gold and decreased the consumption of zinc.

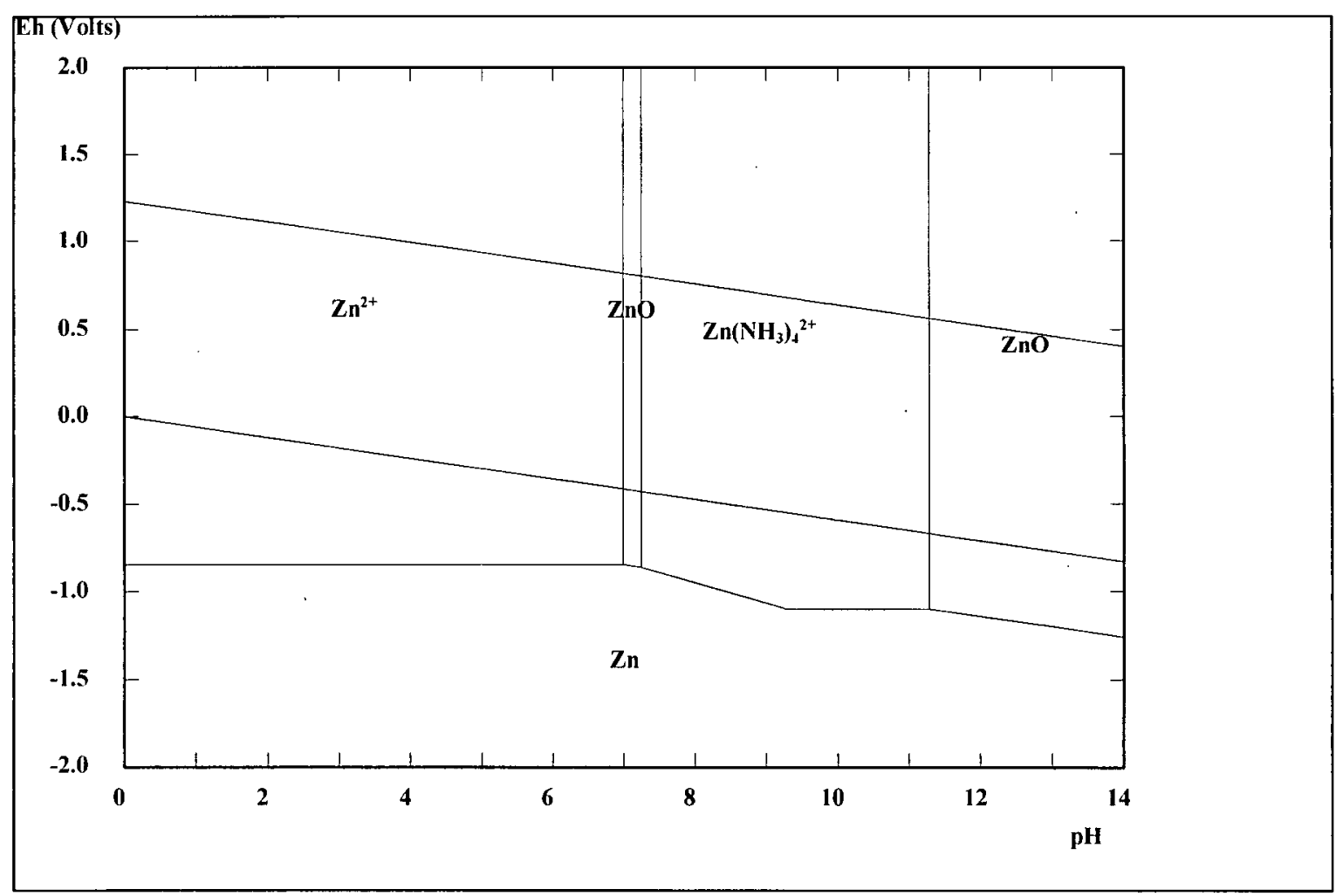

Figure 2.7: Zinc-Ammonia-Thiosulphate-Water $\mathrm{E}_{\mathrm{h}}$-pH Diagram at $25^{\circ} \mathrm{C} .0 .1 \mathrm{~g} / \mathrm{Zn}, 1.0$ $\mathrm{mol} / 1 \mathrm{NH}_{3}, 0.1 \mathrm{~mol} / 1 \mathrm{~S} \mathrm{~S}_{2} \mathrm{O}_{3}{ }^{2-}$ 
In contrast to iron, zinc is soluble in ammoniacal solution, existing predominantly as zinc tetrammine, $\mathrm{Zn}\left(\mathrm{NH}_{3}\right)_{4}{ }^{2+}$, as shown in the zinc-ammonia-thiosulphate-water $\mathrm{E}_{\mathrm{h}}-\mathrm{pH}$ diagram, Figure 2.7. Without solution pre-treatment, zinc concurrently cements both copper and gold from solution ${ }^{[3,14]}$. The deposited copper will also cement gold from solution. By lowering the solution $\mathrm{pH}$ to 8 and using a minimal amount of zinc, some control over the amount of copper deposited from solution can be achieved ${ }^{[14]}$.

Zinc, being a relatively strong reducing agent, will also reduce thiosulphate to sulphide causing precipitation of relatively insoluble zinc sulphide, $\mathrm{ZnS}^{[3,14]}$.

$\mathrm{Zn}+\mathrm{S}_{2} \mathrm{O}_{3}{ }^{2-} \rightarrow \mathrm{ZnS} \downarrow+\mathrm{SO}_{3}{ }^{2-}$

The precipitation of zinc sulphide on the zinc particles has a marked deleterious effect on cementation $^{[20]}$.

The product of cementation will contain significant amounts of copper, zinc, and mixed sulphides. Since copper is a necessary catalyst for gold dissolution, its removal from recycled solution is undesirable. The introduction of zinc ions to solution is also undesirable since they have a demonstrated negative effect on gold leaching ${ }^{[3]}$. This is probably related to the preference of zinc to exist as zinc tetrammine, $\mathrm{Zn}\left(\mathrm{NH}_{3}\right)_{4}{ }^{2+}$, which consumes ammonia thereby affecting the mechanism of gold dissolution and reducing the solubility of copper.

\subsubsection{Copper Cementation of Gold}

Cementation of gold by copper is an important mechanism in cementing gold from thiosulphate solution whether the principal cementing agent is copper or iron or zinc. Copper metal selectively cements gold producing a relatively clean metal concentrate without introducing deleterious impurities into solution ${ }^{[2]}$. In fact, using metallic copper introduces copper ions into solution which is beneficial for leaching ${ }^{[1,2]}$. 
Lower $\mathrm{pHs}$, in the range of 7.5 to 8 , are beneficial for cementation performance. It is claimed that at higher $\mathrm{pHs}$ current efficiency decreases due to increased oxidation of copper in the formation copper-ammine complexes ${ }^{[1]}$.

\subsection{Theoretical Fundamentals of Cementation}

Cementation processes are heterogeneous systems in which one metal in solution is reduced by a sacrificial metal that dissolves as the reaction proceeds. The general form of the cementation reaction, where $\mathrm{N}$ is the more noble metal being reduced and $\mathrm{M}$ is the reductant metal, appears below:

$\frac{\mathrm{n}}{\mathrm{m}} \mathrm{N}^{\mathrm{m}+}+\mathrm{M} \rightarrow \frac{\mathrm{n}}{\mathrm{m}} \mathrm{N}+\mathrm{M}^{\mathrm{n}+}$

The standard electrode potential, $\mathrm{E}^{\circ}$, for the above reaction is related to the standard change in free energy, $\Delta \mathrm{G}^{\circ}$.

$E^{o}=-\frac{\Delta G^{\circ}}{n F}$

In order for the reaction to proceed it must have a positive reversible electrode potential, which can be calculated using the Nernst equation.

$E_{\text {rev }}=E^{\circ}-\frac{R T}{n F} \ln \left(\frac{a(N)^{\frac{n}{m}} a\left(M^{n+}\right)}{a\left(N^{m+}\right)^{\frac{n}{m}} a(M)}\right)$

Though the Nernst equation indicates whether or not the reaction is thermodynamically favoured it tells nothing of the actual rate of the reaction.

\subsubsection{Kinetics of Cementation Reactions}

All cementation reactions can be broken down into a series of physical steps, any of which can be rate controlling. Ignoring redeposition of the dissolving metal, the 
following five steps may be said to describe the chemical and mass transfer processes of a simple cementation reaction ${ }^{[21]}$.

1. Diffusion of the noble metal ion, $\mathrm{N}^{\mathrm{m}+}$, through the boundary layer to the double layer at the metal-solution interface.

2. Desolvation of the depositing metal ion and incorporation into the crystal lattice.

3. Conductance of electrons from the anodic site and transfer of electrons from the dissolving metal, $\mathrm{M}$, to the depositing metal ion, $\mathrm{N}^{\mathrm{m}+}$.

4. Release and solvation of the dissolving metal ion, $\mathrm{M}^{\mathrm{nt}}$.

5. Diffusion of the solvated metal ion, $\mathbf{M}^{\mathrm{n}+}$, through the boundary layer to the bulk electrolyte.

The above steps are represented schematically in Figure 2.8. If either step 1 or 5 is the slowest, the reaction is said to be under mass transfer control. If step 2,3 or 4 is the slowest then the reaction is under chemical control.

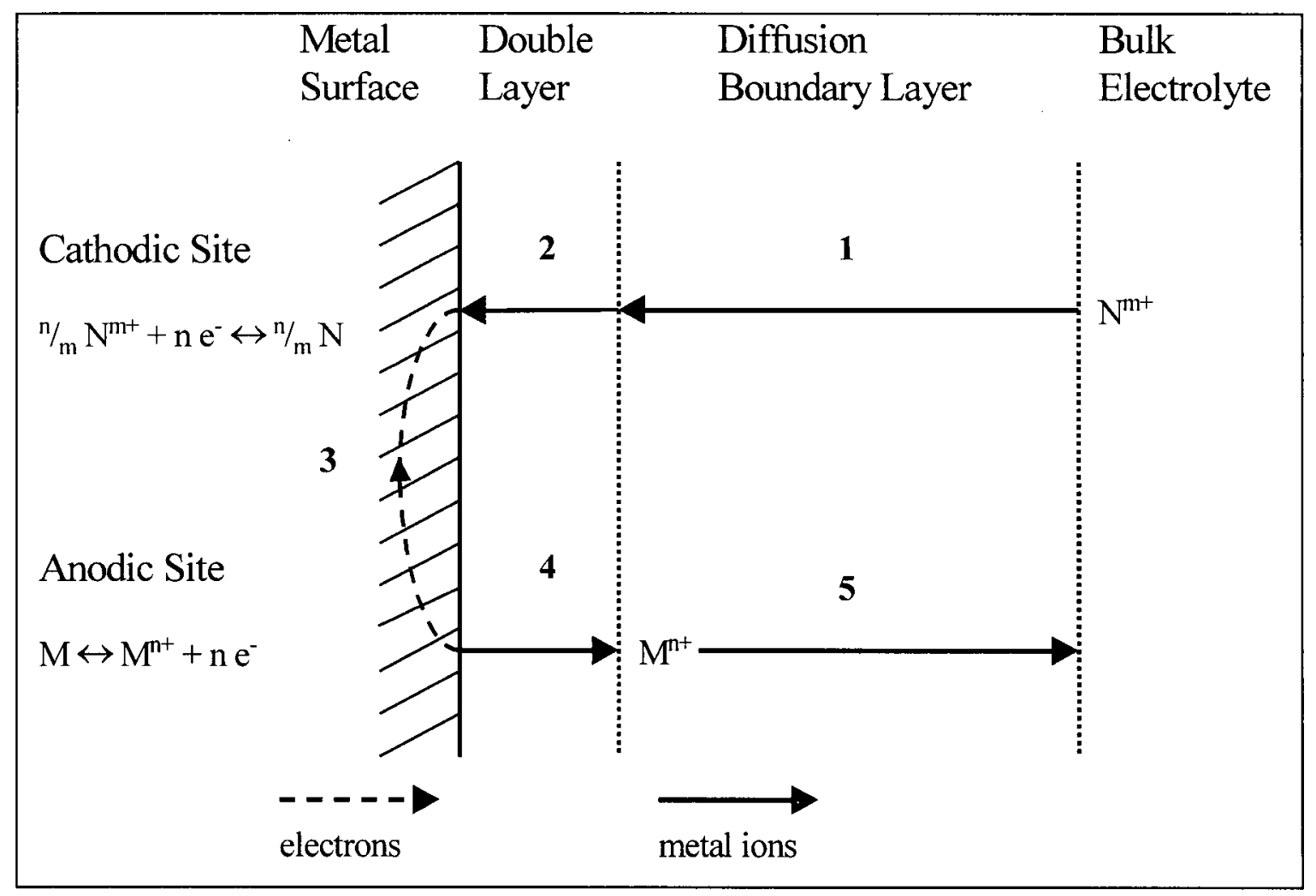

Figure 2.8: Physical Steps of a Simple Cementation Reaction 


\subsubsection{Chemical Rate Control in Cementation}

The general expression that describes the rate of a chemically controlled cementation reaction, i.e. controlled by step 2 or 4 , is presented below:

$\frac{\mathrm{dC}}{\mathrm{dt}}=-\mathrm{k}\left(\frac{\mathrm{A}}{\mathrm{V}}\right) \mathrm{C}^{\mathrm{n}}$

Most cementation reactions demonstrate first-order kinetics, i.e. $n=1^{[18]}$. Substituting for $\mathrm{n}$ and integrating equation 2.16 over a time period ' $t$ ', i.e. from $t=0$ to $t=t$, yields equation 2.17 .

$\ln \left(\frac{C_{t}}{C_{0}}\right)=-k_{1}\left(\frac{A}{V}\right) t$

This model is sometimes referred to as the 'linear' model since, when plotted using a semi-log scale, there is a straight-line relationship between $C_{t}$ and $t$. The magnitude of the rate constant, $\mathrm{k}_{1}$, is related to the fraction of molecules having sufficient energy to exceed the activation energy barrier, $\Delta \mathrm{G}^{*}$, which is given by Maxwell's distribution law.

$\mathrm{k}_{1}=\mathrm{k}_{0} \exp \left(-\frac{\Delta \mathrm{G}^{*}}{\mathrm{RT}}\right)$

Metals used in cementation reactions are usually good conductors and thus, the ohmic resistance in conductance of electrons is often considered to be insignificant ${ }^{[17]}$. Step 3 can, therefore, be discounted from being rate controlling allowing for the assumption that the anodic and cathodic half-cell reactions occur at the same potential, i.e. the mixed or corrosion potential, $\mathrm{E}_{\mathrm{m}}{ }^{[18]}$. The difference between the mixed potential and the reversible potential for a given half-cell reaction is the overpotential, $\eta$.

$\eta=E_{m}-E_{\text {rev }}$ 
The effect of an overpotential on the kinetics of a half-cell reaction is proportioned between accelerating the forward reaction, $\alpha \eta$, and retarding the reverse reaction, $(1-\alpha) \eta$. This polarisation effect is illustrated using a reaction co-ordinate diagram for the anodic dissolution reaction, Figure 2.9 (the change in free energy due to the overpotential, $\Delta G_{o p}$, is related to the overpotential through equation 2.14).

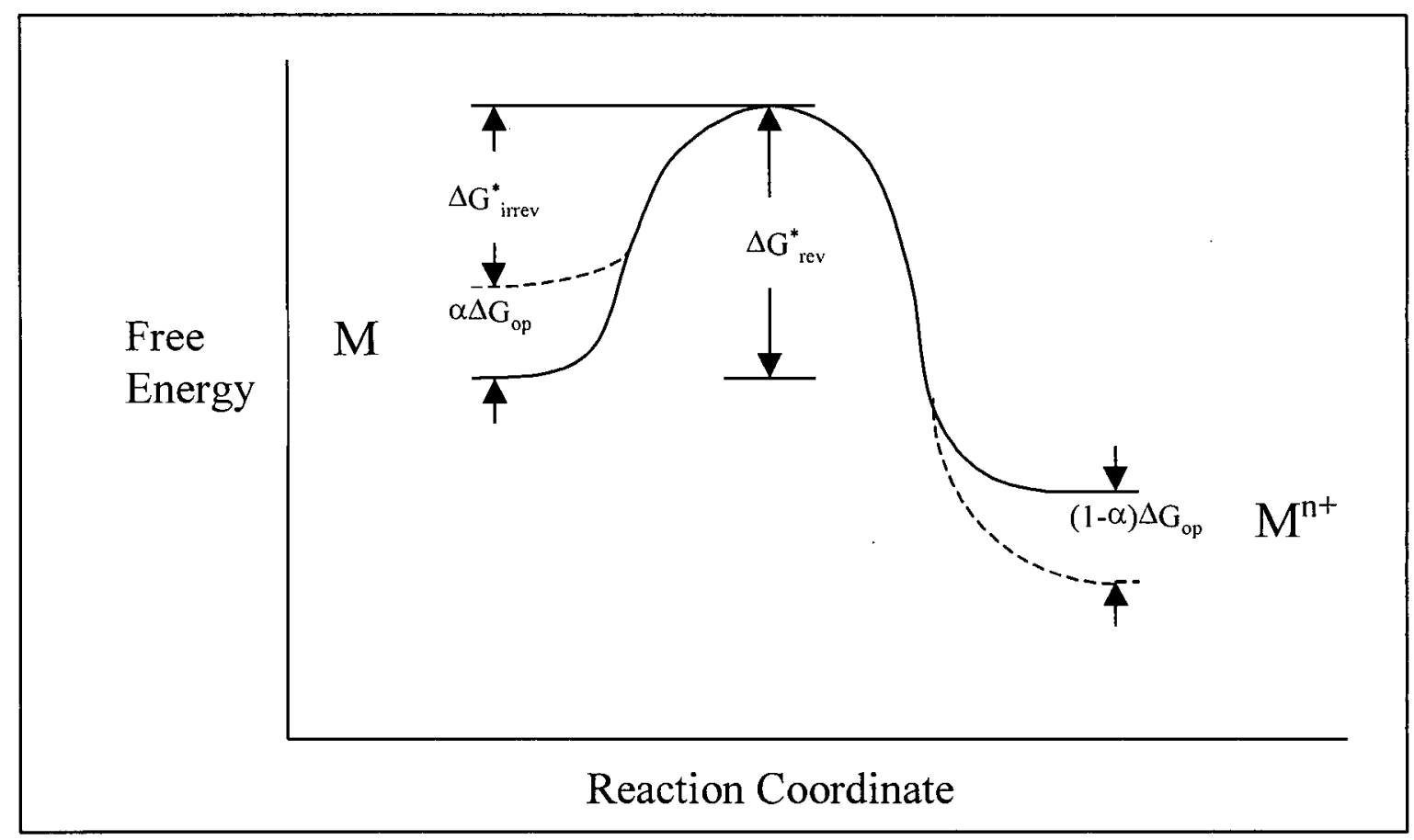

Figure 2.9: Reaction Co-ordinate Diagram of an Anodic Dissolution Reaction

Many cementation reactions have relatively large overpotentials and rarely approach equilibrium in practice ${ }^{[22]}$. Each half-cell reaction can, therefore, be treated as irreversible, i.e. occurring only in the forward direction.

$\mathrm{k}_{1}=\mathrm{k}_{0} \exp \left(-\frac{\Delta \mathrm{G}^{*}{ }_{\text {irrev }}}{\mathrm{RT}}\right)=\mathrm{k}_{0} \exp \left(\frac{\alpha \Delta \mathrm{G}_{\text {op }}}{\mathrm{RT}}-\frac{\Delta \mathrm{G}^{*}{ }_{\text {rev }}}{\mathrm{RT}}\right)=\mathrm{k}_{0} \exp \left(-\frac{\alpha \mathrm{nF} \eta}{\mathrm{RT}}\right) \exp \left(-\frac{\Delta \mathrm{G}^{*}{ }_{\text {rev }}}{\mathrm{RT}}\right)$

\subsubsection{Mass Transfer Control in Cementation}

Mathematical analysis of mass transfer processes in cementation begins with Fick's first law of diffusion, represented by equation 2.21 . 
$J=-D_{c}\left(\frac{\partial C}{\partial x}\right)$

It is convenient to approximate the reaction surface to be a flat plane. This allows for the assumption that concentration varies in only one direction, i.e. $\partial \mathrm{C} / \partial \mathrm{x}=\mathrm{dC} / \mathrm{dx}$. Since cementation reactions, typically, take place under well mixed but carefully controlled conditions it may also be assumed the boundary layer has a defined thickness, $\delta$, and that all resistance to mass transfer resides in this layer, i.e. $\mathrm{dx}=\delta$ and the bulk concentration of $\mathrm{C}$ is uniform outside the boundary layer. The remaining component of concentration gradient, $\mathrm{dC}$, is the difference in concentration of $\mathrm{C}$ between the bulk solution and the metal solution interface, i.e. $\mathrm{dC}=\mathrm{C}-\mathrm{C}^{\text {inter }}$. Since the co-ordinate system is fixed, equation 2.21 may be simplified to the following equation:

$\mathrm{J}=\frac{\mathrm{n}_{\mathrm{c}}}{\mathrm{A}}=-\mathrm{D}_{\mathrm{c}} \frac{\mathrm{C}-\mathrm{C}^{\mathrm{inter}}}{\delta}$

If the overall process is under mass transfer control, it is implicit that the chemical reactions are much faster than diffusion processes. It is, therefore, reasonable to assume that the interfacial concentration is relatively constant and independent of bulk concentration. By multiplying both sides of equation 2.22 by the ratio of the transport area to the total volume of solution, $A / V$, the term $n_{c} / V$ can be isolated. By inspection, this term describes the rate of change in bulk concentration of $\mathrm{C}$, i.e. $\mathrm{dC} / \mathrm{dt}$.

$\frac{\mathrm{n}_{\mathrm{c}}}{\mathrm{V}}=\frac{\mathrm{dC}}{\mathrm{dt}}=-\mathrm{D}_{\mathrm{c}}\left(\frac{\mathrm{A}}{\mathrm{V}}\right) \frac{\mathrm{C}-\mathrm{C}^{\text {inter }}}{\delta}$

Integrating equation 2.23 over a time period ' $t$ ', i.e. from $t=0$ to $t=t$, yields equation 2.24 .

$\ln \left(\frac{C_{t}-C^{\text {inter }}}{C_{0}-C^{\text {inter }}}\right)=-\frac{D_{c}}{\delta}\left(\frac{A}{V}\right) t$

In the case where $\mathrm{C}$ is the noble metal ion being deposited, then the concentration of $\mathrm{C}$ at the metal-solution interface approaches zero and equation 2.24 may be reduced to a 
simple first order rate equation with the term $D_{c} / \delta$ being analogous to a first order chemical rate constant, $\mathrm{k}_{1}$.

$\ln \left(\frac{C_{t}}{C_{0}}\right)=-\frac{D_{c}}{\delta}\left(\frac{A}{V}\right) t$

\subsection{Experimental Methods in Kinetic Studies of Cementation Systems}

The physical set-up and types of analyses in an experiment should be selected depending on the type of information desired, i.e. directly applicable empirical data or fundamental data. Different reductant metal geometries and methods of stirring provide specific hydrodynamic conditions that can be incorporated into mathematical models. Two unique geometries are powder (resembling an industrial process) and rotating disk (highly accurate fundamental approach). Most cementation studies are carried out in batch reactors. Stirring speed and temperature are variables commonly manipulated when attempting to determine the rate control regime. Analysis of the reductant substrate is also useful when characterising the type of rate control.

\subsubsection{Solution Analysis}

Consider again the general expression for a cementation reaction, where $\mathrm{N}$ is the more noble metal being reduced and $\mathrm{M}$ is the reductant metal.

$\frac{n}{m} N^{m+}+M \rightarrow \frac{n}{m} N+M^{n+}$

Provided there are no competing side-reactions, the kinetics of this system can be studied by measurement of the appearance of either $\mathrm{N}$ or $\mathrm{M}^{\mathrm{nt}}$ or the disappearance of $\mathrm{N}^{\mathrm{m}+}$ or $\mathrm{M}^{[21]}$. The simplest and most convenient method is measurement of the depletion of the noble metal ion, $\mathrm{N}^{\mathrm{m}+}$. This can usually be accomplished by one of a number of techniques, the selection of which depends on solution conditions and the concentration range of $\mathrm{N}^{\mathrm{m}+}$, including; colorimetry, polarography, specific ion electrodes, inductivelycoupled plasma spectroscopy, and atomic absorption spectroscopy. 


\subsubsection{Powder Cementation}

Most industrial cementation processes operate under vigorous mixing conditions near the limit of mass transport and introduce the active metal to solution in the form of a high surface area powder. Provided that a powder has a calculable surface area, e.g. is regularly shaped and is very closely sized or monosized or has a specified particle size distribution, then lab-scale experiments using the powder can be used to approximate industrial-scale cementation. Care must be taken when selecting a method of agitation since all stirrers will reach a limit of efficiency at which point higher stirring speeds will no longer lead to increased mass transport. In these solid-liquid mixing systems it is important to mix the solution at rates beyond the off-bottom suspension point of the coarsest particles since increasing mixer power beyond this point only marginally improves mass transport ${ }^{[23]}$. Under these well mixed conditions 'Film Theory', used in the derivation of equation 2.25 , can be used to mathematically model the mass transfer processes.

\subsubsection{Rotating Disk Electrode Cementation}

The use of rotating disk electrodes is one of the most popular methods in quantitative studies of cementation kinetics because of its high accuracy and reproducibility. The main feature of the rotating disk electrode is that it acts as a "uniformly accessible surface", which means that mass transport to the surface is uniform ${ }^{[24]}$. The flow of solution across the electrode surface is laminar creating a boundary layer of constant thickness up to a Reynolds number of approximately $10^{5[21]}$. The equation describing the relationship between time and the bulk concentration of a species, $\mathrm{C}$, being deposited on the electrode surface, is given below:

$\ln \left(\frac{\mathrm{C}_{\mathrm{t}}}{\mathrm{C}_{0}}\right)=-\frac{0.620 \mathrm{D}_{\mathrm{c}}^{2 / 3} \omega^{1 / 2}}{v^{1 / 6}}\left(\frac{\mathrm{A}}{\mathrm{V}_{\text {avg }}}\right) \mathrm{t}$

The theoretical derivation of the equations describing the hydrodynamics of the rotating disk system were established by Levich ${ }^{[25]}$. 


\subsubsection{Analysis of the Reductant Substrate}

The nature and appearance of deposits on the reductant surface can tell a great deal about the conditions under which they were formed. Optical and electron microscopes are commonly used to examine the morphology of deposits. In general, dendritic or botryoidal deposits are characteristic of diffusion controlled cementation, while smooth, tight, coherent deposits are typically formed under conditions of chemical control. Scanning electron microscopes offer excellent magnification and, since the emission $\mathrm{X}$ rays excite certain fluorescent $\mathrm{X}$-rays in elements, when equipped with a detector the scanning electron microscope can collect information about the elements present in a sample ${ }^{[26]}$. Another technique used to determine the structure of crystalline deposits is Xray diffraction.

\subsubsection{Determination of Activation Energy}

The effect of temperature on the magnitude of a reaction rate constant is described by the Arrhenius equation.

$\ln \left(\mathrm{k}_{1}\right) \propto \frac{1}{\mathrm{~T}}\left(-\frac{\Delta \mathrm{G}^{*}}{\mathrm{R}}\right)$

By performing the same experiment at several temperatures and measuring the rate constant as a function of temperature, an Arrhenius plot may be generated. The plot should be a straight-line relationship between the natural logarithm of the experimentally determined rate constants and the reciprocal of the absolute temperatures. By inspection, the slope of the line is the activation energy divided by the universal gas constant. The activation energy, $\Delta \mathrm{G}^{*}$, for chemically controlled processes usually exceeds $40 \mathrm{~kJ} / \mathrm{mol}$ while for diffusion controlled processes is less than $20 \mathrm{~kJ} / \mathrm{mol}^{[27]}$.

\subsection{Factorial Design}

An efficient method for designing an experiment in order to reduce the number of runs and simplify the subsequent treatment of data is factorial design ${ }^{[28]}$. The simplest 
factorial design is two-level, or high-low, factorial design, in which each variable being studied has only two distinct settings. These settings are coded, +1 for the higher setting and -1 for the lower setting. Consider a system for which the effects of three factors; A, $\mathrm{B}$, and $\mathrm{C}$, are being studied. The general equation which relates a measured observation, OBS, to a linear combination of the mean response, $\mu$, and the effects of the individual factors and their interaction effects is presented below (where $a, b$ and $c$ can be -1 or 1 ).

$\mathrm{OBS}_{(\mathrm{abc})}=\mu+\mathrm{A} \times \mathrm{a}+\mathrm{B} \times \mathrm{b}+\mathrm{C} \times \mathrm{c}+\mathrm{AB} \times(\mathrm{a} \times \mathrm{b})+\mathrm{AC} \times(\mathrm{a} \times \mathrm{c})+\mathrm{BC} \times(\mathrm{b} \times \mathrm{c})+\mathrm{ABC} \times(\mathrm{a} \times \mathrm{b} \times \mathrm{c})$

The minimum number of runs, which include all possible combinations of the levels for all three factors, is eight, i.e. $2^{3}$. Performing this number of runs generates eight distinct observed responses which create eight equations with the eight unknowns; the mean response and seven main and interaction effect parameters. This concept is presented in matrix form in Figure 2.10.

Coefficient Matrix
\begin{tabular}{|c|c|c|c|c|c|c|c|c|c|c|}
\hline Run & $(1)$ & $\mathrm{a}$ & $\mathrm{b}$ & $\mathrm{c}$ & $\mathrm{a} \times \mathrm{b}$ & $\mathrm{a} \times \mathrm{c}$ & $\mathrm{b} \times \mathrm{c}$ & $\mathrm{a} \times \mathrm{b} \times \mathrm{c}$ & & Yield \\
\hline 1 & 1 & 1 & 1 & 1 & 1 & 1 & 1 & 1 & $\mu$ & $\mathrm{OBS}_{(111)}$ \\
\hline 2 & 1 & -1 & 1 & 1 & -1 & -1 & 1 & -1 & $\mathrm{~A}$ & $\mathrm{OBS}_{(-111)}$ \\
\hline 3 & 1 & 1 & -1 & 1 & -1 & 1 & -1 & -1 & $\mathrm{~B}$ & $\mathrm{OBS}_{(1-11)}$ \\
\hline 4 & 1 & 1 & 1 & -1 & 1 & -1 & -1 & -1 & $\mathrm{C}$ & $\mathrm{OBS}_{(11-1)}$ \\
\hline 5 & 1 & -1 & -1 & 1 & 1 & -1 & -1 & 1 & $\mathrm{AB}$ & $\mathrm{OBS}_{(-1-11)}$ \\
\hline 6 & 1 & -1 & 1 & -1 & -1 & 1 & -1 & 1 & $\mathrm{AC}$ & $\mathrm{OBS}_{(-11-1)}$ \\
\hline 7 & 1 & 1 & -1 & -1 & -1 & -1 & 1 & 1 & $\mathrm{BC}$ & $\mathrm{OBS}_{(1-1-1)}$ \\
\hline 8 & 1 & -1 & -1 & -1 & 1 & 1 & 1 & -1 & $\mathrm{ABC}$ & $\mathrm{OBS}_{(-1-1-1)}$ \\
\hline
\end{tabular}

Figure 2.10: Matrix Form of a Three Factor, High-Low, Factorial Design

Once the values for the effects are solved for, a popular first step in determining which effects are significant is construction of a normal probability plot ${ }^{[29]}$. First, the effects are ranked from smallest to largest. These ordered effects are then plotted against their observed cumulative frequency, $(\mathrm{j}-0.5) / \mathrm{n}$ (where $\mathrm{j}$ varies from 1 to $\mathrm{n}$ and $\mathrm{n}$ is the number of degrees of freedom). This relation is a straight line with slope $1 / \mathrm{n}$. If a plotted point deviates significantly from the straight line, then the effect is not random and, consequently, is not appropriately described by the normal distribution model. The initial evaluation of those effects that deviate sufficiently from the normal distribution model to 
be considered significant is subjective. Once selected, however, the significance of each of the selected variables can be evaluated using a t-test. In addition, since the remaining insignificant effects should be distributed normally about the mean, the appropriateness of eliminating the presumed significant effect(s) from the model may be tested using a chi-square goodness of fit test ${ }^{[30]}$.

In cases where there are a large number of variables to be studied, by sacrificing information about high-order interactions, the use of a fractional design can further reduce the number of runs. This type of experimental design is often employed in screening experiments where it is likely that many of the factors considered have little or no effect on the respons $\mathrm{e}^{[31]}$. The principle upon which the number of runs can be reduced is known as 'aliasing of effects'. The concept of 'aliasing of effects' is best illustrated with an example. Consider a two-level factorial experiment with five variables; A, B, C, D, and E. All first and second order effects may be estimated by running half of the full factorial design, i.e. $2^{5-1}$ or 16 runs. One of two possible experimental designs is presented in matrix form in Figure 2.11.

Coefficient Matrix

Effect Vector

\begin{tabular}{|c|c|c|c|c|c|c|c|c|c|c|c|c|c|c|c|c|c|}
\hline Run & $\mathrm{a}$ & $\mathrm{b}$ & $\mathrm{c}$ & $\mathrm{d}$ & $\mathrm{e}$ & $\mathrm{abc}$ & $\mathrm{abd}$ & $\mathrm{abe}$ & $\mathrm{acd}$ & ace & ade & $\mathrm{bcd}$ & $\mathrm{bce}$ & $\mathrm{bde}$ & $\mathrm{cde}$ & $\mathrm{abcde}$ & \\
\hline 1 & 1 & -1 & -1 & -1 & -1 & 1 & 1 & 1 & 1 & 1 & 1 & -1 & -1 & -1 & -1 & 1 & $\mathrm{~A}$ \\
\hline 2 & -1 & 1 & -1 & -1 & -1 & 1 & 1 & 1 & -1 & -1 & -1 & 1 & 1 & 1 & -1 & 1 & $\mathrm{~B}$ \\
\hline 3 & 1 & -1 & 1 & -1 & -1 & 1 & -1 & -1 & 1 & 1 & -1 & 1 & 1 & -1 & 1 & 1 & $\mathrm{C}$ \\
\hline 4 & -1 & -1 & -1 & 1 & -1 & -1 & 1 & -1 & 1 & -1 & 1 & 1 & -1 & 1 & 1 & 1 & $\mathrm{D}$ \\
\hline 5 & -1 & -1 & -1 & -1 & 1 & -1 & -1 & 1 & -1 & 1 & 1 & -1 & 1 & 1 & 1 & 1 & $\mathrm{E}$ \\
\hline 6 & 1 & 1 & 1 & -1 & -1 & 1 & -1 & -1 & -1 & -1 & 1 & -1 & -1 & 1 & 1 & 1 & ABC \\
\hline 7 & 1 & 1 & -1 & 1 & -1 & -1 & 1 & -1 & -1 & 1 & -1 & -1 & 1 & -1 & 1 & 1 & ABD \\
\hline 8 & 1 & 1 & -1 & -1 & 1 & -1 & -1 & 1 & 1 & -1 & -1 & 1 & -1 & -1 & 1 & 1 & ABE \\
\hline 9 & 1 & -1 & 1 & 1 & -1 & -1 & -1 & 1 & 1 & -1 & -1 & -1 & 1 & 1 & -1 & 1 & ACD \\
\hline 10 & 1 & -1 & 1 & -1 & 1 & -1 & 1 & -1 & -1 & 1 & -1 & 1 & -1 & 1 & -1 & 1 & ACE \\
\hline 11 & 1 & -1 & -1 & 1 & 1 & 1 & -1 & -1 & -1 & -1 & 1 & 1 & 1 & -1 & -1 & 1 & ADE \\
\hline 12 & -1 & 1 & 1 & 1 & -1 & -1 & -1 & 1 & -1 & 1 & 1 & 1 & -1 & -1 & -1 & 1 & BCD \\
\hline 13 & -1 & 1 & 1 & -1 & 1 & -1 & 1 & -1 & 1 & -1 & 1 & -1 & 1 & -1 & -1 & 1 & BCE \\
\hline 14 & -1 & 1 & -1 & 1 & 1 & 1 & -1 & -1 & 1 & 1 & -1 & -1 & -1 & 1 & -1 & 1 & BDE \\
\hline 15 & -1 & -1 & 1 & 1 & 1 & 1 & 1 & 1 & -1 & -1 & -1 & -1 & -1 & -1 & 1 & 1 & CDE \\
\hline 16 & 1 & 1 & 1 & 1 & 1 & 1 & 1 & 1 & 1 & 1 & 1 & 1 & 1 & 1 & 1 & 1 & ABCDE \\
\hline
\end{tabular}

Figure 2.11: Matrix Form of a Five Factor, High-Low, Fractional Factorial Design 
Solving for the third order interaction parameters is misleading since these effects are aliased with second order interactions, i.e. the third order interaction parameter is a combination of second and third order interaction effects. Third order interaction effects are, in fact, assumed to negligible leaving only the associated second order interaction effects. Similarly, the first order effect parameters, though solved for directly, are aliased with fourth order interactions which are assumed to be negligible. A complete list of all aliased effects in a $2^{5-1}$ experimental design is presented below:
$\mathrm{AB}$ and $\mathrm{CDE} \quad \mathrm{AC}$ and $\mathrm{BDE} \quad \mathrm{AD}$ and $\mathrm{BCE} \quad \mathrm{AE}$ and $\mathrm{BCD} \quad \mathrm{BC}$ and $\mathrm{ADE} \quad \mathrm{BD}$ and $\mathrm{ACE}$
$\mathrm{BE}$ and $\mathrm{ACD} \quad \mathrm{CD}$ and $\mathrm{ABE} \quad \mathrm{CE}$ and $\mathrm{ABD} \quad \mathrm{DE}$ and $\mathrm{ABC} \quad \mathrm{A}$ and $\mathrm{BCDE} \quad \mathrm{B}$ and $\mathrm{ACDE}$ $\mathrm{C}$ and $\mathrm{ABDE} \quad \mathrm{D}$ and $\mathrm{ABCE} \quad \mathrm{E}$ and $\mathrm{ABCD} \mu$ and $\mathrm{ABCDE}$

\subsection{Summary}

Solution $\mathrm{pH} / \mathrm{ammonia}$ concentration, copper concentration, thiosulphate concentration, sulphite concentration, and temperature each play important roles in ammoniacal thiosulphate leaching of gold. Cementation of gold using metallic copper seems to be the most promising method for recovering gold from thiosulphate leach solutions. Since thiosulphate leaching is, as yet, commercially undeveloped, there has been little attention paid to how these solution characteristics would affect the kinetics of gold recovery during a cementation stage. Even when other less noble cementing agents are used, the mechanism of gold cementing onto copper plays an important role in gold recovery. The aforementioned five variables, commonly manipulated in leach studies, could potentially have positive, negative or insignificant effects on cementation kinetics when using copper as the cementing agent. In an industrial operation that recycles leach solution this type of information is essential when establishing whether to add a reagent or change solution temperature before or after the gold recovery stage.

The theory and experimental methods for studying the kinetics of cementation systems are well established. By observing and quantitatively evaluating cementation kinetics under different solution conditions using a factorial design experiment, individual variable effects as well as interactive effects can be determined. It is, therefore, the 
objective of this work to establish how initial $\mathrm{pH} / \mathrm{ammonia}$ concentration, copper concentration, thiosulphate concentration, sulphite concentration, temperature, and their interactive effects affect the kinetics of copper cementation of gold from thiosulphate solution. The regime of rate control for this cementation system will also be established. 


\section{Experimental Approach}

Cementation experiments were carried out in one of two batch reactors, a reactor for studying powder cementation systems and another that used rotating disk electrodes. Since there was no source of gold bearing thiosulphate leach solutions from an industrial operation, the solutions used in the cementation experiments were prepared using high purity reagents in the concentration ranges typical of leach studies found in literature. Each experiment tracked the depletion of gold from solution. The corresponding rate constant was determined and used as the basis for comparison of cementation performance between experiments carried out under different conditions. Initial experiments using the powder cementation apparatus were designed to establish the degree of reproducibility of experiments performed under identical conditions and to determine the rate control regime of the gold cementation process. Later experiments focused on determining how variations in temperature, $\mathrm{pH} / \mathrm{ammonia}$ concentration, initial copper concentration, initial thiosulphate concentration, and initial sulphite concentration, affect the relative performance of copper cementation of gold. Experiments performed using the rotating disk electrode apparatus were designed to more precisely establish the rate control regime of the gold cementation reaction of the gold-thiosulphate complex on copper.

\subsection{Powder Cementation Experiments}

\section{Cementation Reactor}

The batch reactor, in which the powder cementation experiments were carried out, is represented schematically in Figure 3.1. The reactor consisted of a 4 litre glass vessel with a removable acrylic lid. The solutions were stirred by a stainless steel shaft and impeller connected to a variable speed DC motor. An immersion heater, connected to a PID controller, heated the solutions. The entry of oxygen into the reactor was minimised by maintaining a positive pressure of nitrogen gas via a tube inserted into the top of the reactor. A gas flowmeter precisely controlled the flow of nitrogen gas into the reactor. 
Solution samples were drawn out of the top of the reactor, via a sampling port, using plastic syringes. While not is use, the sampling port was corked with a rubber stopper.

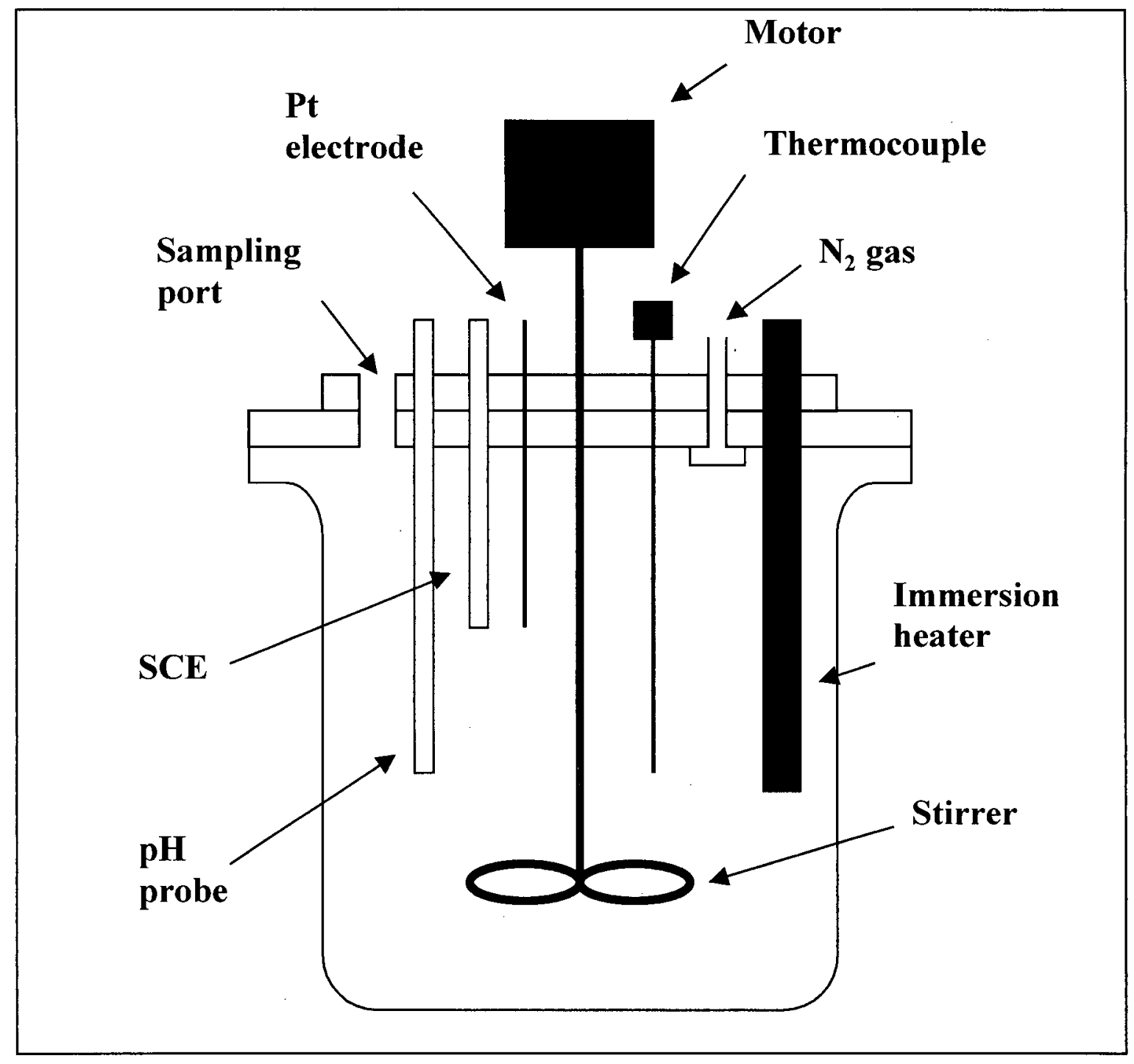

Figure 3.1: Powder Cementation Reactor

\section{Reagents}

The copper powder used, obtained from Cerac - Pure Advanced Specialty Inorganics, was $99.5 \%$ pure and sized between 100 and 200 mesh. The inorganic salts used in the preparation of the different solutions were; anhydrous sodium sulphite, $\mathrm{Na}_{2} \mathrm{SO}_{3}$, ammonium thiosulphate, $\left(\mathrm{NH}_{4}\right)_{2} \mathrm{~S}_{2} \mathrm{O}_{3}$, ammonium sulphate, $\left(\mathrm{NH}_{4}\right)_{2} \mathrm{SO}_{4}$, and copper sulphate, $\mathrm{CuSO}_{4} .5 \mathrm{H}_{2} \mathrm{O}$. Ammonia was also added as stock concentrated ammonium 
hydroxide, $30 \% \mathrm{NH}_{3}$. So as not to significantly alter the total volume of solutions, any required $\mathrm{pH}$ adjustment was made by dropwise addition of concentrated sodium hydroxide solution or concentrated sulphuric acid. Gold was added to solution as stock $1000 \mathrm{ppm}$ Au solution, the procedure for the preparation of which appears in Appendix A. When trivalent gold, $\mathrm{AuCl}_{4}{ }^{-}$, is mixed with sulphite and thiosulphate, it is immediately reduced to monovalent gold, $\mathrm{Au}\left(\mathrm{S}_{2} \mathrm{O}_{3}\right)_{2}{ }^{3-[32]}$.

\section{Analyses}

Each solution sample was analysed for gold content by atomic absorption spectroscopy (AAS). Selected solution samples were analysed for thiosulphate content according to the procedure outlined in Appendix $\mathrm{B}^{[33]}$. The total ammonia content of selected solution samples was determined using a procedure, outlined in Appendix C, which was modified from Vogel's textbook of quantitative chemical analysis ${ }^{[34]}$. Crystalline substances formed on the copper powder residues were identified by X-ray diffraction. A scanning electron microscope (SEM) was also used to examine the morphology as well as elemental composition of deposits on selected copper powder residues.

\subsubsection{Experiments to Establish Reproducibility and Rate Control Regime}

Five experiments were performed under identical conditions in order to establish the degree of reproducibility of experiments using the powder cementation apparatus. Table 3.1 summarises the initial solution conditions for the five experimental runs.

Table 3.1: Solution Conditions for Reproducibility Experiments

\begin{tabular}{|c|c|c|c|c|c|}
\hline $\begin{array}{c}\text { Temperature } \\
\left({ }^{\circ} \mathrm{C}\right)\end{array}$ & $\begin{array}{c}{\left[\mathrm{S}_{2} \mathrm{O}_{3}{ }^{2-}\right]} \\
(\mathrm{mol} / \mathrm{l})\end{array}$ & $\begin{array}{c}{\left[\mathrm{SO}_{3}{ }^{2-}\right]} \\
(\mathrm{mol} / 1)\end{array}$ & $\begin{array}{c}{\left[\mathrm{Cu}^{2+}\right]} \\
(\mathrm{g} / \mathrm{l})\end{array}$ & $\begin{array}{c}\left(\mathrm{NH}_{3}\right)_{\text {total }} \\
(\mathrm{mol} / 1)\end{array}$ & $\begin{array}{c}{\left[\mathrm{Au}^{+}\right]} \\
(\mathrm{ppm})\end{array}$ \\
\hline 50 & 0.1 & 0.1 & 1.0 & 0.73 & 13.3 \\
\hline
\end{tabular}

Each 3.75 litre solution underwent 30 minutes of conditioning, to remove dissolved oxygen, during which the solution was slowly stirred and heated to the set temperature under a nitrogen gas atmosphere. At time 0 , the rotation speed of the impeller was raised to $1250 \mathrm{rpm}$ and 5.00 grams of copper powder was added via the sampling port. Solution 
samples, for AAS analysis, were taken using $25 \mathrm{ml}$ plastic syringes after 1, 5, 10, 15, 20, $30,45,60$, and 90 minutes. Immediately after sampling, the syringes were fitted with $0.22 \mu \mathrm{m}$ nylon filters and the cementing agent was filtered out, thereby, stopping the reaction. The $\mathrm{pH}$ and solution potential were recorded for each sample. After 90 minutes, the solutions were filtered and the copper powder residues collected and dried at $50^{\circ} \mathrm{C}$ in a vacuum oven for 24 hours.

The initial experiments performed to establish the rate control regime of the gold cementation reaction were conducted using the identical solution conditions and procedures as those of the experiments testing reproducibility, with only the temperature being varied. The different temperatures at which the experiments were performed were $18,31,40,50$, and $60^{\circ} \mathrm{C}$.

\subsubsection{Fractional Factorial Design Experiment}

The effects of temperature, $\mathrm{pH} / \mathrm{ammonia}$ concentration, initial copper concentration, initial thiosulphate concentration, and initial sulphite concentration were studied using a

high-low, $2^{5-1}$ fractional factorial design experiment. This design was selected because of the large number of variables and the lack of knowledge of the importance of any one variable with respect to gold cementation performance. The procedures for solution conditioning, sampling, and data recording were the same as those described in section 3.1.1. The time intervals between samples were $1,2,5,10,15,20,30,45$, and 60 minutes. The high and low values for each variable are indicated in Table 3.2. 
Table 3.2: Experimental Design Layout for the Factorial Design Experiment

\begin{tabular}{|c|c|c|c|c|c|c|}
\hline Run & Standard & $\begin{array}{c}\text { Temp. } \\
\left({ }^{\circ} \mathrm{C}\right)\end{array}$ & $\begin{array}{c}{\left[\mathrm{S}_{2} \mathrm{O}_{3}{ }^{2-}\right]} \\
(\mathrm{mol} / 1)\end{array}$ & $\begin{array}{c}{\left[\mathrm{SO}_{3}{ }^{2-}\right]} \\
(\mathrm{mol} / 1)\end{array}$ & $\begin{array}{c}{\left[\mathrm{Cu}^{2+}\right]} \\
(\mathrm{g} / \mathrm{l})\end{array}$ & $\begin{array}{c}\left(\mathrm{NH}_{3}\right)_{\text {total }} \\
(\mathrm{mol} / \mathrm{l})\end{array}$ \\
\hline 1 & 6 & 50 & 0.036 & 0.100 & 0.1 & 0.20 \\
\hline 2 & 2 & 30 & 0.036 & 0.000 & 0.1 & 0.20 \\
\hline 3 & 16 & 50 & 0.100 & 0.100 & 0.1 & 0.73 \\
\hline 4 & 4 & 50 & 0.100 & 0.000 & 0.1 & 0.20 \\
\hline 5 & 9 & 30 & 0.036 & 0.000 & 0.0 & 0.73 \\
\hline 6 & 7 & 50 & 0.100 & 0.100 & 0.0 & 0.20 \\
\hline 7 & 11 & 50 & 0.100 & 0.000 & 0.0 & 0.73 \\
\hline 8 & 12 & 30 & 0.100 & 0.000 & 0.1 & 0.73 \\
\hline 9 & 8 & 30 & 0.100 & 0.100 & 0.1 & 0.20 \\
\hline 10 & 14 & 30 & 0.036 & 0.100 & 0.1 & 0.73 \\
\hline 11 & 15 & 30 & 0.100 & 0.100 & 0.0 & 0.73 \\
\hline 12 & 5 & 30 & 0.036 & 0.100 & 0.0 & 0.20 \\
\hline 13 & 1 & 50 & 0.036 & 0.000 & 0.0 & 0.20 \\
\hline 14 & 10 & 50 & 0.036 & 0.000 & 0.1 & 0.73 \\
\hline 15 & 3 & 30 & 0.100 & 0.000 & 0.0 & 0.20 \\
\hline 16 & 13 & 50 & 0.036 & 0.100 & 0.0 & 0.73 \\
\hline
\end{tabular}

Due to wide variations in solution conditions, special care had to be taken to ensure that the $\mathrm{pH}$ varied between only two values corresponding to the high and low ammonia conditions. In the solutions containing high ammonia, the $\mathrm{pH}$ was governed by the ammonia/ammonium buffer system. In order to ensure that the $\mathrm{pH}$ of these solutions was always $9.6 \pm 0.3$, appropriate additions of ammonium thiosulphate, ammonium sulphate, and ammonium hydroxide, were made such that the amounts of ammonia and ammonium initially added to solution always corresponded to concentrations of $0.53 \mathrm{~mol} / 1$ and 0.20 $\mathrm{mol} / \mathrm{l}$, respectively. The variance in $\mathrm{pH}$ was due, in large part, to the dependence of $\mathrm{pH}$ on solution temperature, e.g. the $\mathrm{pH}$ was lower at the higher temperature and vice versa. This effect is evident upon examination of the standard change in enthalpy, $-52.2 \mathrm{~kJ} / \mathrm{mol}$, for the ammonia/ammonium equilibrium reaction, equation 3.1.

$\mathrm{NH}_{3}+\mathrm{H}^{+} \leftrightarrow \mathrm{NH}_{4}^{+}$

When low ammonia was combined with high sulphite, the $\mathrm{pH}$ was governed by the sulphite/bisulphite buffer system resulting in a $\mathrm{pH}$ of $7.4 \pm 0.1$. The $\mathrm{pH}$ of this reaction, 
represented by equation 3.2 , is much less dependent on temperature, having a standard change in enthalpy of only $9.3 \mathrm{~kJ} / \mathrm{mol}$.

$\mathrm{SO}_{3}{ }^{2-}+\mathrm{H}^{+} \leftrightarrow \mathrm{HSO}_{3}^{-}$

In the unbuffered solutions where low sulphite was combined with low ammonia, stock concentrated sodium hydroxide was added to raise the $\mathrm{pH}$ to 7.4.

\subsection{Rotating Disk Electrode Experiments}

\section{Cementation Reactor}

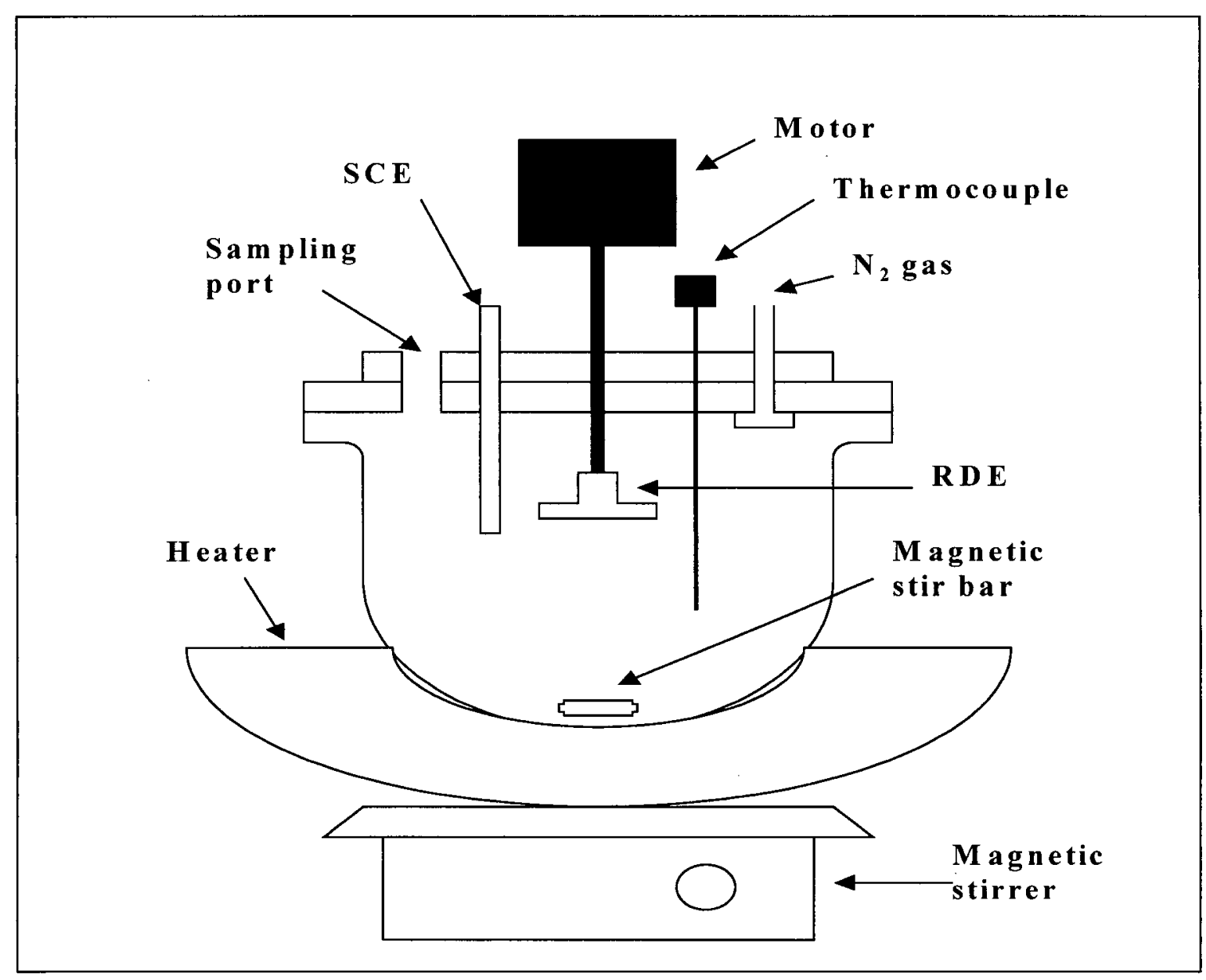

Figure 3.2: RDE Cementation Set-up 
The reactor used for the rotating disk electrode experiments is illustrated schematically in Figure 3.2. The reactor vessel was a 2 litre glass bell-jar with an acrylic lid. The acrylic lid contained holes for sampling and instrumentation. As illustrated in Figure 3.3, various RDEs could be screwed onto the end of a stainless steel shaft that was threaded at one end. The shaft and electrode assembly was turned by a variable speed DC motor. Measurements of potential on the copper electrodes were made between the shaft of the electrode assembly and a saturated calomel electrode in solution. A heating mantle, connected to a PID controller, heated the solutions. During solution conditioning, the solutions were stirred by a magnetic stirrer.

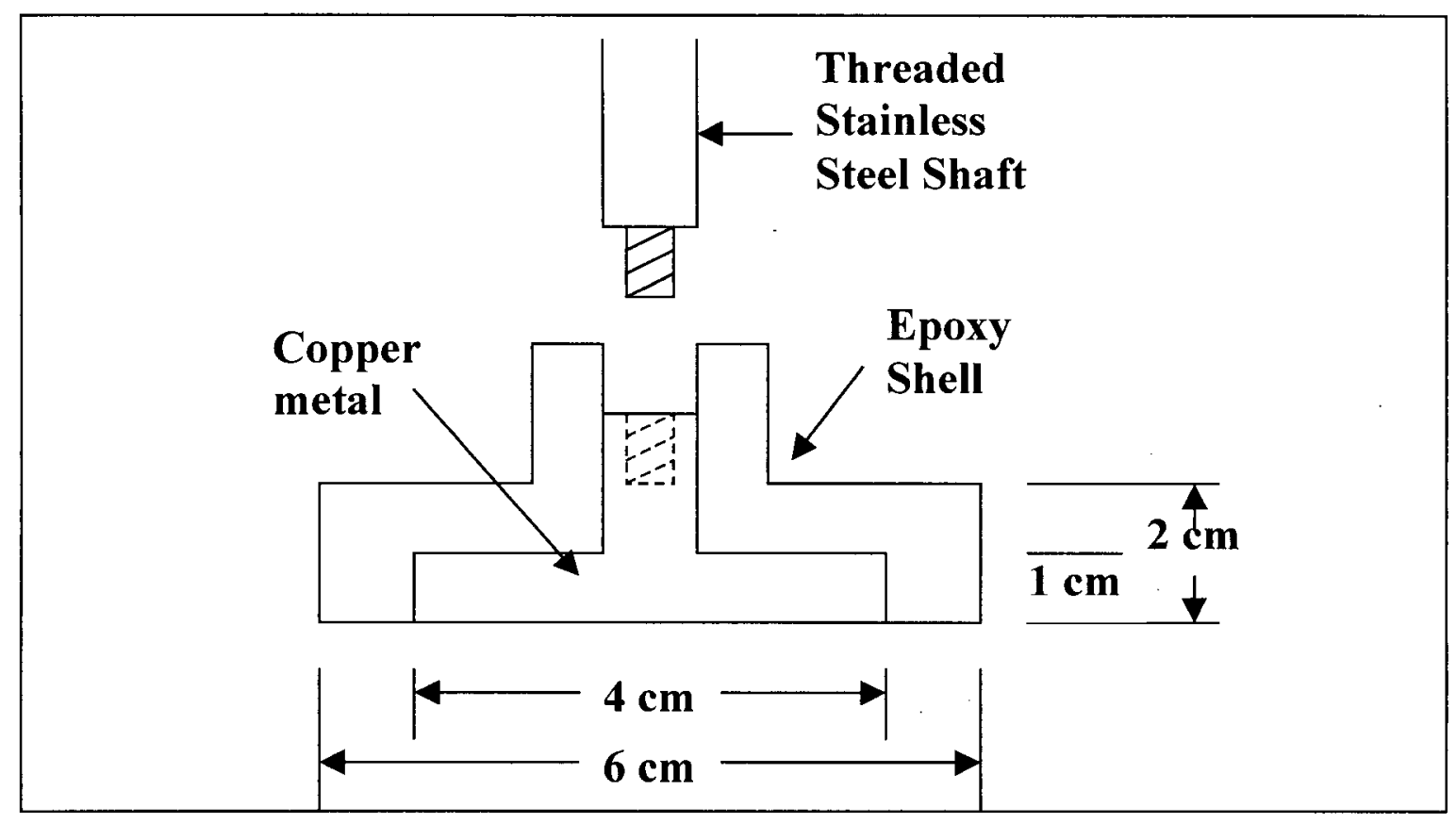

Figure 3.3: Shaft and Rotating Disk Electrode Assembly

\section{Reagents}

The copper metal from which the rotating disk electrodes were fabricated was $99.9 \%$ pure. In order to reduce the total amount of ammonia, thiosulphate was added to solution as sodium thiosulphate instead of ammonium thiosulphate. A relatively high $\mathrm{pH}$ was achieved by using stock concentrated ammonia as the sole source of ammonia. Gold was introduced to solution by adding stock $1000 \mathrm{ppm}$ Au solution. 


\section{Analyses}

Solution samples were analysed for gold content by atomic absorption spectroscopy.

\section{Experiments}

The experiments using the rotating disk electrode apparatus were designed to establish the rate control regime of the cementation reaction of the gold thiosulphate complex onto metallic copper. In order to ensure that gold in solution would exist, predominantly, as the gold-thiosulphate complex, $\mathrm{Au}\left(\mathrm{S}_{2} \mathrm{O}_{3}\right)_{2}{ }^{3-}$, as opposed to the gold-ammine complex, $\mathrm{Au}\left(\mathrm{NH}_{3}\right)_{2}{ }^{+}$, the concentration of thiosulphate was increased while the total concentration of ammonia was decreased relative to the powder cementation experiments. No copper or sulphite salts were added in order to eliminate any interfering effects they may have. The experimental conditions for the six experiments using the RDE apparatus are summarised in Table 3.3.

Table 3.3: Experimental Conditions of RDE Experiments. Initial Conditions: 12.5 ppm $\mathrm{Au}, 0.32 \mathrm{~mol} / 1 \mathrm{NH}_{3}(\mathrm{pH} 10.1), 0.2 \mathrm{~mol} / 1 \mathrm{~S}_{2} \mathrm{O}_{3}{ }^{2-}, \mathrm{V}_{\text {avg }} 985 \mathrm{ml}$

\begin{tabular}{|c|c|c|c|c|c|c|}
\hline $\begin{array}{c}\text { Temp. } \\
\left({ }^{\circ} \mathrm{C}\right)\end{array}$ & $\begin{array}{c}\phi \mathrm{Cu} \\
(\mathrm{cm})\end{array}$ & $\begin{array}{c}\phi \text { Disk } \\
(\mathrm{cm})\end{array}$ & $\begin{array}{c}\omega \\
(\mathrm{rad} / \mathrm{s})\end{array}$ & $\begin{array}{c}v^{*} \\
\left(\mathrm{~cm}^{2} / \mathrm{s} \times 10^{-2}\right)\end{array}$ & $\begin{array}{c}\mathrm{R}_{\mathrm{e}} \text { at Cu edge* } \\
\times 10^{4}\end{array}$ & $\begin{array}{c}\mathrm{R}_{\mathrm{e}} \text { at disk edge* } \\
\times 10^{4}\end{array}$ \\
\hline 22 & 3.720 & 5.855 & 45.24 & 0.957 & 1.64 & 4.05 \\
\hline 35 & 3.800 & 5.825 & 44.82 & 0.719 & 2.25 & 5.29 \\
\hline 35 & 3.800 & 5.825 & 45.66 & 0.719 & 2.29 & 5.39 \\
\hline 35 & 3.720 & 5.855 & 93.93 & 0.719 & 4.52 & 11.2 \\
\hline 35 & 3.745 & 6.035 & 70.37 & 0.719 & 3.43 & 8.91 \\
\hline 50 & 3.700 & 6.035 & 46.08 & 0.553 & 2.85 & 7.58 \\
\hline
\end{tabular}

* Calculated using the density and absolute viscosity of water

Each 1 litre solution was conditioned under a nitrogen atmosphere in order to ensure the removal of dissolved oxygen from solution. After 30 minutes, the magnetic stirrer was turned off and the RDE was lowered into solution. Solution samples were taken, using $10 \mathrm{ml}$ syringes, at time intervals of $15,30,60,90$, and 120 minutes. The potential on the surface of the copper disk was recorded with each sample taken. 


\section{Results and Discussion}

\subsection{Results of the Powder Cementation Experiments Testing Reproducibility}

The results of the experiments studying the reproducibility of experiments using the powder cementation reactor are presented in Figures 4.1, 4.2, and 4.3, which depict the relationships between $\mathrm{pH}$, solution potential, and gold concentration with time.

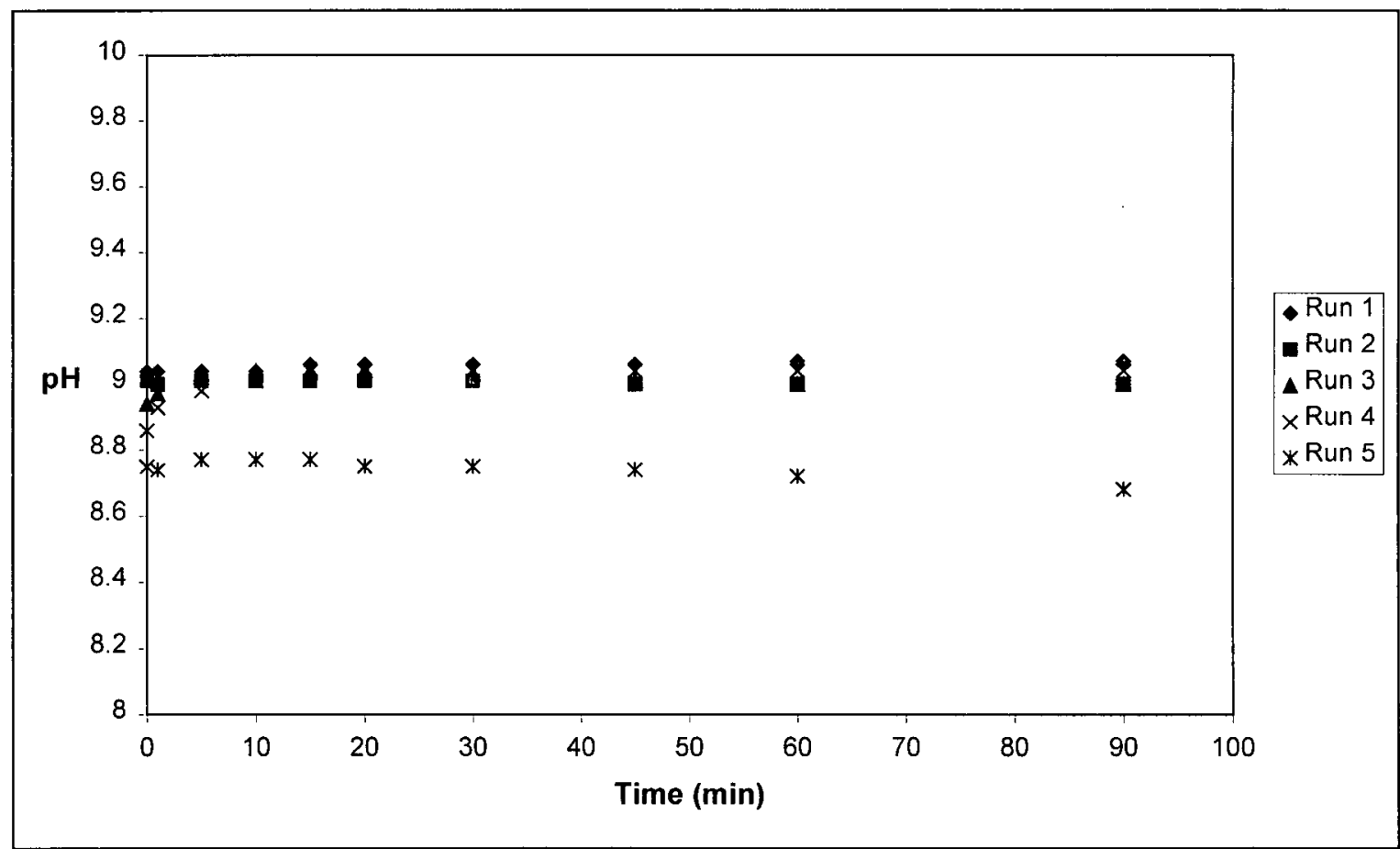

Figure 4.1: Behaviour of $\mathrm{pH}$. Initial Conditions: $13.33 \mathrm{ppm} \mathrm{Au}, 0.73 \mathrm{~mol} / 1 \mathrm{NH}_{3}, 0.1$ $\mathrm{mol} / \mathrm{l} \mathrm{S}_{2} \mathrm{O}_{3}{ }^{2-}, 0.1 \mathrm{~mol} / \mathrm{L} \mathrm{SO}_{3}{ }^{2-}, 1.0 \mathrm{~g} / \mathrm{l} \mathrm{Cu}^{2+}, 50^{\circ} \mathrm{C}, 3.75$ litre solution, $5.00 \mathrm{~g} \mathrm{Cu}$ powder

Under the standard experimental conditions of high $\mathrm{pH}$ and high temperature, significant ammonia losses, and an associated drop change in $\mathrm{pH}$, might be expected. However, as Figure 4.1 illustrates, the $\mathrm{pH}$ did not change significantly over time, in fact, rising slightly in certain runs. A relatively stable ammonia content was confirmed when the final ammonia concentration of one of the experimental runs was tested and determined to be $0.69 \mathrm{~mol} / \mathrm{l}$, only $0.04 \mathrm{~mol} / 1$ less than the original value of $0.73 \mathrm{~mol} / 1$. 


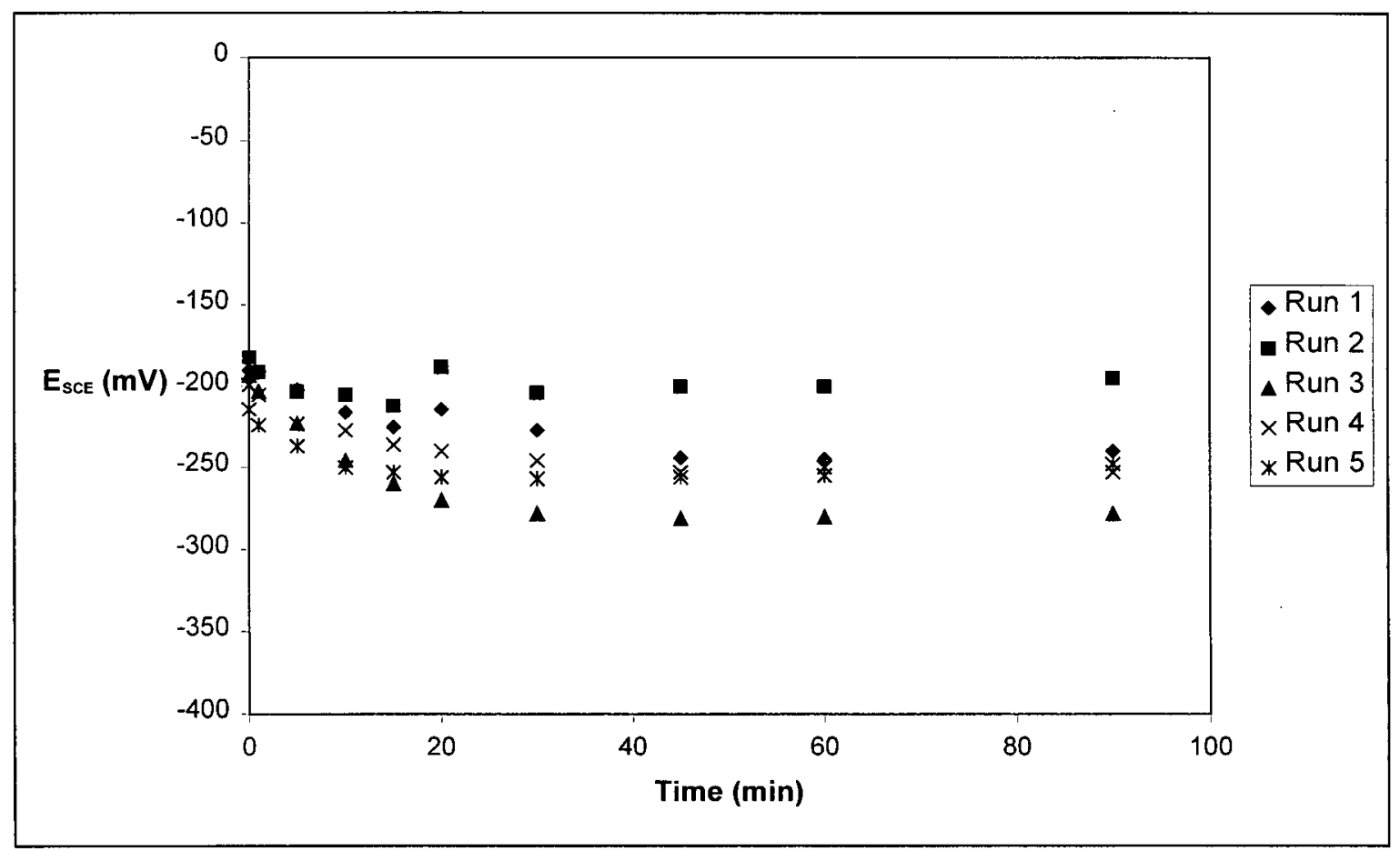

Figure 4.2: Behaviour of Solution Potential. Initial Conditions: $13.33 \mathrm{ppm} \mathrm{Au}, 0.73$ $\mathrm{mol} / / \mathrm{NH}_{3}, 0.1 \mathrm{~mol} / 1 \mathrm{~S}_{2} \mathrm{O}_{3}{ }^{2-}, 0.1 \mathrm{~mol} / 1 \mathrm{SO}_{3}{ }^{2-}, 1.0 \mathrm{~g} / 1 \mathrm{Cu}^{2+}, 50^{\circ} \mathrm{C}, 3.75$ litre solution, $5.00 \mathrm{~g}$ $\mathrm{Cu}$ powder

The lack of reproducibility in the solution potential curves, Figure 4.2, indicates that the measured solution potential is probably not sensitive to the progress of the gold cementation reaction, i.e. the solution potential is a mixed potential determined by the interaction of several reactions occurring concurrently. The general shape of the curves indicates that after its introduction, copper begins reducing species in solution, thereby, dropping the solution potential, quickly at first, gradually plateauing, and ending in a slight upturn in potential. The rise in potential is likely due to oxidation of $\mathrm{Cu}(\mathrm{I})$ to $\mathrm{Cu}(\mathrm{II})$ caused by entrainment of air into solution, occurring during sampling.

The most important feature of Figure 4.3 is that the cementation curves are all relatively closely matched. However, when quantifying the results by calculating the individual first order rate constants for each run, it becomes apparent there is a consistent negative deviation from simple first order kinetics. This point is illustrated in Figure 4.4 in which the averaged cementation data is modelled by the 'linear' model and by, what will be referred to as, the 'passivation' model, given by equation 4.1. 


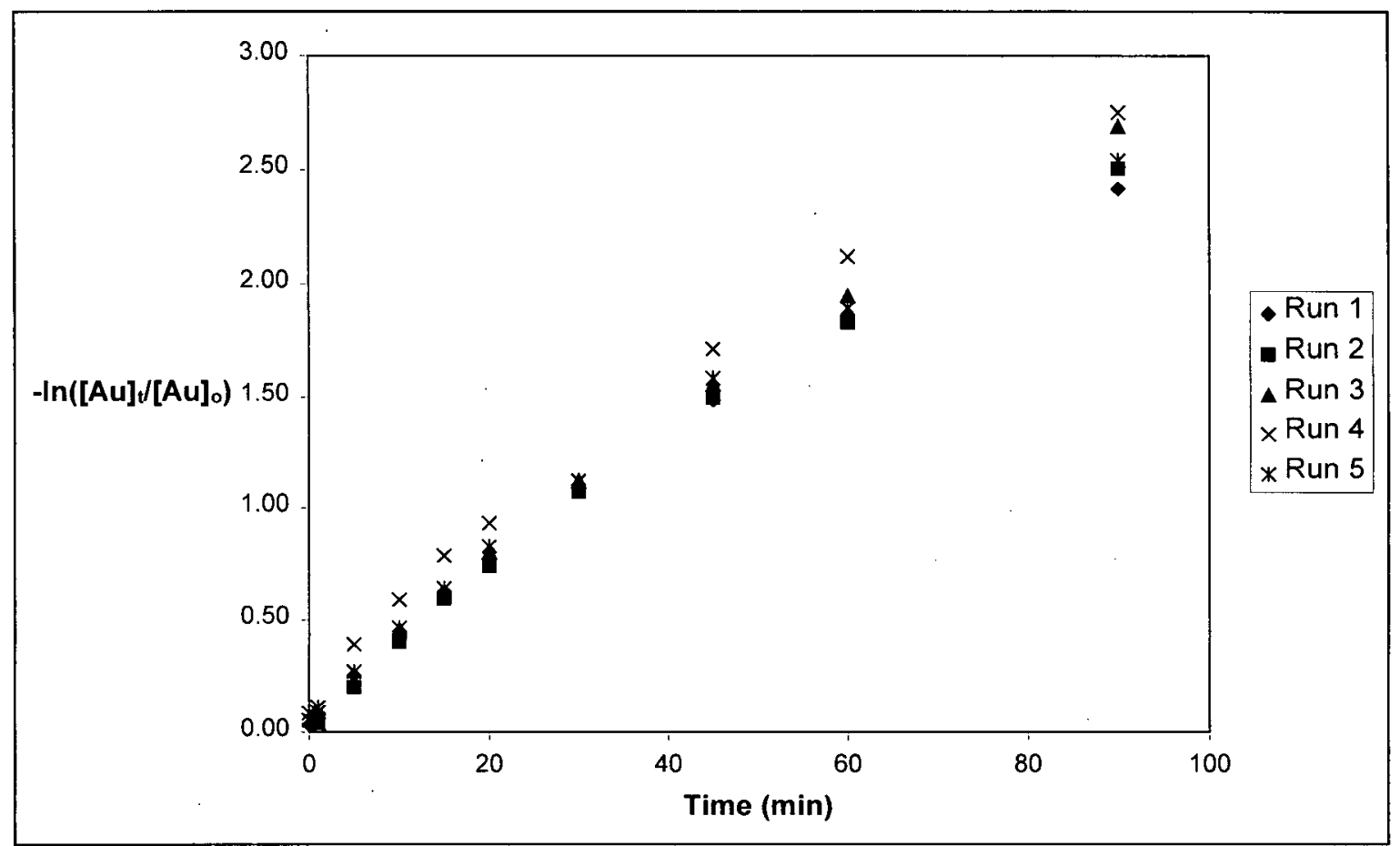

Figure 4.3: Gold Removal. Initial Conditions: $13.33 \mathrm{ppm} \mathrm{Au}, 0.73 \mathrm{~mol} / 1 \mathrm{NH}_{3}, 0.1 \mathrm{~mol} / \mathrm{l}$ $\mathrm{S}_{2} \mathrm{O}_{3}{ }^{2-}, 0.1 \mathrm{~mol} / 1 \mathrm{SO}_{3}{ }^{2-}, 1.0 \mathrm{~g} / \mathrm{l} \mathrm{Cu}^{2+}, 50^{\circ} \mathrm{C}, 3.75$ litre solution, $5.00 \mathrm{~g} \mathrm{Cu}$ powder

$\ln \left(\frac{C_{t}}{C_{0}}\right)=-k_{1}\left(\frac{A_{0}}{V}\right) t+\left(\frac{k_{1} k_{2}}{2 V}\right) t^{2}$

The first term in equation 4.1 contains the first order rate constant, $\mathrm{k}_{1}$, which can be either a chemical rate constant or diffusional rate constant depending on the mechanism of rate control. This term dominates the overall rate of cementation. The second term in the 'passivation' model, $\mathrm{k}_{1} \mathrm{k}_{2} / 2 \mathrm{~V}$, which also contains the first order rate constant, merely corrects for non-linear behaviour. It is claimed that the observed deviation from first order kinetics is due to the progressive formation of a passivating substance on the copper surface which decreases, with time, the area over which the cementation process takes place. The derivation of the 'passivation' model appears in Appendix D. 


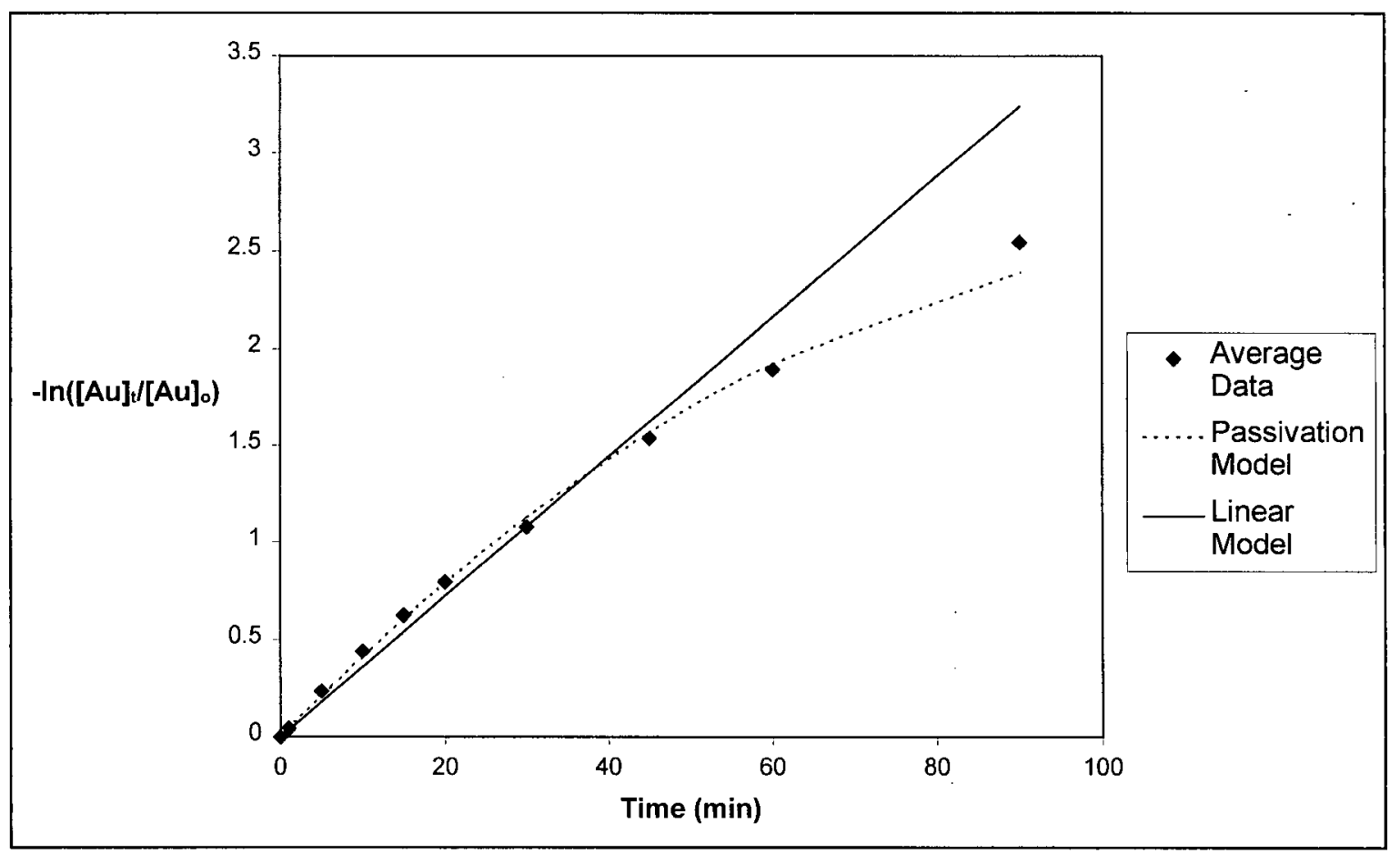

Figure 4.4: Comparison of Fit Between 'Passivation' Model and 'Linear' Model to Averaged Data. Initial Conditions: $13.33 \mathrm{ppm} \mathrm{Au}, 0.73 \mathrm{~mol} / 1 \mathrm{NH}_{3}, 0.1 \mathrm{~mol} / / \mathrm{S}_{2} \mathrm{O}_{3}{ }^{2-}, 0.1$ $\mathrm{mol} / 1 \mathrm{SO}_{3}{ }^{2-}, 1.0 \mathrm{~g} / 1 \mathrm{Cu}^{2+}, 50^{\circ} \mathrm{C}, 3.75$ litre solution, $5.00 \mathrm{~g} \mathrm{Cu}$ powder

\subsubsection{X-ray Diffraction Evidence of Formation of a Copper-Containing Deposit}

$\mathrm{X}$-ray diffraction analysis of the residues, after filtering and vacuum drying, indicated the presence of a significant quantity of cuprite, $\mathrm{Cu}_{2} \mathrm{O}$ (see Figure 4.5). The detection limit of the Siemens D5000 XRD analyser used for analysing the powder residues is 5 percent, suggesting that the level of cuprite in the sample was at least this value. An XRD analysis of the raw copper powder, which was washed with deionised water and dried as if it were a cementation residue, Figure 4.6, does not contain the cuprite peak. In order to test whether the formation of the copper-containing deposit was associated with the deposition of gold, an experimental run, without addition of gold to solution, was carried out under otherwise identical conditions. The copper powder was observed to progressively lose its lustre, becoming dull brown. An XRD analysis of the residues later confirmed the presence of cuprite. 


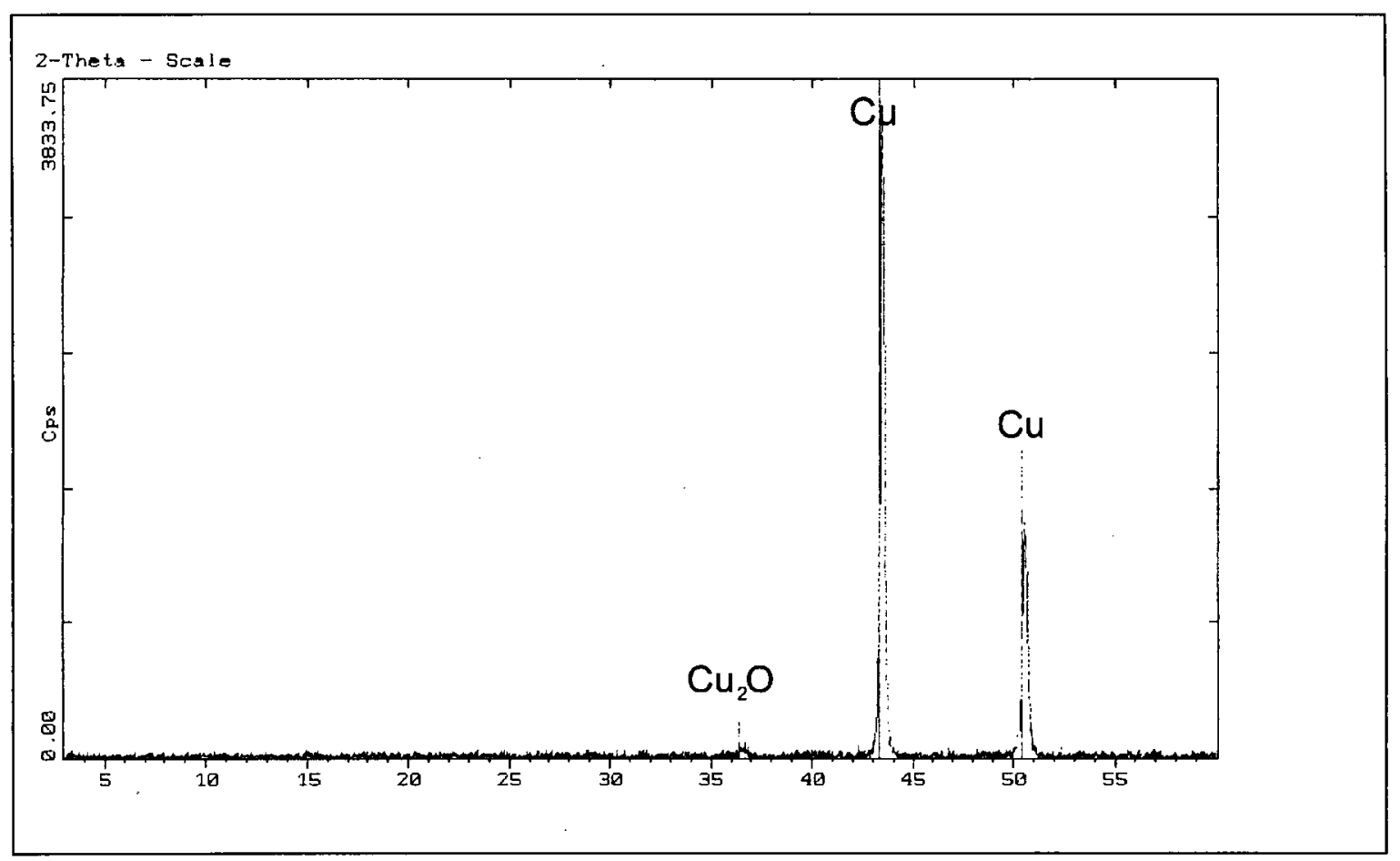

Figure 4.5: X-ray Diffraction Analysis of Copper Powder Residue of Reproducibility Experiment

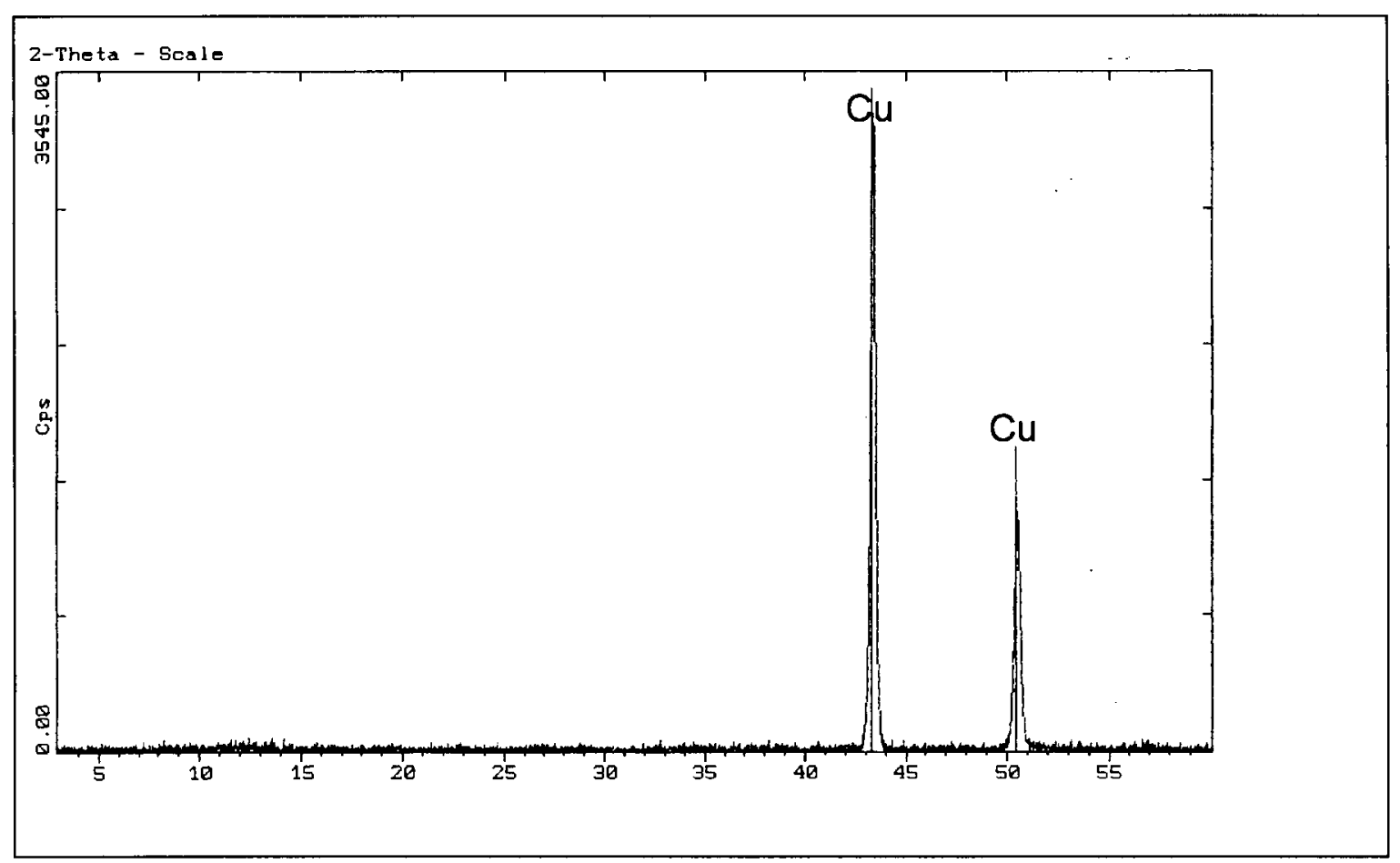

Figure 4.6: X-ray Diffraction Analysis of Raw Copper Powder After Filtering and Drying 


\subsubsection{Modelled Results}

SEM analysis of the raw copper powder, Figure 4.7, revealed that the powder was composed of nodular agglomerate-type particles. This made it impossible to estimate surface area based on average particle size. Consequently, the values for $k_{1}$ and $k_{2}$ in the 'passivation' model, equation 4.1, could not be solved for directly. The entire equation was instead simplified to the following form:

$\ln \left(\frac{\mathrm{C}_{\mathrm{t}}}{\mathrm{C}_{0}}\right)=-\mathrm{k}_{1}{ }^{\prime} \mathrm{t}+\mathrm{k}_{2}{ }^{\prime} \mathrm{t}^{2}$

The resulting values of $\mathrm{k}_{1}{ }^{\prime}$ and $\mathrm{k}_{2}{ }^{\prime}$ for each of the five runs are presented in Table 4.1.

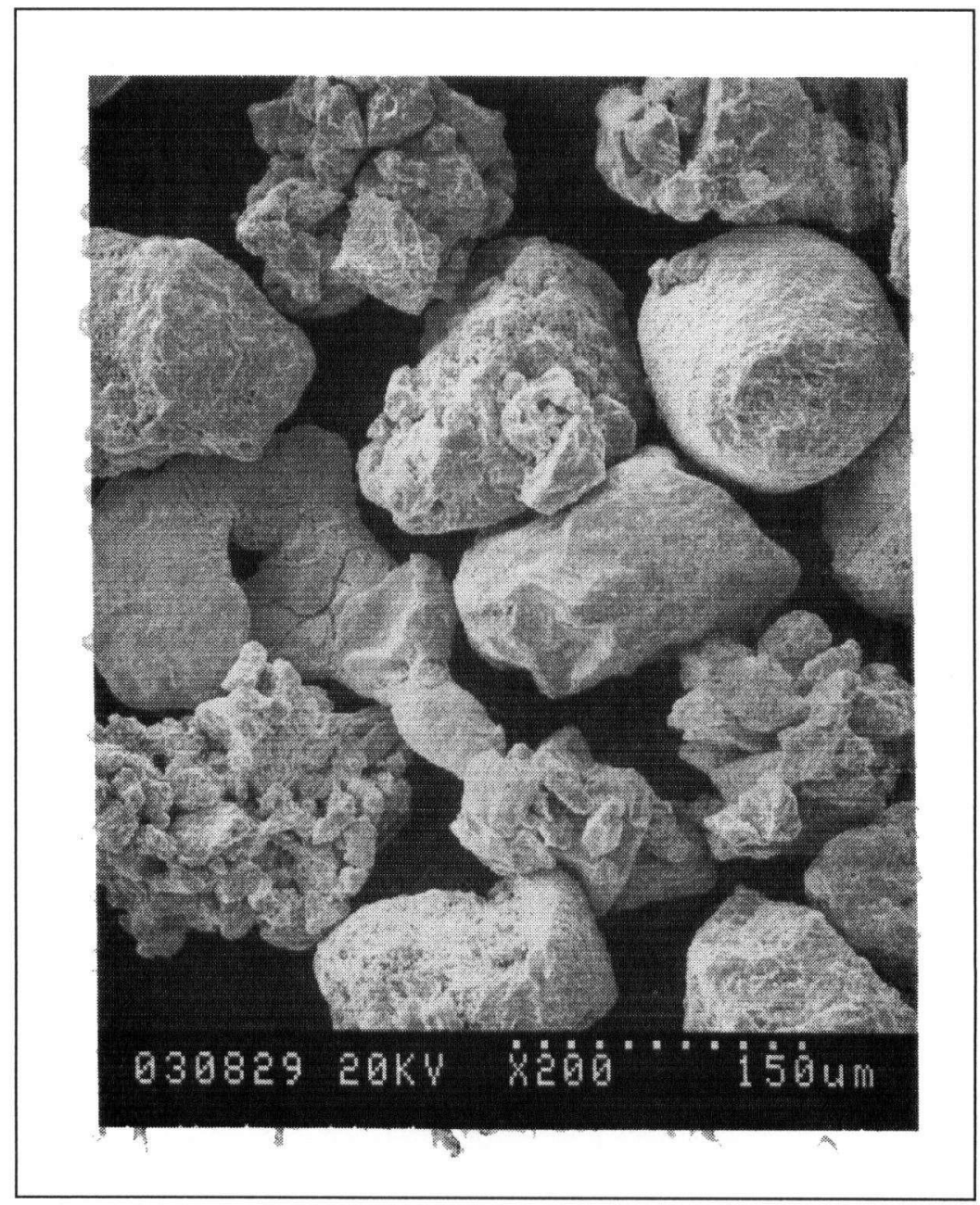

Figure 4.7: Copper Powder Before Cementation. Magnification 200X 
Table 4.1: Modelled Results of Experiments Testing Reproducibility. Initial Conditions: $13.33 \mathrm{ppm} \mathrm{Au}, 0.73 \mathrm{~mol} / / \mathrm{NH}_{3}, 0.1 \mathrm{~mol} / 1 \mathrm{~S}_{2} \mathrm{O}_{3}{ }^{2-}, 0.1 \mathrm{~mol} / 1 \mathrm{SO}_{3}{ }^{2-}, 1.0 \mathrm{~g} / \mathrm{C} \mathrm{Cu}^{2+}, 50^{\circ} \mathrm{C}, 3.75$ litre solution, $5.00 \mathrm{~g}$ Cu powder

\begin{tabular}{|c|c|c|c|c|c|c|c|c|}
\hline & Run \#1 & Run \#2 & Run \#3 & Run \#4 & Run \#5 & Mean & $\sigma$ & CV \\
\hline $\mathrm{k}_{1}{ }^{\prime}\left(\mathrm{s}^{-1} \times 10^{-4}\right)$ & 6.91 & 6.82 & 7.40 & 7.93 & 6.83 & 7.18 & 0.484 & 6.7 \\
\hline $\mathrm{k}_{2}{ }^{\prime}\left(\mathrm{s}^{-2} \times 10^{-8}\right)$ & 5.01 & 4.41 & 5.13 & 6.45 & 4.45 & 5.09 & 0.827 & 16.2 \\
\hline
\end{tabular}

These results indicate that measurements of $\mathrm{k}_{1}{ }^{\prime}$ are relatively precise, probably within 6.7 percent of their true values. In contrast, the values of $\mathrm{k}_{2}$ ' are relatively small and its measurement has a much greater degree of variance. Analysis of $k_{2}{ }^{\prime}$ is further complicated by the fact that its value is not independent of the value of $k_{1}$, i.e. both factors contain the first order rate constant $\mathrm{k}_{1}$. Thus, the factors affecting the value of $\mathrm{k}_{1}$ would be expected to similarly affect both $\mathrm{k}_{1}{ }^{\prime}$ and $\mathrm{k}_{2}{ }^{\prime}$.

\subsection{Results of the Powder Cementation Experiments to Determine the Rate Control Regime}

The calculated values for $\mathrm{k}_{1}{ }^{\prime}$ and $\mathrm{k}_{2}{ }^{\prime}$ are presented in Table 4.2 along with the corresponding temperature at which the experimental run was performed.

Table 4.2: Modelled Results of Experiments to Determine the Rate Control Regime. Initial Conditions: $13.33 \mathrm{ppm} \mathrm{Au}, 0.73 \mathrm{~mol} / 1 \mathrm{NH}_{3}, 0.1 \mathrm{~mol} / 1 \mathrm{~S}_{2} \mathrm{O}_{3}{ }^{2-}, 0.1 \mathrm{~mol} / 1 \mathrm{SO}_{3}{ }^{2-}, 1.0$ $\mathrm{g} / \mathrm{l} \mathrm{Cu}{ }^{2+}, 3.75$ litre solution, $5.00 \mathrm{~g} \mathrm{Cu}$ powder

\begin{tabular}{|l|c|c|c|c|c|}
\hline Temperature $\left({ }^{\circ} \mathrm{C}\right)$ & 60 & 50 & 40 & 31 & 18 \\
\hline $\mathrm{k}_{1}{ }^{\prime}\left(\mathrm{s}^{-1} \times 10^{-4}\right)$ & 7.47 & 7.16 & 5.06 & 4.58 & 3.07 \\
\hline $\mathrm{k}_{2}{ }^{\prime}\left(\mathrm{s}^{-2} \times 10^{-8}\right)$ & 4.85 & 5.07 & 2.14 & 1.78 & 0.90 \\
\hline
\end{tabular}

Since the only element variant in $\mathrm{k}_{1}{ }^{\prime}$ was the first order rate constant, $\mathrm{k}_{1}$, its dependence on temperature should be described by the Arrhenius equation. The activation energy was calculated from the slope of an Arrhenius plot, Figure 4.9, to be $17.6 \pm 6.2 \mathrm{~kJ} / \mathrm{mol}$ ( $95 \%$ confidence), which places the process in the regime of diffusion control. The highly dispersed bulbous appearance of the gold deposits, as revealed by an SEM photomicrograph of the surface of a copper residue particle, Figure 4.8, also supports the assertion that the cementation process is under diffusion control. 


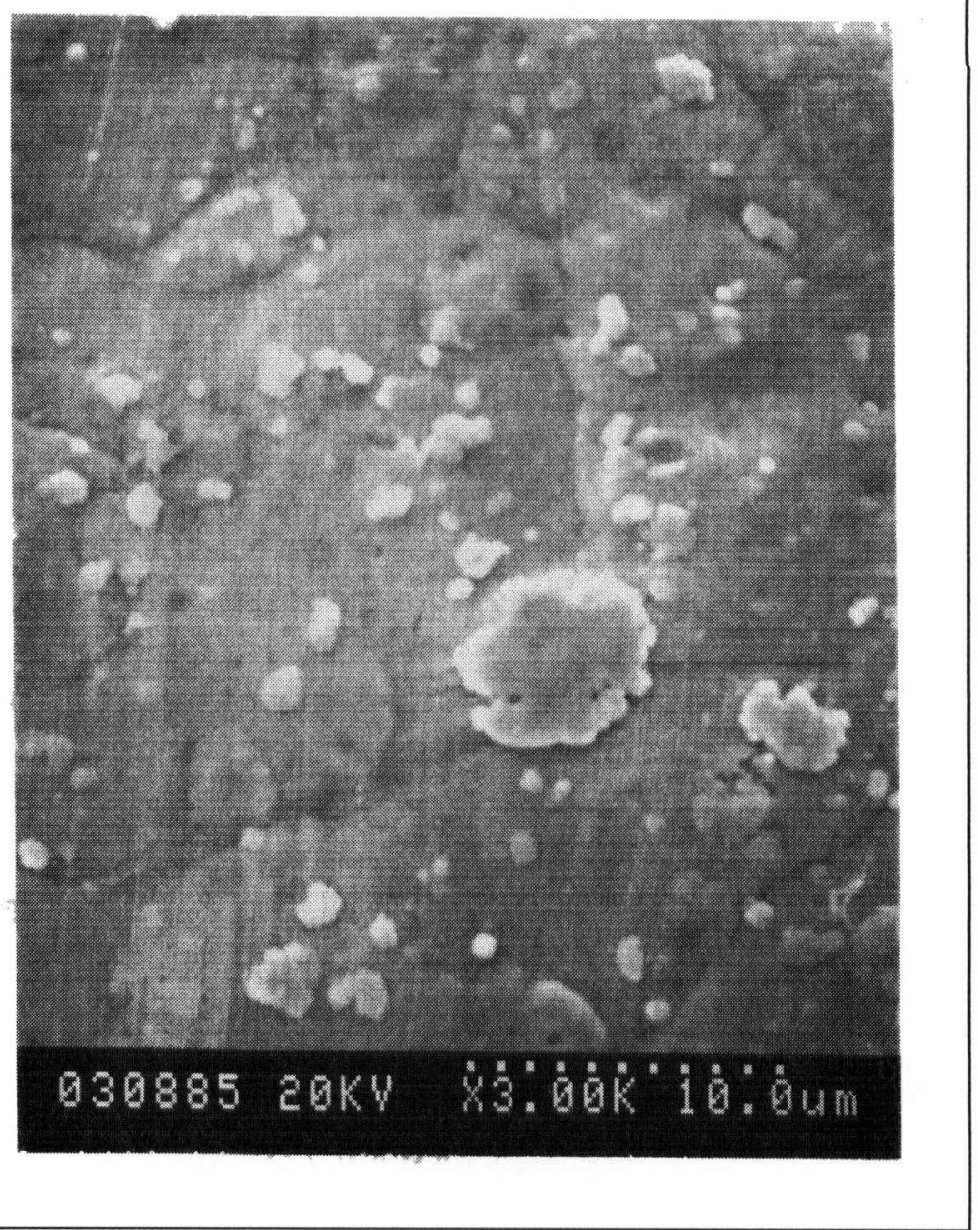

Figure 4.8: Morphology of Gold Deposits on Copper Powder Residue. Magnification $3000 X$. Initial Conditions: $13.33 \mathrm{ppm} \mathrm{Au}, 0.73 \mathrm{~mol} / 1 \mathrm{NH}_{3}, 0.1 \mathrm{~mol} / \mathrm{l} \mathrm{S}_{2} \mathrm{O}_{3}{ }^{2-}, 0.1 \mathrm{~mol} / 1$ $\mathrm{SO}_{3}{ }^{2-}, 1.0 \mathrm{~g} / \mathrm{Cu}^{2+}, 3.75$ litre solution, $5.00 \mathrm{~g} \mathrm{Cu}$ powder 


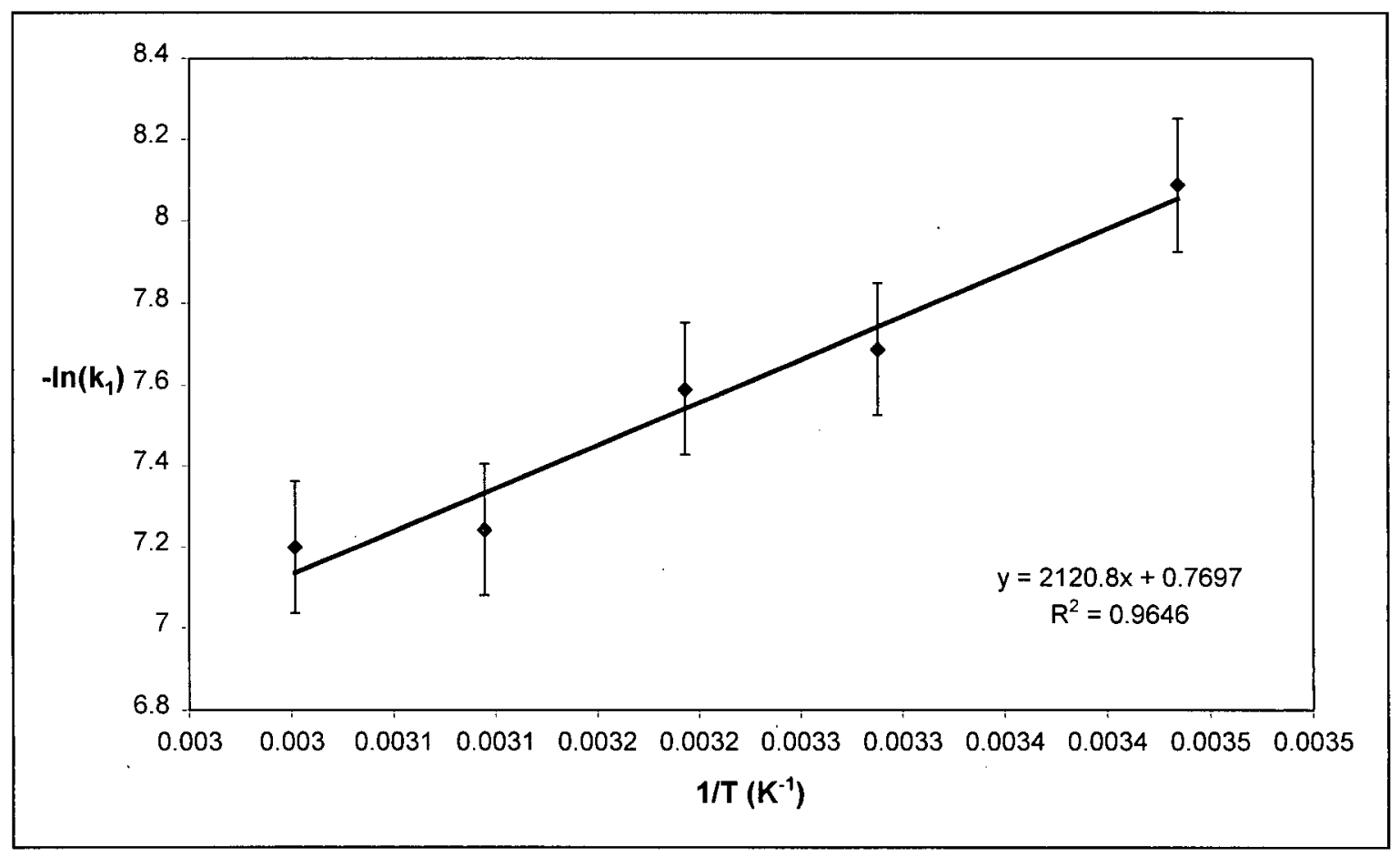

Figure 4.9: Arrhenius Plot for Gold Cementation. Initial Conditions: $13.33 \mathrm{ppm} \mathrm{Au}, 0.73$ $\mathrm{mol} / / \mathrm{NH}_{3}, 0.1 \mathrm{~mol} / 1 \mathrm{~S}_{2} \mathrm{O}_{3}{ }^{2-}, 0.1 \mathrm{~mol} / / \mathrm{SO}_{3}{ }^{2-}, 1.0 \mathrm{~g} / \mathrm{l} \mathrm{Cu}^{2+}, 3.75$ litre solution, $5.00 \mathrm{~g} \mathrm{Cu}$ powder

\subsection{Results of the Fractional Factorial Design Experiment}

The calculated values of $\mathrm{k}_{1}{ }^{\prime}$ and $\mathrm{k}_{2}{ }^{\prime}$ corresponding to the sixteen different experimental conditions described in Section 3.1.2 are presented in Table 4.3. No correlation could be established between changes in solution potential and the magnitudes of calculated rate constants, indicating that the progress of the gold cementation reaction does not significantly affect solution potential. The oxidation/reduction behaviour of other species in solution must, therefore, dominate the measured solution potential.

Table 4.3: Modelled Results of Factorial Design Experiment

\begin{tabular}{|c|c|c|c|c|c|c|c|c|}
\hline Standard \# & 1 & 2 & 3 & 4 & 5 & 6 & 7 & 8 \\
\hline $\mathrm{k}_{1}{ }^{\prime}\left(\mathrm{s}^{-1} \times 10^{-4}\right)$ & 16.13 & 3.98 & 9.79 & 10.79 & 3.47 & 2.80 & 11.75 & 4.39 \\
\hline $\mathrm{k}_{2}{ }^{-2}\left(\mathrm{~s}^{-2} \times 10^{-8}\right)$ & 19.6 & 3.31 & 1.72 & 8.30 & 2.75 & 2.67 & 9.95 & 4.08 \\
\hline Standard \# & 9 & 10 & 11 & 12 & 13 & 14 & 15 & 16 \\
\hline $\mathrm{k}_{1}{ }^{\prime}\left(\mathrm{s}^{-1} \times 10^{-4}\right)$ & 19.41 & 26.32 & 26.38 & 17.27 & 15.70 & 5.86 & 13.55 & 16.93 \\
\hline $\mathrm{k}_{2}{ }^{\prime}\left(\mathrm{s}^{-2} \times 10^{-8}\right)$ & 9.42 & 40.0 & 29.9 & 1.20 & 18.0 & 7.06 & 10.7 & 17.3 \\
\hline
\end{tabular}




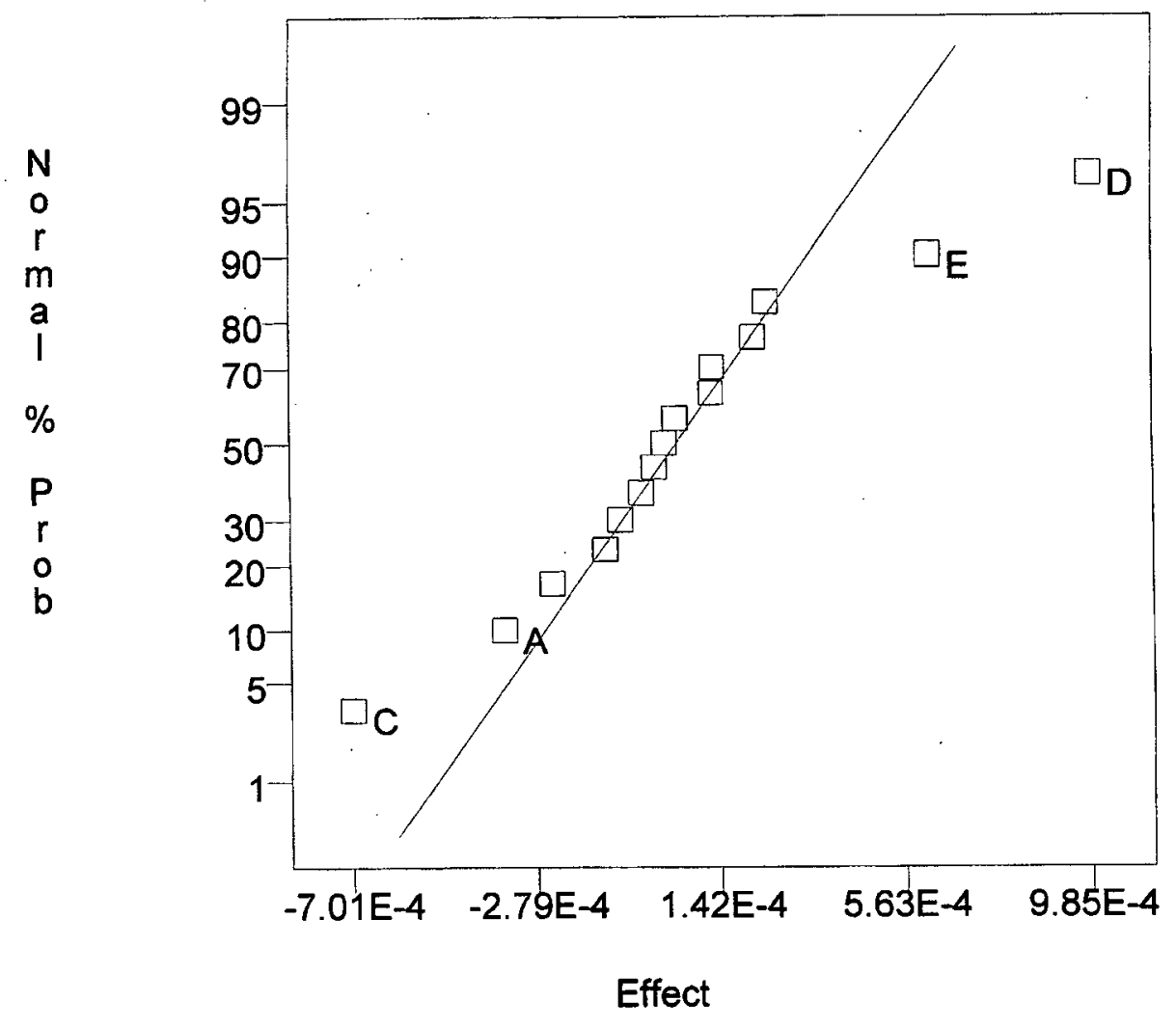

Figure 4.10: Normal Probability Plot for $\mathrm{k}_{1}{ }^{\prime}$

By inspection of the normal probability plot for $\mathrm{k}_{\mathrm{l}}{ }^{\prime}$, Figure 4.10 , it is apparent that factors $\mathrm{C}, \mathrm{D}$, and $\mathrm{E}$ (coded for sulphite concentration, $\mathrm{pH} / \mathrm{ammonia}$ concentration, and temperature, respectively), by virtue of their large deviations from the normal distribution model represented by the straight line, all significantly affect the value of $k_{1}{ }^{\prime}$. When applying the standard 95 percent confidence criteria, however, factor A (copper concentration) must also be included as having a significant effect on $\mathrm{k}_{1}$ ' (see values of $|\mathrm{t}|$ in Appendix E). All other main and second order interaction effects are described by the normal distribution model and are, thus, deemed to have insignificant effects on the value of $\mathrm{k}_{1}{ }^{\prime}$. Note that this statement is only true for the prescribed values of these variables and should not be extrapolated beyond their tested ranges. The degree of importance of each factor is given by the relative magnitude of their respective coefficients in the final equation of coded factors, equation 4.3. 
$\mathrm{k}_{1}{ }^{\prime}=0.00128-0.00018 \times \mathrm{A}-0.00035 \times \mathrm{C}+0.00049 \times \mathrm{D}+0.00031 \times \mathrm{E}$

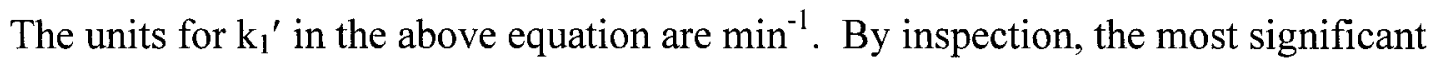
effect is that of $\mathrm{pH} /$ ammonia concentration (D), followed by sulphite concentration (C), temperature (E), and finally copper concentration (A). The resulting equation that defines $k_{1}{ }^{\prime}$ in terms of these four uncoded variables appears as equation 4.4.

$\mathrm{k}{ }^{\prime}=-0.00032-0.00354 \times[\mathrm{Cu}]-0.00701 \times\left[\mathrm{SO}_{3}{ }^{2-}\right]+0.00197 \times\left(\mathrm{NH}_{3}\right)+0.00003 \times \mathrm{T}$

In the above equation, temperature is inputted in degrees Celsius while sulphite and ammonia concentrations are in mol/l and copper concentration is in $\mathrm{g} / \mathrm{l}$. This equation is able to account for 90 percent of the variance in $\mathrm{k}_{1}{ }^{\prime}$.

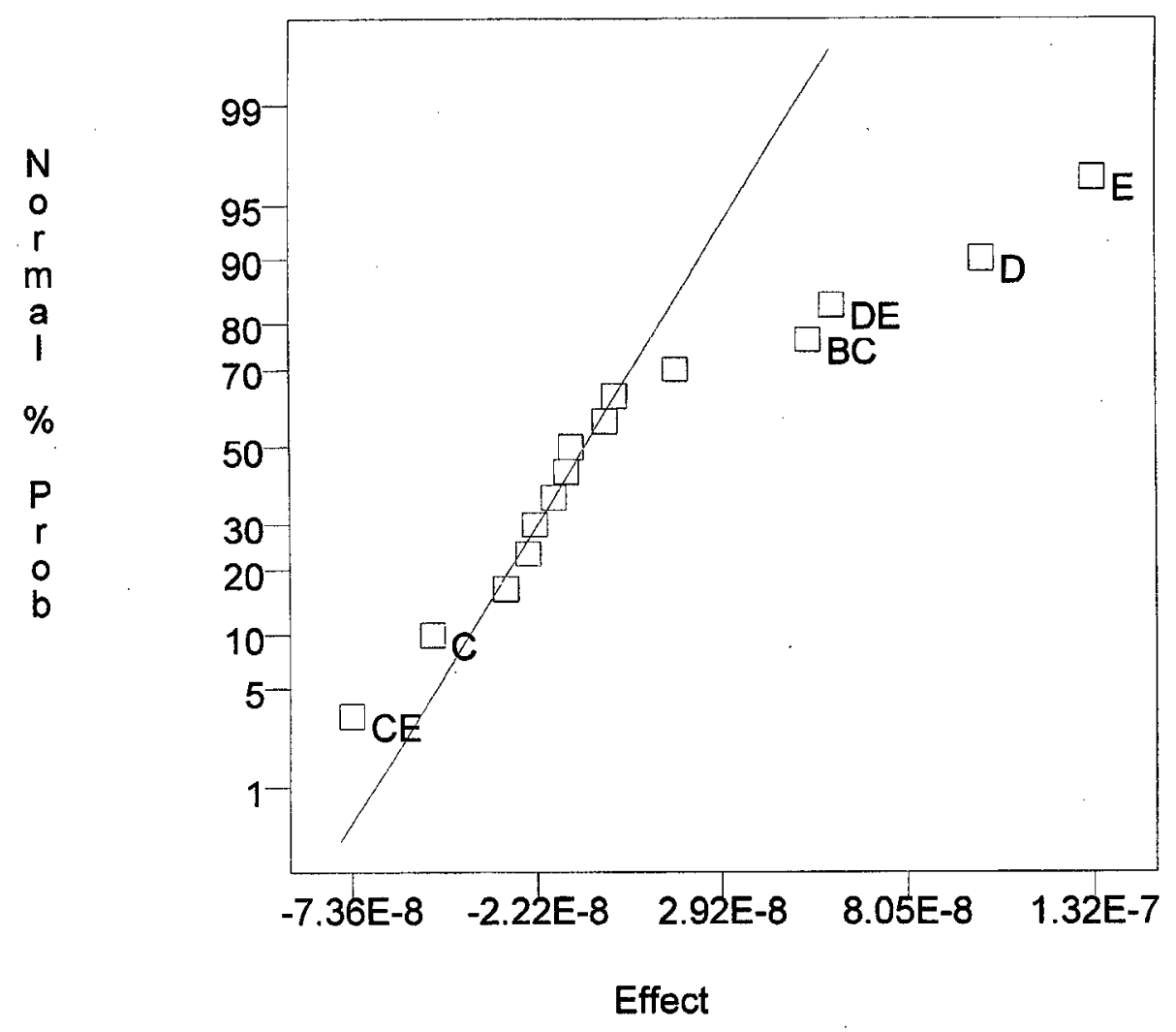

Figure 4.11: Normal Distribution Plot for $\mathrm{k}_{2}{ }^{\prime}$ 


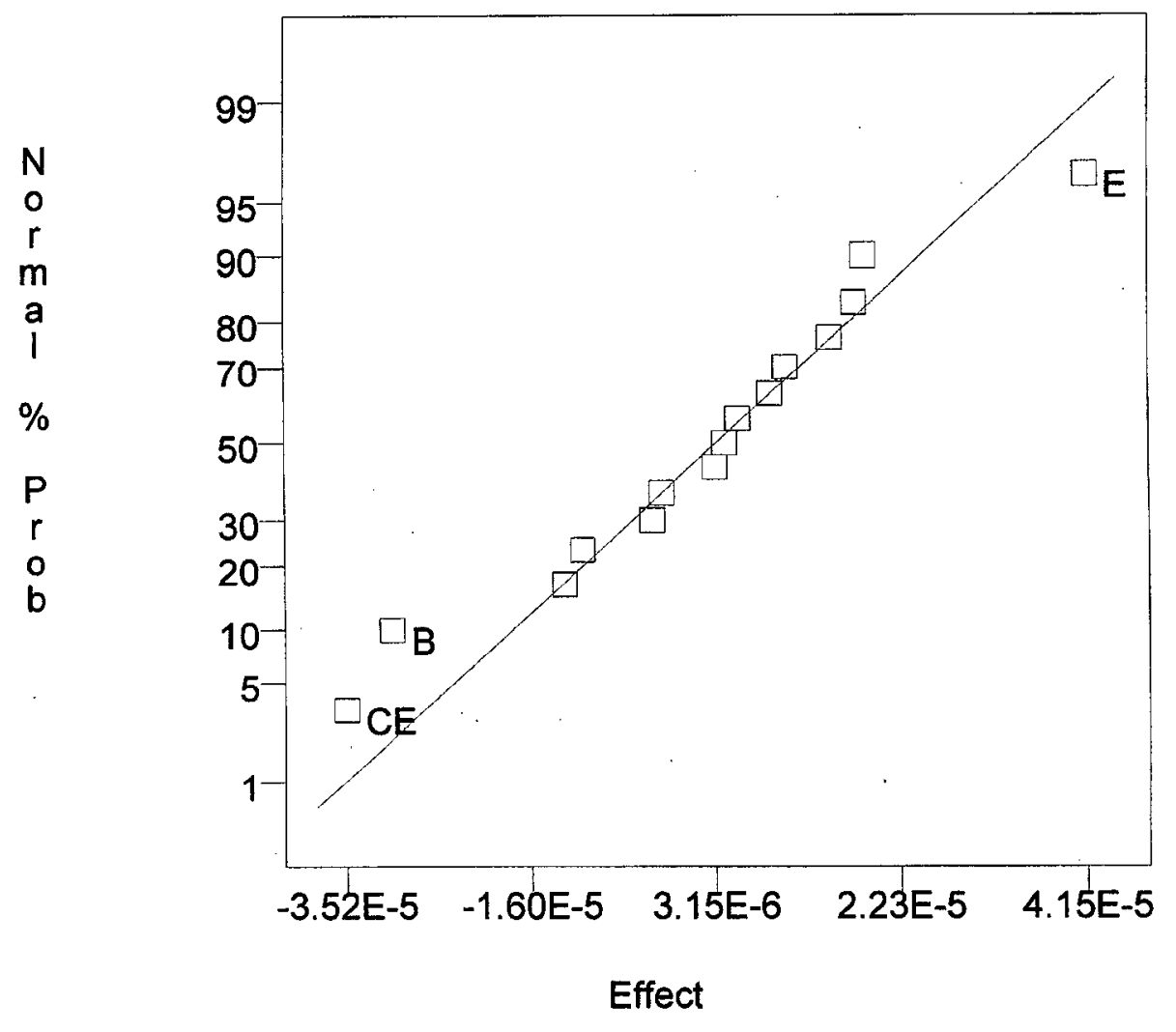

Figure 4.12: Normal Probability Plot for $\mathrm{k}_{2}{ }^{\prime} / \mathrm{k}_{1}{ }^{\prime}$

Analysis of $\mathrm{k}_{2}{ }^{\prime}$ is much more complicated than that of $\mathrm{k}_{1}{ }^{\prime}$. A unique feature of the normal distribution plot for $\mathrm{k}_{2}{ }^{\prime}$, Figure 4.11, is the appearance of interaction effects, e.g. DE ( $\mathrm{pH} /$ ammonia concentration and temperature), $\mathrm{CE}$ (sulphite concentration and temperature), and $\mathrm{BC}$ (thiosulphate concentration and sulphite concentration). Analysis is further complicated since the model is not hierarchical, i.e. interaction effect $\mathrm{BC}$ does follow from the inclusion of both main effects $\mathrm{B}$ and $\mathrm{C}$. Interaction effect $\mathrm{BC}$ could, therefore, equally represent the interaction effect ADE. As predicted, some of the factors affecting the value of $\mathrm{k}_{1}{ }^{\prime}$ have a similar effect on $\mathrm{k}_{2}{ }^{\prime}$, e.g. temperature (E), $\mathrm{pH} / \mathrm{ammonia}$ concentration (D), and sulphite concentration (C). When a normal probability plot is constructed for $\mathrm{k}_{2}{ }^{\prime} / \mathrm{k}_{1}$, Figure 4.12 , in order to eliminate the confounding effect of $\mathrm{k}_{1}$, the common effects of sulphite concentration (C) and $\mathrm{pH} /$ ammonia concentration (D) are eliminated. The resulting model, however, is again non-hierarchical and even more variant than the previous model due to the incorporation of the variance in $\mathrm{k}_{1}{ }^{\prime}$. Overall, 
the confounding of effects, the non-hierarchical nature of the models, and the relatively large variance in measurement of $\mathrm{k}_{2}{ }^{\prime}$ make further analysis of $\mathrm{k}_{2}{ }^{\prime}$ extremely difficult and beyond the scope of this work.

The rate of removal of gold from solution is dominated by the value of $\mathrm{k}_{1}{ }^{\prime}$, which contains the diffusion coefficient of the gold species being deposited. Thus, the factors affecting the value of $k_{1}$ ' are of much greater interest in terms how they affect overall cementation performance. Some of the possible reasons for the importance of each factor affecting the value of $\mathrm{k}_{1}{ }^{\prime}$ are discussed in the following sections.

\subsubsection{Effect of Initial Sulphite Concentration}

SEM analyses using an X-ray energy dispersive spectrometer consistently revealed that the cementates on the copper powder residues were primarily made up of sulphur and copper. Some sulphur could be detected in gold deposits though the sulphur content varied considerably. Sulphite's negative effect on the value of $k_{1}{ }^{\prime}$ in combination with SEM evidence suggests that it is reduced on the surface of metallic copper. By assuming the products of reduction to be cuprite, $\mathrm{Cu}_{2} \mathrm{O}$, and chalcocite, $\mathrm{Cu}_{2} \mathrm{~S}$, it can be demonstrated that reduction of both sulphite and thiosulphate by metallic copper, under standard solution conditions, are thermodynamically favourable (see Appendix F). The reduction of sulphite would decrease the effective area over which cementation takes place, $A_{0}$, since the total area would have to be proportioned between the cementation reaction and the sulphite reduction reaction. An SEM photomicrograph, Figure 4.13, exposes the somewhat spiked appearance of the sulphur precipitates and deposits with high sulphur content. 


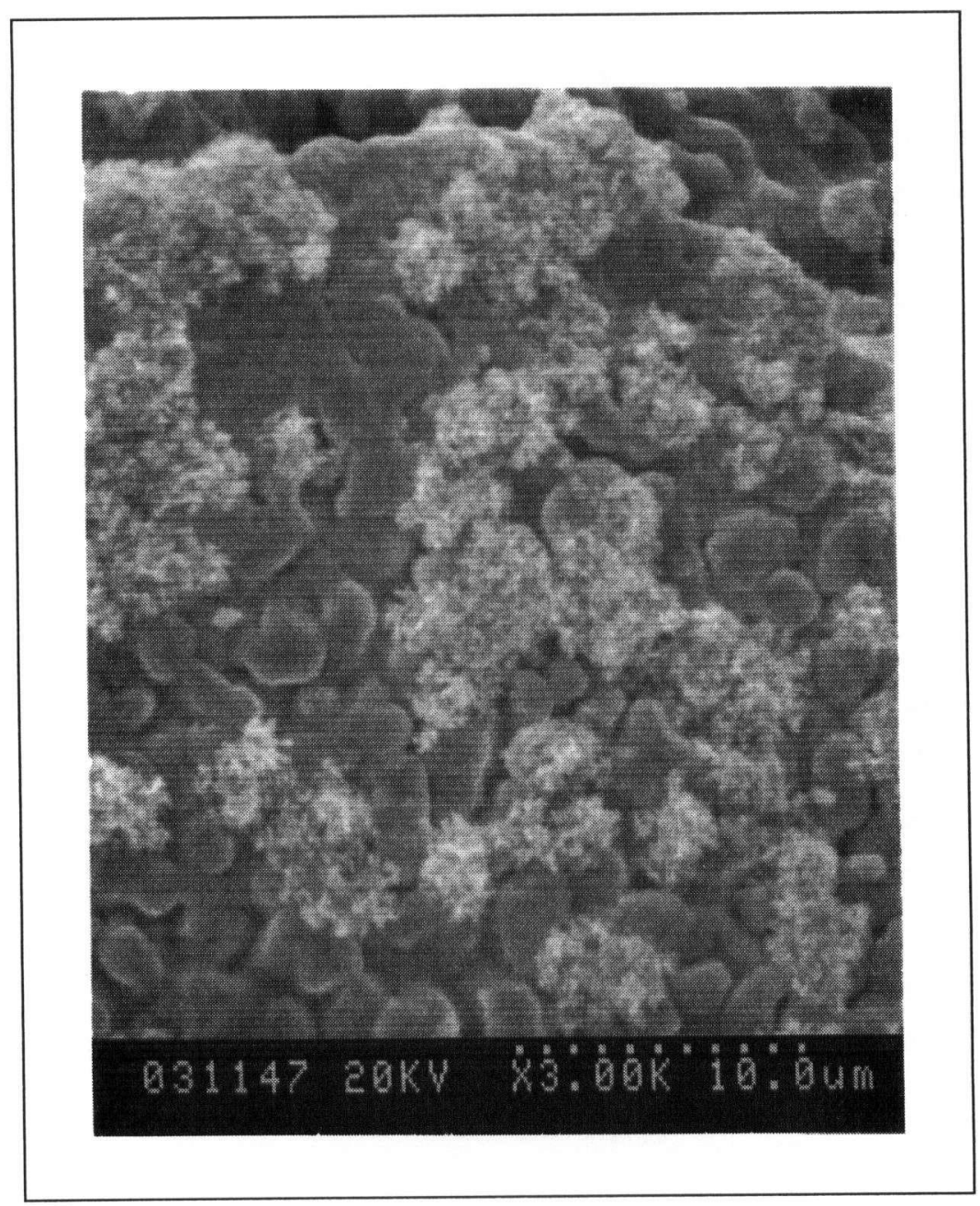

Figure 4.13: Morphology of Sulphur Deposits on Copper Powder Residue. Magnification 3000X

It is proposed that reduction of sulphite by copper forms a precipitate on the surface of copper powder particles, which later decompose when dried to cuprite, $\mathrm{Cu}_{2} \mathrm{O}$, and some other sulphur bearing species. Measurements of changes in sulphite concentration in order to confirm this hypothesis were not performed. However, it can be demonstrated that an extremely small change in sulphite concentration can account for all cuprite formation observed by X-ray diffraction analysis (see Appendix G). Thus, even if measurements of changes in sulphite concentration were conducted and found to be undetectable, it would still not exclude the possibility that the precipitates formed on the copper powder residues are the result of sulphite reduction. This is similarly true for thiosulphate. Analyses of changes in thiosulphate concentration under similar solution conditions to those of the factorial design experiment did not reveal significant changes 
in concentration (see Appendix H). However, it is still probable that thiosulphate is reduced by metallic copper during cementation. Even when sulphite was not a constituent of a test solution, widespread sulphur deposition was consistently detected in the cementation residues. The observed lack of significance of thiosulphate concentration on cementation kinetics may be due to the relatively narrow concentration range of thiosulphate tested, i.e. the difference between $0.036 \mathrm{~mol} / \mathrm{l}$ and $0.100 \mathrm{~mol} / \mathrm{l}$ may not be large enough to have a detectable effect on cementation kinetics.

\subsubsection{Effect of Initial $\mathrm{pH} / \mathrm{ammonia}$ Concentration}

A possible reason for the positive effect of high $\mathrm{pH} /$ ammonia concentration is that at high ammonia concentrations a significant amount of gold may exist as diamminegold(I), $\mathrm{Au}\left(\mathrm{NH}_{3}\right)_{2}{ }^{+}$, rather than bis(thiosulphato)aurate(I), $\mathrm{Au}\left(\mathrm{S}_{2} \mathrm{O}_{3}\right)_{2}{ }^{3-}$.

$\mathrm{Au}\left(\mathrm{NH}_{3}\right)_{2}{ }^{+}+2 \mathrm{~S}_{2} \mathrm{O}_{3}{ }^{2-} \rightarrow \mathrm{Au}\left(\mathrm{S}_{2} \mathrm{O}_{3}\right)_{2}{ }^{3-}+2 \mathrm{NH}_{3}$

The smaller gold-ammine complex should be much more mobile than the bulkier goldthiosulphate complex, leading to faster cementation. Using the Nernst equation, the equilibrium ratio of the concentrations of these two gold complexes can be calculated as a function of free ammonia concentration, thiosulphate concentration, and temperature.

$\Delta \mathrm{G}^{\mathrm{o}}=-22.6 \mathrm{~kJ} / \mathrm{mol}=-\mathrm{R} \operatorname{Tln}\left(\frac{\left(\mathrm{NH}_{3}\right)^{2} \times\left[\mathrm{Au}\left(\mathrm{S}_{2} \mathrm{O}_{3}\right)_{2}{ }^{3-}\right]}{\left[\mathrm{S}_{2} \mathrm{O}_{3}{ }^{2-}\right]^{2} \times\left[\mathrm{Au}\left(\mathrm{NH}_{3}\right)_{2}{ }^{+}\right]}\right)$

As illustrated in Table 4.4, ammonia concentration has the most significant affect on the equilibrium concentrations of these two species.

In literature, high $\mathrm{pH} / \mathrm{ammonia}$ concentration was cited as the cause of poor cementation performance due to decreased current efficiency caused by oxidation of metallic copper and concomitant copper-ammine complex formation ${ }^{[1]}$. The decreased current efficiency was mainly due to exposure of the test solution to air which caused oxygen to dissolve into solution. Dissolved oxygen can both directly attack the surface of copper particles or indirectly, by oxidising cuprous ions to cupric ions which may subsequently be reduced on the surface of copper particles. In this study, entry of dissolved oxygen into the 
reactor was minimised, and hence, the entry of copper ions into solution via this mechanism was not as important. Copper ions primarily entered solution vịa the gold cementation reaction and, possibly, by reduction of sulphite and/or thiosulphate. In this case, formation of copper-ammine complexes would assist in preserving the surface area available for cementation by stabilising copper ions entering solution, thereby, avoiding copper precipitation.

Table 4.4: Equilibrium Gold Speciation

\begin{tabular}{|c|c|c|c|c|c|}
\hline $\begin{array}{c}\text { Temp. } \\
\left({ }^{\circ} \mathrm{C}\right)\end{array}$ & $\mathrm{pH}$ & $\begin{array}{c}\left(\mathrm{NH}_{3}\right)_{\text {total }} \\
(\mathrm{mol} / \mathrm{l})\end{array}$ & $\begin{array}{c}\left(\mathrm{NH}_{3}\right)_{\text {free }}{ }^{*} \\
(\mathrm{~mol} / \mathrm{l})\end{array}$ & $\begin{array}{c}{\left[\mathrm{S}_{2} \mathrm{O}_{3}{ }^{2-}\right]^{* *}} \\
(\mathrm{~mol} / /)\end{array}$ & $\begin{array}{c}\% \mathrm{Au} \text { as } \\
{\left[\mathrm{Au}\left(\mathrm{NH}_{3}\right)_{2}{ }^{+}\right]}\end{array}$ \\
\hline 50 & 9.43 & 0.73 & 0.647 & 0.036 & 6.7 \\
\hline 50 & 9.28 & 0.73 & 0.618 & 0.100 & 0.8 \\
\hline 30 & 9.94 & 0.73 & 0.638 & 0.036 & 3.8 \\
\hline 30 & 9.73 & 0.73 & 0.591 & 0.100 & 0.4 \\
\hline 50 & 7.44 & 0.20 & 0.015 & 0.036 & 0.0 \\
\hline 50 & 7.41 & 0.20 & 0.014 & 0.100 & 0.0 \\
\hline 30 & 7.46 & 0.20 & 0.004 & 0.036 & 0.0 \\
\hline 30 & 7.50 & 0.20 & 0.005 & 0.100 & 0.0 \\
\hline
\end{tabular}

* Calculated from the $\mathrm{NH}_{4}{ }^{+} / \mathrm{NH}_{3}$ equilibrium reaction, $\Delta G^{\circ}=-52.8 \mathrm{~kJ} / \mathrm{mol}$, using the observed $p H$, temperature, and total ammonia concentration

** Actual free thiosulphate concentrations may be lower due to formation of the cuprousthiosulphate complex, $\mathrm{Cu}\left(\mathrm{S}_{2} \mathrm{O}_{3}\right)_{3}{ }^{5-}$

\subsubsection{Effect of Temperature}

Evidence that the cementation of gold onto copper is under diffusion control was presented in Section 4.2. The improvement in cementation performance caused by increasing temperature can, therefore, be explained by the associated drop in solvent viscosity, which allows the gold complexes to move more freely through solution.

\subsubsection{Effect of Initial Copper Concentration}

The negative effect of initial copper concentration probably stems from the fact that copper was introduced into solution as copper sulphate, i.e. $\mathrm{Cu}$ (II). Cupric ions in ammoniacal solution predominantly exist as cupric tetrammine, $\mathrm{Cu}\left(\mathrm{NH}_{3}\right)_{4}{ }^{2+}$. Formation 
of this complex could have a negative effect on the rate of cementation by decreasing the concentration of the gold-ammine complex, $\mathrm{Au}\left(\mathrm{NH}_{3}\right)_{2}{ }^{+}$, due to 'tie-up' of ammonia.

During cementation experiments, the blue colour of cupric tetrammine was consistently observed to gradually fade after introduction of copper powder. Cupric tetrammine may react with metallic copper to form a cuprous-thiosulphate complex, $\mathrm{Cu}\left(\mathrm{S}_{2} \mathrm{O}_{3}\right)_{3}{ }^{5-}$.

$\mathrm{Cu}\left(\mathrm{NH}_{3}\right)_{4}{ }^{2+}+6 \mathrm{~S}_{2} \mathrm{O}_{3}{ }^{2-}+\mathrm{Cu} \rightarrow 2 \mathrm{Cu}\left(\mathrm{S}_{2} \mathrm{O}_{3}\right)_{3}{ }^{5-}+4 \mathrm{NH}_{3}$

$\Delta \mathrm{G}^{\mathrm{o}}=-128.66 \mathrm{~kJ} / \mathrm{mol}=-\mathrm{RT} \ln \left(\frac{\left(\mathrm{NH}_{3}\right)^{4} \times\left[\mathrm{Cu}\left(\mathrm{S}_{2} \mathrm{O}_{3}\right)_{3}{ }^{5-}\right]^{2}}{\left[\mathrm{~S}_{2} \mathrm{O}_{3}{ }^{2-}\right]^{6} \times\left[\mathrm{Cu}\left(\mathrm{NH}_{3}\right)_{4}{ }^{2+}\right]}\right)$

The relatively large equilibrium ratios of the cuprous-thiosulphate complex to cupric tetrammine, presented in Table 4.5, indicate that this reaction is highly favoured to product side under all solution conditions tested.

Table 4.5: Equilibrium Ratio of Cupric Tetrammine to Cuprous-Thiosulphate Complex Under Standard Solution Conditions

\begin{tabular}{|c|c|c|c|}
\hline $\begin{array}{c}\text { Temperature } \\
\left({ }^{\circ} \mathrm{C}\right)\end{array}$ & $\begin{array}{c}\left(\mathrm{NH}_{3}\right)_{\text {free }}{ }^{*} \\
(\mathrm{~mol} / \mathrm{l})\end{array}$ & $\begin{array}{c}{\left[\mathrm{S}_{2} \mathrm{O}_{3}{ }^{2-}\right]^{* * *}} \\
(\mathrm{~mol} / \mathrm{l})\end{array}$ & $\frac{\left.\left[\mathrm{Cu}\left(\mathrm{S}_{2} \mathrm{O}_{3}\right)_{2}\right)_{3}{ }^{5-}\right]^{2}}{\left[\mathrm{Cu}\left(\mathrm{NH}_{3}\right)_{4}{ }^{2+}\right]}$ \\
\hline 50 & 0.647 & 0.036 & $7.94 \mathrm{E}+12$ \\
\hline 50 & 0.618 & 0.100 & $4.38 \mathrm{E}+15$ \\
\hline 30 & 0.638 & 0.036 & $1.99 \mathrm{E}+14$ \\
\hline 30 & 0.591 & 0.100 & $1.24 \mathrm{E}+17$ \\
\hline 50 & 0.015 & 0.036 & $2.92 \mathrm{E}+19$ \\
\hline 50 & 0.014 & 0.100 & $1.73 \mathrm{E}+22$ \\
\hline 30 & 0.004 & 0.036 & $8.28 \mathrm{E}+22$ \\
\hline 30 & 0.005 & 0.100 & $2.65 \mathrm{E}+25$ \\
\hline
\end{tabular}

* Calculated from the $\mathrm{NH}_{4}{ }^{+} / \mathrm{NH}_{3}$ equilibrium reaction, $\Delta G^{\circ}=-52.8 \mathrm{~kJ} / \mathrm{mol}$, using the observed $\mathrm{pH}$, temperature, and total ammonia concentration

** Actual free thiosulphate concentrations may be lower due to formation of the cuprousthiosulphate complex, $\mathrm{Cu}\left(\mathrm{S}_{2} \mathrm{O}_{3}\right)_{3}^{5-}$

It is, therefore, possible that the negative effect of copper concentration on cementation kinetics is due to decreased current efficiency caused by competition between the copper reduction reaction and the gold cementation reaction on the surface of copper particles. The negative effect of copper concentration may also be due to reaction of cupric 
tetrammine with deposited gold. This, of course, is the principle mechanism for copper catalysed thiosulphate leaching of gold.

\subsection{Results of the Rotating Disk Electrode Experiments}

The rotating disk electrode experiments were performed under conditions which were designed to eliminate deviations from first order kinetics and ensure that gold in solution existed as the gold-thiosulphate complex. Based on results from the powder cementation experiments, the temperature and ammonia concentration were lowered and sulphite and copper were completely eliminated. The resulting first order rate constants are presented in Table 4.6.

Table 4.6: Modelled Results of RDE Experiments. Initial Conditions: $12.5 \mathrm{ppm} \mathrm{Au,} 0.32$ $\mathrm{mol} / \mathrm{l} \mathrm{NH}_{3}(\mathrm{pH} 10.1), 0.2 \mathrm{~mol} / \mathrm{l} \mathrm{S}_{2} \mathrm{O}_{3}{ }^{2-}, \mathrm{V}_{\text {avg }} 985 \mathrm{ml}$

\begin{tabular}{|c|c|c|c|c|c|}
\hline $\begin{array}{c}\text { Temp. } \\
\left({ }^{\circ} \mathrm{C}\right)\end{array}$ & $\begin{array}{c}\text { Area Cu } \\
\left(\mathrm{cm}^{2}\right)\end{array}$ & $\begin{array}{c}\omega \\
(\mathrm{rad} / \mathrm{s})\end{array}$ & $\begin{array}{c}v^{*} \\
\left(\mathrm{~cm}^{2} / \mathrm{s} \times 10^{-2}\right)\end{array}$ & $\begin{array}{c}\mathrm{k}{ }^{\prime} \\
\left(\mathrm{s}^{-1} \times 10^{-5}\right)\end{array}$ & $\begin{array}{c}\mathrm{k}_{1}{ }^{\prime} \mathrm{V} / \mathrm{A} \omega^{1 / 2} \\
\left(\mathrm{~cm} / \mathrm{s}^{1 / 2} \times 10^{-4}\right)\end{array}$ \\
\hline 22 & 10.87 & 45.24 & 0.957 & 4.61 & 6.20 \\
\hline 35 & 11.34 & 44.82 & 0.719 & 7.69 & 9.82 \\
\hline 35 & 10.75 & 45.66 & 0.719 & 6.11 & 7.88 \\
\hline 35 & 10.87 & 93.93 & 0.719 & 9.55 & 8.88 \\
\hline 35 & 11.07 & 70.37 & 0.719 & 9.02 & 9.55 \\
\hline 50 & 11.34 & 46.08 & 0.553 & 12.8 & 17.1 \\
\hline
\end{tabular}

* Calculated using the density and absolute viscosity of water

The adjustments in solution conditions were successful in eliminating deviations from first order kinetics. For each calculated value of $\mathrm{k}_{1}{ }^{\prime}$, the corresponding correlation coefficient, $\mathrm{R}^{2}$, was greater than 0.99 , indicating excellent agreement with the 'linear' model describing first order kinetics. The term $\mathrm{k}_{1}{ }^{\prime} \mathrm{V} / \mathrm{A} \omega^{1 / 2}$ is an adjusted rate constant representing that part of the rate constant dependent on temperature, i.e. $0.62 \mathrm{D}^{2 / 3} / \mathrm{v}^{1 / 6}$ from equation 2.26. These adjusted rate constants were used to generate an Arrhenius plot, Figure 4.14, from which the activation energy for the cementation process was calculated to be $13.9 \pm 7.9 \mathrm{~kJ} / \mathrm{ml}$ ( $95 \%$ confidence). This result is not significantly different from the activation energy calculated in Section 4.2, $17.6 \pm 6.2 \mathrm{~kJ} / \mathrm{ml}(95 \%$ confidence). Although no inference can be made about possible variations in gold 
speciation under the different ammonia and thiosulphate concentrations tested, both results are indicative of diffusion controlled cementation.

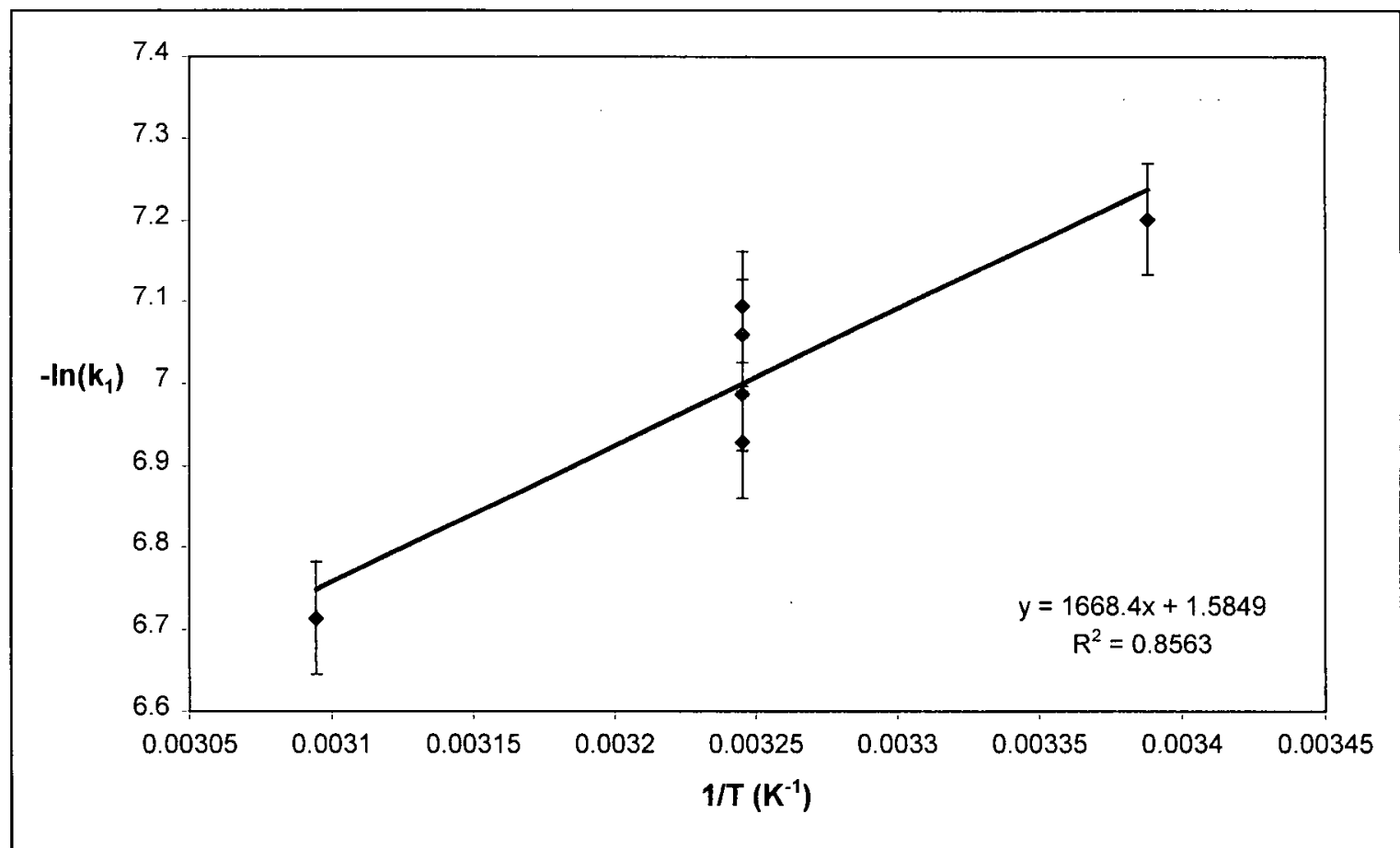

Figure 4.14: Arrhenius Plot Using Adjusted Rate Constant. Initial Conditions: $12.5 \mathrm{ppm}$ $\mathrm{Au}, 0.32 \mathrm{~mol} / 1 \mathrm{NH}_{3}(\mathrm{pH} 10.1), 0.2 \mathrm{~mol} / 1 \mathrm{~S}_{2} \mathrm{O}_{3}{ }^{2-}, \mathrm{V}_{\text {avg }} 985 \mathrm{ml}$

The diffusion coefficient for the gold-thiosulphate complex at $25^{\circ} \mathrm{C}$ is calculated to be $1.32 \times 10^{-5} \mathrm{~cm}^{2} / \mathrm{s}$, using the kinematic viscosity of water and the adjusted rate constant calculated from the regression formula of the Arrhenius plot. In comparison, the diffusion coefficient of the gold-cyanide complex, $\mathrm{Au}(\mathrm{CN})_{2}{ }^{-}$, is $1.331 \times 10^{-5} \mathrm{~cm}^{2} / \mathrm{s}^{[35]}$. The parity in diffusion coefficients adds further confidence to the results of the RDE experiments and reinforces the conclusion that cementation of gold by copper from ammoniacal thiosulphate solution is under mass transfer control.

\subsection{Summary}

The results of both powder cementation experiments and RDE experiments demonstrate that cementation of gold by copper from ammoniacal thiosulphate solution is controlled by diffusion of gold to the copper particle surface. No relationship could be established between changes in solution potential and the progress of the gold cementation reaction. 
This indicated that the oxidation/reduction of other species in solution dominates the measured solution potential. The first order rate constant, which includes the diffusion coefficient, governs the rate of removal of gold from solution and overall cementation performance. The factorial experiment allowed for development of a formula to predict the magnitude of measured rate constants in order to determine how the factors of temperature, $\mathrm{pH} / \mathrm{ammonia}$ concentration, initial copper concentration, initial thiosulphate concentration, and initial sulphite concentration affect cementation performance. The results established that increased temperature and a high $\mathrm{pH} / \mathrm{ammonia}$ concentration enhance cementation performance while the presence of sulphite and copper ions in solution negatively affect cementation performance. The positive effect of temperature can be explained by the associated decrease in solution viscosity which increases ionic mobility. X-ray diffraction and SEM analyses offers evidence of the formation of a transient copper-sulphur-oxygen precipitate, which later decomposes when dried to cuprite, $\mathrm{Cu}_{2} \mathrm{O}$, and some other sulphur bearing species. The proposed reasons for the effects of the other significant factors; $\mathrm{pH} / \mathrm{ammonia}$ concentration, initial copper concentration, and initial sulphite concentration are speculative and mainly related to how they might affect the formation and stability of this precipitate. 


\section{Conclusions}

The objective of this work was to determine which factors have important effects on the cementation kinetics of gold by copper in ammoniacal thiosulphate solution. The variables tested were; initial $\mathrm{pH} /$ ammonia concentration, copper concentration, thiosulphate concentration, sulphite concentration, temperature, and their interactive effects. It was concluded that increased temperature and a high $\mathrm{pH} / \mathrm{ammonia}$ concentration enhance cementation performance while the presence of sulphite and copper ions in solution negatively affect cementation performance. Measurement of changes is solution potential cannot be used to indicate the progress of the gold cementation reaction since measured solution potential is dominated by the mixed potential of side-reactions. Overall, the cementation process was determined to be under diffusion control.

The results of this study can be used in the design of the gold cementation stage of an industrial thiosulphate leaching operation. Control of the cementation stage cannot be accomplished by tracking of solution potential. The cementation unit should provide excellent mixing in order to maximise mass transfer. If the leach solution is to be heated or needs $\mathrm{pH}$ adjustment, these things should be done before contacting the solution with copper. Any required additions of sulphite or copper ions should be made after the cementation stage. 


\section{References}

${ }^{1}$ Perez A.E., et. al., U.S. Patent 4,654,078, 1987.

${ }^{2}$ Kerley B.J., U.S. Patent 4,369,061, 1983.

${ }^{3}$ Hu Jiexue, and Gon Qian, "Recovery of Gold from Thiosulphate Solution," Perth International Gold Conference, 1988.

${ }^{4}$ Gallagher N.P., "Interaction of Gold Cyanide, Thiocyanate, Thiosulphate, and Thiourea Complexes with Carbon Matrices," Thesis for the degree of Master of Science in Metallurgical Engineering, University of Nevada Reno, May 1987.

${ }^{5}$ Cao Changlin, Hu Jiexue, and Gong Qian, "Leaching of Gold by Low Concentration Thiosulphate Solutions," Transactions of Nonferrous Metals Society of China, Vol 4., Iss. 4, Nov. 1992.

${ }^{6}$ Kerley B.J., U.S. Patent 4,269,622, 1981.

${ }^{7}$ Flett D.S., Derry R., and Wilson J.C., "Chemical Study of thiosulphate leaching of silver sulphide," Trans. Instn. Min. Metall. (Sect. C Mineral Process. Extr. Metall.), 92, December 1983.

${ }^{8}$ Hemmati M., et. al., "Study of the thiosulphate leaching of gold from carbonaceous ore and the quantitative determination of thiosulphate in the leached solution," Extraction Metallurgy '89 Symp., Inst. Min. Metall., London, 1989.

${ }^{9}$ Zipperman D., Raghavan S., and Wilson J.P., "Gold and Silver Extraction by Ammoniacal Thiosulphate Leaching from a Rhyolite Ore," Hydrometallurgy, 19, 1988.

${ }^{10}$ Jiang Tao, Chen Jin, and Xu Shi, "Electrochemistry and Mechanism of Leaching Gold with Ammoniacal Thiosulphate," Gold Processing, Hydrometallurgy and Dewatering, AIMM Pub. No. 3/93, Vol. 5, pp 1141-1146, 1993.

${ }^{11}$ Abbruzzese C., et. al., "Thiosulphate Leaching for Gold Hydrometallurgy," Correspondence to S.Ubaldini, Instituto per il Trattamento dei Minerali (ITM) del CNR, Via Bolognola 7, 00137 Rome, Italy, 1995.

${ }^{12}$ Langhans J.W., "Heap Leaching of Refractory Gold Ores," EPRI Phase One Summary Report, 1993.

${ }^{13}$ Tozawa K, Inui Y., and Umetsu Y., "Dissolution of gold in ammoniacal thiosulphate solution," Paper presented at $110^{\text {th }}$ annual meeting of AIME, Chicago, Illinois, Feb. 1981. 
${ }^{14}$ Berezowsky R.M.G.S., and Sefton V.B., "Recovery of gold and silver from oxidation leach residues by ammoniacal thiosulphate leaching," Paper presented at 108th annual meeting of AIME, New Orleans, Louisiana, Feb. 1979.

${ }^{15}$ Awadalla F.T., and Ritcey G.M., "Recovery of Gold from Thiourea, Thiocyanate, or Thiosulphate Solutions by Reduction-Precipitation with a Stabalized form of Sodium Borohydride," Separation Science and Technology, 26(9), pp. 1207-1228, 1991.

${ }^{16}$ Lulham J., et. al., International Patent Application, WO 91/11539, 1991.

${ }^{17}$ Power G.P., and Ritchie I.M., "A Contribution to the Theory of Cementation (Metal Displacement) Reactions," Aust. J. Chem., 29, 1976.

${ }^{18}$ Miller J.D., "Solution Cementation and Purification," Rate Process Extr. Metall., Eds. Sohn H.Y., and Wadsworth M.E., Plenumn, New York, New York, U.S.A., pp. 95-117, 1979.

${ }^{19}$ Yannopoulos J.C., 'Recovery of Gold from Solutions,' The Extractive Metallurgy of Gold, Van Norstrand Reinhold, 1991.

${ }^{20}$ Fleming C.A., "Hydrometallurgy of precious metals recovery," Hydrometallurgy Theory and Practice, Eds. Cooper W.C. and Dreisinger D.B., Elesevier, Amsterdam, 1992.

${ }^{21}$ Power G.P., and Ritchie I.M., "Metal Displacement Reactions," Modern Aspects of Electrochemistry, No. 11, Eds. Conway B.E., and Brockris J.O'M., Plenum Press, New York, 1975.

${ }^{22}$ Van der Pas V., "A Fundamental Study of Cobalt Cementation with Zinc Dust in the Presence of Copper and Antimony Additives," Thesis for the degree of Master of Applied Science, Department of Metals and Materials Engineering, The University of British Colombia, 1995.

${ }^{23}$ Dreisinger D., "Mixing Theory for Hydrometallury," MMAT 458 course notes, The University of British Columbia, 1994.

${ }^{24}$ Albery W.J., 'Electrode Kinetics', Clareden Press, Oxford, 1975.

${ }^{25}$ Levich V.G., "Physicochemical Hydrodynamics," Prentice-Hall, Inc., Englewood Cliffs, New Jersey, pp. 60-78, 1962.

${ }^{26}$ Willard H.H., et. al., 'X-Ray Fluorescence Methods,' Instrumental Methods of Analysis, $7^{\text {th }}$ Ed., Wadsworth Publishing Company, Belmont, California, pp.367-372, 1988. 
${ }^{27}$ Peters E., "The physical chemistry of hydrometallurgy," International Symposium on Hydrometallurgy, Eds. Evans D.J.I. and Shoemaker R.S., 1973.

${ }^{28}$ Strange, R.S., "Introduction to Experimental Design for Chemists," Journal of Chemical Education, Vol. 67, No. 2, pp. 113-115, February 1990.

${ }^{29}$ Hogg R.V., and Ledolter J., "General Factorial and $2^{k}$ Factorial Experiments," Applied Statistics for Engineers and Physical Scientists, $2^{\text {nd }}$ Ed., Maxwell Macmillan Publishers, Toronto, pp. 318-333, 1992.

${ }^{30}$ Montgomery D.C., and Runger G.C., "Testing for Goodness of Fit," Applied Statistics and Probability for Engineers, John Wiley and Sons, Inc., pp. 444-453, 1994.

${ }^{31}$ Montgomery D.C., "Two-Level Fractional Factorial Designs," Design and Analysis of Experiments, $3^{\text {rd }}$ Ed., John Wiley and Sons, Inc., pp.335-349, 1991.

${ }^{32}$ Okinaka Y., and Osaka T., "Electroless Depostition Processes: Fundamentals and Applications," Advances in Electrochemical Science and Engineering, Vol. 3, New York, NY, VCH, pp. 56-114, 1990.

${ }^{33}$ Wassink B., "Analysis for Thiosulphate in the Presence of Sulphite, Sulphate, Copper(II) and Ammonia-Ammonium Buffer," Internal report, The University of British Columbia, 1994.

${ }^{34}$ Jeffery G.H., et. al., "Potassium," Vogel's textbook of Quantitative Chemical Analysis, $5^{\text {th }}$ Ed., John Wiley and Sons, Inc., New York, pp. 464-465, 1989.

${ }^{35}$ Lide D.R. (editor), CRC Handbook of Chemistry and Physics, $77^{\text {th }}$ Ed., CRC Press, Boca Raton, 1996.

${ }^{36}$ Wagman D.D., et. al., "NBS Technical Note 270-4," U.S. Government Printing Office, Washington D.C., 1982.

${ }^{37}$ Duby P., "The Thermodynamic Properties of Aqueous Inorganic Copper Systems," International Copper Research Association, Inc., U.S.A., 1977.

${ }^{38}$ Linkson P.B., "Precipitation of Metal Sulphites from Aqueous Liquors," Hydrometallurgy Research, Development and Plant Practice, Eds. Osseo-Asare K., and Miller J.D., The Metallurgical Society of AIME, pp. 311-327, 1983. 


\section{APPENDIX A: Procedure for Preparation of Standard Solutions Used for Atomic Absorption Spectroscopy Analysis}

In order to make up standard solutions for AA analysis a stock $1000 \mathrm{ppm}$ Au solution must first be prepared. In a $250 \mathrm{ml}$ beaker, add $75 \mathrm{ml}$ of concentrated $\mathrm{HCl}$ followed by $25 \mathrm{ml}$ of concentrated $\mathrm{HNO}_{3}$, i.e. $100 \mathrm{ml}$ of Aqua-Regia. Add a pre-weighed $1 \mathrm{~g}$ bar of $99.99 \% \mathrm{Au}$. After the bar has completely dissolved, pour the contents of the beaker into a one litre volumetric flask that is approximately $3 / 4$ full of deionised water. Carefully wash down all traces of the gold solution into volumetric flask. Dissolve in about $5 \mathrm{~g}$ of $\mathrm{KBr}$ in order to stabilise gold in solution. Allow the solution to cool to room temperature then fill to the line, cap, shake well, and store in a dark location.

In order to minimise matrix effects, the AA standards were prepared with levels of copper, sulphite, and thiosulphate, similar to the solution samples being analysed, e.g. 0.1 $\mathrm{g} / \mathrm{Cu}, 0.1 \mathrm{M} \mathrm{SO}_{3}{ }^{2-}$, and $0.1 \mathrm{M} \mathrm{S}_{2} \mathrm{O}_{3}{ }^{2-}$. With the levels of copper, sulphite and thiosulphate being common, two sets of AA standards were prepared, one with low ammonia, $0.2 \mathrm{M} \mathrm{NH}_{3}$, and the other with the higher level, $0.7 \mathrm{M} \mathrm{NH}_{3}$. In a $500 \mathrm{ml}$ volumetric flask, add $0.196 \mathrm{~g}$ of $\mathrm{CuSO}_{4} .5 \mathrm{H}_{2} \mathrm{O}$ and $16.67 \mathrm{ml}$ of concentrated $\mathrm{NH}_{4} \mathrm{OH}$ (if the high $\mathrm{NH}_{3}$ standard is being prepared). Fill to approximately $3 / 4$ with deionised water and shake until the copper sulphate has dissolved. Add $6.30 \mathrm{~g}$ of $\mathrm{Na}_{2} \mathrm{SO}_{3}$ and $7.41 \mathrm{~g}$ of $\left(\mathrm{NH}_{4}\right)_{2} \mathrm{~S}_{2} \mathrm{O}_{3}$. Shake until these salts have completely dissolved and then fill the flask to the bottom of the neck with water. Starting with the most dilute standard, add the required volume of $1000 \mathrm{ppm} \mathrm{Au}$ standard to the volumetric flask, e.g. $0 \mathrm{ml}$ for $0 \mathrm{ppm}$, $0.5 \mathrm{ml}$ for $1 \mathrm{ppm}, 1 \mathrm{ml}$ for $2 \mathrm{ppm}, 2.5 \mathrm{ml}$ for $5 \mathrm{ppm}$, and $5 \mathrm{ml}$ for $10 \mathrm{ppm}$. Fill to the line with distilled water, shake well, transfer into a clean $500 \mathrm{ml}$ Nalgene container, and store in a dark location. These standards contain several metastable species which will decompose over time and should be thrown out and prepared again every two to three weeks. 


\section{APPENDIX B: Procedure for Analysis of Thiosulphate in the Presence of Sulphite, Sulphate, Copper(II) and Ammonia-Ammonium Buffer}

The first step in preparing to analyse unknown solutions for thiosulphate is to make up a standard stock solution of known thiosulphate concentration. Prepare a $0.1 \mathrm{M}$ thiosulphate solution by dissolving $25 \mathrm{~g} \mathrm{Na}_{2} \mathrm{~S}_{2} \mathrm{O}_{3} \cdot 5 \mathrm{H}_{2} \mathrm{O}$ and $10 \mathrm{mg}$ of $\mathrm{HgI}_{2}$ in one litre of freshly boiled deionised water which has been $\mathrm{pH}$ adjusted to about 9 by the addition of 0.1 to $0.2 \mathrm{~g} \mathrm{Na}_{2} \mathrm{CO}_{3}$. Standardisation of this solution can be accomplished by using a $0.025 \mathrm{M} \mathrm{KIO}_{3}$ solution which is prepared by dissolving $5.350 \mathrm{~g}$ of $\mathrm{KIO}_{3}(99.9 \%$ dried at $120^{\circ} \mathrm{C}$ for one hour) in 1 litre of deionised water. Into a $250 \mathrm{ml}$ Erlenmeyer flask, pipette $20 \mathrm{ml}$ of $0.025 \mathrm{M} \mathrm{KIO}_{3}$. Add $1.6 \mathrm{~g}$ of $\mathrm{KI}$ and $5 \mathrm{ml}$ of $1 \mathrm{M} \mathrm{H}_{2} \mathrm{SO}_{4}$. Immediately titrate with thiosulphate solution until the solution's colour becomes straw yellow. Add deionised water to increase the solution volume to $200 \mathrm{ml}$ and add $2 \mathrm{ml}$ of starch indicator. Continue the titration until the last trace of blue colour disappears. The concentration of thiosulphate is given by the following formula:

$\left[\mathrm{S}_{2} \mathrm{O}_{3}{ }^{2-}\right]=\frac{20 \mathrm{ml} \times 0.025 \mathrm{M} \times 6}{(\text { Vol. } \mathrm{ml})}$

The range of thiosulphate concentration in the solutions being tested was such that a sample size of $10 \mathrm{ml}$ was selected. To analyse a solution sample for thiosulphate, thiosulphate and sulphite ions are first adsorbed onto a strong base anion exchange resin, e.g. Spectra Gel 1 X8. The ion exchange column is prepared by adding $7.5 \mathrm{~g}$ of resin with an equal amount of water to a $50 \mathrm{ml}$ burette equipped with a glass wool plug at the bottom. The column is then washed, first with $30 \mathrm{ml}$ of $1 \mathrm{M} \mathrm{NaNO}_{3}$ then next with $30 \mathrm{ml}$ of deionised water. A column prepared in this manner will have a capacity of about 10 mmol of negative charge. The unknown sample is drained through the resin until the liquid level dips into the glass wool plug. Nitrogen pressure can be employed to achieve an adequate flow rate of about $2 \mathrm{ml} / \mathrm{min}$. The gas delivery system need not be complicated. A plastic Y connector can be fitted atop the burette by means of a hollowed out No. 00 rubber stopper. One end of the $Y$ connector is connected to a tank of compressed nitrogen and the other to a tube and pinch clamp for flow regulation. Next, the column is washed with $30 \mathrm{ml}$ of water in $4 \times 5 \mathrm{ml}$ aliquots followed by the remaining 
$10 \mathrm{ml}$, allowing the liquid level to drain into the glass wool with each aliquot. Place a clean $100 \mathrm{ml}$ beaker under the ion exchange column and then elute the column with 35 $\mathrm{ml}$ of $1 \mathrm{M} \mathrm{NaNO}_{3}$ at a flow rate of $2 \mathrm{ml} / \mathrm{min}$, first with $5 \mathrm{ml}$, then with the remaining 30 $\mathrm{ml}$. As the eluate is being collected pipette $20 \mathrm{ml}$ of $0.025 \mathrm{M} \mathrm{KIO}_{3}$ into a $250 \mathrm{ml}$ Erlenmeyer flask. To the beaker add about $0.9 \mathrm{ml}$ of $37 \%$ formaldehyde, to mask sulphite, and two drops of phenolphthalein indicator. Stir the solution and neutralise with dropwise addition of $0.2 \mathrm{M} \mathrm{H}_{2} \mathrm{SO}_{4}$ until the solution become only faintly pink. Quickly dissolve $1.6 \mathrm{~g}$ of $\mathrm{KI}$ in the Erlenmeyer flask containing the $\mathrm{KIO}_{3}$ solution followed by 5 $\mathrm{ml}$ of $1 \mathrm{M} \mathrm{H}_{2} \mathrm{SO}_{4}$. Making sure to carefully wash down all traces of the eluate, pour the eluate solution into the Erlenmeyer flask. Titrate this solution with the standard thiosulphate solution until the colour is light yellow. Add enough water to make up the volume to about $200 \mathrm{ml}$. Add $2 \mathrm{ml}$ of starch indicator and continue titration until solution becomes clear and colourless. Near the end the blue colour fades slowly and care must be taken not to overshoot the endpoint. The thiosulphate concentration in the sample is calculated as follows:

$\left[\mathrm{S}_{2} \mathrm{O}_{3}{ }^{2-}\right]_{\text {sample }}=\frac{\left(\text { Vol. } \mathrm{IO}_{3}{ }^{-}\right) \times\left[\mathrm{IO}_{3}{ }^{-}\right] \times 6-\left(\text { Vol. Stnd. } \mathrm{S}_{2} \mathrm{O}_{3}{ }^{2-}\right) \times\left[\mathrm{S}_{2} \mathrm{O}_{3}{ }^{2-}\right]_{\text {Stnd }}}{\text { Vol. Sample }}$ 


\section{APPENDIX C: Procedure for Determination of Ammonia in Solution}

Ammonia can be precipitated from solution as ammonium tetraphenylborate (TPB), $\mathrm{NH}_{4}\left[\mathrm{~B}\left(\mathrm{C}_{6} \mathrm{H}_{5}\right)_{4}\right]$, by addition of standard TPB solution. The standard TPB solution is prepared by dissolving 3 grams of accurately weighed sodium tetraphenylborate, $\mathrm{Na}\left[\mathrm{B}\left(\mathrm{C}_{6} \mathrm{H}_{5}\right)_{4}\right]$, in $500 \mathrm{ml}$ of deionised water.

In a clean dry beaker, along with a pre-weighed magnetic stir bar, pipette a suitable quantity of a solution for which the amount of ammonia is to be determined. Place this beaker within a larger beaker containing ice water. Place both beakers on a magnetic stir plate and stir the solution throughout the precipitation process. Slowly add excess TPB solution. Note: So as not to waste TPB solution, if the upper limit of ammonia in the sample is known then the amount of TPB solution added should be calculated based on this value. Vacuum filter the precipitate using a Buchner funnel containing a preweighed paper filter. Pour the filtrate back into the original beaker and shake vigorously in order to collect any residual precipitate, then filter again. Repeat this process as many time as necessary. The final step in filtration is to wash the precipitate with a small quantity of ice cold deionised water. Place the filter paper, containing the precipitate and the stir bar, into a drying oven and dry for 1 hour at $120^{\circ} \mathrm{C}$. Weigh the filter paper to determine the amount of precipitate collected. The calculation for concentration of ammonia in the sample is as follows:

$\left[\mathrm{NH}_{3}\right]_{\text {Sample }}=\frac{\text { Mass of ppt. (g) }}{337.274 \times \text { Vol. Sample (1) }}$ 


\section{APPENDIX D: Derivation of the 'Passivation' Model}

The general first order expression for a cementation process appears below:

$\frac{\partial \mathrm{C}}{\partial \mathrm{t}}=-\mathrm{k}_{1}\left(\frac{\mathrm{A}}{\mathrm{V}}\right) \mathrm{C}$

Normally, the area over which the reaction takes place, $\mathrm{A}$, is considered to be constant

and independent of time. Let us assume that the reaction area is being diminished as time goes on by the formation of a passivating layer. In order to keep the model

mathematically simple, let us further assume that the passivating layer forms with zeroth order kinetics.

$\frac{\mathrm{dA}}{\mathrm{dt}}=-\mathrm{k}_{2}$

Integrating the above expression yields the following equation:

$\mathrm{A}=\mathrm{A}_{0}-\mathrm{k}_{2} \mathrm{t}$

Substituting the above expression into the general first order expression gives the equation below:

$\frac{\mathrm{dC}}{\mathrm{dt}}=-\mathrm{k}_{1}\left(\frac{\mathrm{A}_{0}-\mathrm{k}_{2} \mathrm{t}}{\mathrm{V}}\right) \mathrm{C}$

Integrating yields the form of the final equation.

$\ln \left(\frac{\mathrm{C}_{\mathrm{t}}}{\mathrm{C}_{0}}\right)=-\mathrm{k}_{1}\left(\frac{\mathrm{A}_{0}}{\mathrm{~V}}\right) \mathrm{t}+\left(\frac{\mathrm{k}_{1} \mathrm{k}_{2}}{2 \mathrm{~V}}\right) \mathrm{t}^{2}$

The term $\mathrm{k}_{1} \mathrm{k}_{2} / 2 \mathrm{~V}$ corrects for non-linear behaviour due to the formation of a passivating layer. 
APPENDIX E: Analysis of Variance of $\mathbf{k}_{\mathbf{1}}{ }^{\prime}$

\begin{tabular}{|c|c|c|c|c|c|}
\hline SOIRCF & $\begin{array}{l}\text { SUM OF } \\
\text { SOUARFS }\end{array}$ & $D F$ & $\begin{array}{l}\text { MEAN } \\
\text { SOUARE }\end{array}$ & $\begin{array}{l}\text { F } \\
\text { VALUE }\end{array}$ & PROB $>F$ \\
\hline MODEL & 0.00000788 & 4 & 2.0E-06 & 23.87 & $<0.0001$ \\
\hline RESIDUAL & 0.00000091 & 11 & $8.2 \mathrm{E}-08$ & & \\
\hline COR TOTAL & 0.00000878 & 15 & & & \\
\hline ROOT MSE & 0.00028719 & & \multicolumn{2}{|c|}{ R-SOUARED } & 0.90 \\
\hline DEP MEAN & 0.00128106 & & ADJ & UARED & 0.86 \\
\hline C.V. $\%$ & 22.41800656 & & PRED R & UARED & 0.78 \\
\hline
\end{tabular}

Predicted Residual Sum of Squares (PRESS) $=1.9 \mathrm{E}-06$

\begin{tabular}{llllll} 
& \multicolumn{2}{l}{ COEFFICIEN } & \multicolumn{2}{l}{ STANDARD $\mathrm{t}$ FOR H0 } & \\
FACTOR & ESTIMATE & DF & ERROR & COEFFICIENT $=0$ & PROB $>|\mathrm{t}|$ \\
& & & & & \\
INTERCEPT & 0.00128106 & 1 & 0.00007180 & & \\
A & -0.00017681 & 1 & 0.00007180 & -2.46 & 0.0315 \\
C & -0.00035044 & 1 & 0.00007180 & -4.88 & 0.0005 \\
D & 0.00049231 & 1 & 0.00007180 & 6.86 & $<0.0001$ \\
E & 0.00030956 & 1 & 0.00007180 & 4.31 & 0.0012
\end{tabular}

Final Equation in Terms of Coded Factors

$\mathrm{k}_{1}{ }^{\prime}=0.00128-0.00018 \times \mathrm{A}-0.00035 \times \mathrm{C}+0.00049 \times \mathrm{D}+0.00031 \times \mathrm{E}$

Final Equation in Terms of Uncoded Factors

$\mathrm{k}_{1}{ }^{\prime}=-0.00032-0.00354 \times[\mathrm{Cu}]-0.00701 \times\left[\mathrm{SO}_{3}{ }^{2-}\right]+0.00197 \times\left[\mathrm{NH}_{3}\right]+0.00003 \times \mathrm{T}$ 


\begin{tabular}{|c|c|c|c|c|c|c|c|c|}
\hline OBS & ACTUAL & PREDICT & RESIDUAL & & STUDENT & COOK'S & OUTLIER & RUN \\
\hline ORD & VALUE & VALUE & & LEVER & RESID & DIST & T VALUE & ORD \\
\hline 1 & $1.61 \mathrm{E}-3$ & $1.63 \mathrm{E}-3$ & $-1.26 \mathrm{E}-5$ & 0.312 & -0.053 & 0.000 & -0.050 & 4 \\
\hline 2 & $3.98 \mathrm{E}-4$ & $6.53 \mathrm{E}-4$ & $-2.55 \mathrm{E}-4$ & 0.312 & -1.070 & 0.104 & -1.078 & 14 \\
\hline 3 & $9.79 \mathrm{E}-4$ & $1.01 \mathrm{E}-3$ & $-2.74 E-5$ & 0.312 & -0.115 & 0.001 & -0.110 & 15 \\
\hline 4 & $1.08 \mathrm{E}-3$ & $1.27 \mathrm{E}-3$ & $-1.93 \mathrm{E}-4$ & 0.312 & -0.810 & 0.060 & -0.797 & 10 \\
\hline 5 & $3.47 \mathrm{E}-4$ & $3.06 \mathrm{E}-4$ & $4.14 \mathrm{E}-5$ & 0.312 & 0.174 & 0.003 & 0.166 & 12 \\
\hline 6 & $2.80 \mathrm{E}-4$ & $5.71 \mathrm{E}-4$ & $-2.91 E-4$ & 0.312 & -1.222 & 0.136 & -1.254 & 9 \\
\hline 7 & $1.18 \mathrm{E}-3$ & $9.25 \mathrm{E}-4$ & $2.50 \mathrm{E}-4$ & 0.312 & 1.051 & 0.100 & 1.057 & 1 \\
\hline 8 & $4.39 \mathrm{E}-4$ & $-4.81 E-5$ & $4.87 \mathrm{E}-4$ & 0.312 & 2.045 & 0.380 & 2.477 & 8 \\
\hline 9 & $1.94 \mathrm{E}-3$ & $1.99 \mathrm{E}-3$ & $-5.01 E-5$ & 0.312 & -0.210 & 0.004 & -0.201 & 6 \\
\hline 10 & $2.63 \mathrm{E}-3$ & $2.26 \mathrm{E}-3$ & $3.75 \mathrm{E}-4$ & 0.312 & 1.577 & 0.226 & 1.709 & 13 \\
\hline 11 & $2.68 \mathrm{E}-3$ & $2.61 \mathrm{E}-3$ & $7.28 \mathrm{E}-5$ & 0.312 & 0.306 & 0.008 & 0.293 & 3 \\
\hline 12 & $1.73 \mathrm{E}-3$ & $1.64 \mathrm{E}-3$ & $8.96 \mathrm{E}-5$ & 0.312 & 0.376 & 0.013 & 0.361 & 7 \\
\hline 13 & $1.57 \mathrm{E}-3$ & $1.91 \mathrm{E}-3$ & $-3.39 E-4$ & 0.312 & -1.425 & 0.185 & -1.505 & 11 \\
\hline 14 & $5.86 \mathrm{E}-4$ & 9.37E-4 & $-3.51 E-4$ & 0.312 & -1.472 & 0.197 & -1.566 & 2 \\
\hline 15 & $1.36 \mathrm{E}-3$ & $1.29 \mathrm{E}-3$ & $6.48 \mathrm{E}-5$ & 0.312 & 0.272 & 0.007 & 0.260 & 16 \\
\hline 16 & $1.69 \mathrm{E}-3$ & $1.56 \mathrm{E}-3$ & $1.37 \mathrm{E}-4$ & 0.312 & 0.577 & 0.030 & 0.558 & 5 \\
\hline
\end{tabular}




\section{APPENDIX F: Calculation of Free Energy Change for Reduction of Sulphite and Thiosulphate to Chalcocite and Cuprite by Metallic Copper}

Consider the reduction reaction of sulphite to cuprite and chalcocite by metallic copper:

$6 \mathrm{Cu}+\mathrm{SO}_{3}{ }^{2-}+2 \mathrm{H}^{+} \rightarrow \mathrm{Cu}_{2} \mathrm{~S}+2 \mathrm{Cu}_{2} \mathrm{O}+\mathrm{H}_{2} \mathrm{O}$

$\Delta \mathrm{G}^{\circ}=-128.78 \mathrm{~kJ} / \mathrm{mol}$

By assuming the activities of non-ionic species to be unity, the change in free energy for this reaction becomes dependent on only sulphite concentration, $\mathrm{pH}$ and temperature.

$\Delta \mathrm{G}=\Delta \mathrm{G}^{\circ}+\mathrm{R} T \ln (\mathrm{k})$

$\Delta \mathrm{G}=-128780-8.3145 \times \mathrm{T} \times \ln \left(\left[\mathrm{SO}_{3}{ }^{2-}\right]\right)+38.290 \times \mathrm{T} \times \mathrm{pH}$

The free energies for this reaction under the various solution conditions tested are tabulated below:

\begin{tabular}{|c|c|c|c|}
\hline $\begin{array}{c}{\left[\mathrm{SO}_{3}{ }^{2-}\right]} \\
(\mathrm{mol} / \mathrm{l})\end{array}$ & $\begin{array}{c}\text { Temperature } \\
(\mathrm{K})\end{array}$ & $\mathrm{pH}$ & $\begin{array}{c}\Delta \mathrm{G} \\
(\mathrm{kJ} / \mathrm{mol})\end{array}$ \\
\hline 0.1 & 323 & 9.6 & -3.9 \\
\hline 0.1 & 323 & 7.4 & -31.1 \\
\hline 0.1 & 303 & 9.6 & -11.6 \\
\hline 0.1 & 303 & 7.4 & -37.1 \\
\hline
\end{tabular}

Consider the reduction reaction of thiosulphate to cuprite and chalcocite by metallic copper:

$8 \mathrm{Cu}+\mathrm{S}_{2} \mathrm{O}_{3}{ }^{2-}+2 \mathrm{H}^{+} \rightarrow 2 \mathrm{Cu}_{2} \mathrm{~S}+2 \mathrm{Cu}_{2} \mathrm{O}+\mathrm{H}_{2} \mathrm{O}$

$\Delta \mathrm{G}^{\circ}=-182.86 \mathrm{~kJ} / \mathrm{mol}$

$\Delta \mathrm{G}=-182860-8.3145 \times \mathrm{T} \times \ln \left(\left[\mathrm{S}_{2} \mathrm{O}_{3}{ }^{2-}\right]\right)+38.290 \times \mathrm{T} \times \mathrm{pH}$

\begin{tabular}{|c|c|c|c|}
\hline $\begin{array}{c}{\left[\mathrm{S}_{2} \mathrm{O}_{3}{ }^{2-}\right]} \\
(\mathrm{mol} / \mathrm{l})\end{array}$ & $\begin{array}{c}\text { Temperature } \\
(\mathrm{K})\end{array}$ & $\mathrm{pH}$ & $\begin{array}{c}\Delta \mathrm{G} \\
(\mathrm{kJ} / \mathrm{mol})\end{array}$ \\
\hline 0.1 & 323 & 9.6 & -57.9 \\
\hline 0.1 & 323 & 7.4 & -85.2 \\
\hline 0.1 & 303 & 9.6 & -65.7 \\
\hline 0.1 & 303 & 7.4 & -91.2 \\
\hline 0.04 & 323 & 9.6 & -55.5 \\
\hline 0.04 & 323 & 7.4 & -87.2 \\
\hline 0.04 & 303 & 9.6 & -63.5 \\
\hline 0.04 & 303 & 7.4 & -88.9 \\
\hline
\end{tabular}


Note that it is not claimed that cuprite and chalcocite are the products of sulphite or thiosulphate reduction, only that these precipitated species are two possible products of reduction of sulphite and/or thiosulphate by reaction with metallic copper. 


\section{APPENDIX G: Calculation of Theoretical Change in Sulphite Concentration Caused by Reduction of Sulphite on Metallic Copper to Cuprite and Chalcocite}

The reduction reaction of sulphite on metallic copper to cuprite and chalcocite is given below:

$6 \mathrm{Cu}+\mathrm{SO}_{3}{ }^{2-}+2 \mathrm{H}^{+} \rightarrow \mathrm{Cu}_{2} \mathrm{~S}+2 \mathrm{Cu}_{2} \mathrm{O}+\mathrm{H}_{2} \mathrm{O}$

Assuming that the amount of cuprite formed is equal to the detection limit of the Siemens D5000 X-ray diffractometer, used for analysis of the copper powder residues, i.e. 5 percent of the copper powder used $(0.25 \mathrm{~g})$, the total number of moles of cuprite formed may be calculated as follows:

$\mathrm{mol} \mathrm{Cu} 2 \mathrm{O}=\frac{0.25 \mathrm{~g}}{143.09 \mathrm{~g} / \mathrm{mol}}=0.00175 \mathrm{~mol}$

The stoichiometric amount of sulphite required to produce the above quantity of cuprite is $0.00087 \mathrm{~mol} \mathrm{SO}_{3}^{2-}$ (half the number of moles of cuprite). The theoretical change in concentration of sulphite in a 3.75 litre solution is calculated below:

$\Delta\left[\mathrm{SO}_{3}{ }^{2-}\right]=\frac{0.00087 \mathrm{~mol}}{3.75 \mathrm{l}}=0.00023 \mathrm{~mol} / 1$

Repeating this exercise assuming different products of reduction such as $\mathrm{Cu}_{2} \mathrm{O}$ and $\mathrm{S}^{\circ}$ or CuS leads to similar results. 


\section{APPENDIX H: Results of Thiosulphate Analyses}

\begin{tabular}{|c|c|c|c|c|c|c|c|c|}
\hline \multicolumn{5}{|c|}{ Initial Solution Conditions } & \multirow{2}{*}{$\begin{array}{c}\text { Cementing } \\
\text { Agent }\end{array}$} & \multirow{2}{*}{$\begin{array}{l}\text { Initial } \\
{\left[\mathrm{S}_{2} \mathrm{O}_{3}{ }^{2-}\right]} \\
(\mathrm{mol} / \mathrm{l})\end{array}$} & \multirow{2}{*}{$\begin{array}{l}\text { Final } \\
{\left[\mathrm{S}_{2} \mathrm{O}_{3}{ }^{2-}\right]} \\
(\mathrm{mol} / \mathrm{l})\end{array}$} & \multirow{2}{*}{$\begin{array}{c}\text { Change } \\
{\left[\mathrm{S}_{2} \mathrm{O}_{3}{ }^{2-}\right]} \\
(\mathrm{mol} / \mathrm{l})\end{array}$} \\
\hline $\begin{array}{l}\text { Temp } \\
\left({ }^{\circ} \mathrm{C}\right)\end{array}$ & $\begin{array}{c}\left(\mathrm{NH}_{3}\right) \\
(\mathrm{mol} / \mathrm{l})\end{array}$ & $\begin{array}{c}{\left[\mathrm{Cu}^{2+}\right]} \\
(\mathrm{g} / \mathrm{l})\end{array}$ & $\begin{array}{l}{\left[\mathrm{SO}_{3}{ }^{2-}\right]} \\
(\mathrm{mol} / \mathrm{l})\end{array}$ & $\begin{array}{l}{\left[\mathrm{Au}^{+}\right]} \\
(\mathrm{ppm})\end{array}$ & & & & \\
\hline 50 & 0.73 & 1.0 & 0.1 & 13.33 & $1.33 \mathrm{~g} / \mathrm{l} \mathrm{Cu}$ & 0.4 & 0.4 & 0.0 \\
\hline 50 & 0.73 & 1.0 & 0.1 & 13.33 & $1.33 \mathrm{~g} / \mathrm{l} \mathrm{Cu}$ & 0.0 & 0.0 & 0.0 \\
\hline 50 & 0.73 & 1.0 & 0.0 & 13.33 & $0.05 \mathrm{~g} / \mathrm{l} \mathrm{Zn}$ & 0.1 & 0.073 & 0.027 \\
\hline 50 & 0.73 & 0.0 & 0.1 & 13.33 & $1.33 \mathrm{~g} / \mathrm{l} \mathrm{Cu}$ & 0.1 & 0.1 & 0.0 \\
\hline 60 & 0.73 & 1.0 & 0.1 & 13.33 & $1.33 \mathrm{~g} / \mathrm{l} \mathrm{Cu}$ & 0.1 & 0.034 & 0.066 \\
\hline
\end{tabular}




\section{APPENDIX I: Data from Powder Cementation Experiments Testing Reproducibility}

\begin{tabular}{|c|c|c|c|c|c|}
\hline \multirow{2}{*}{$\begin{array}{c}\text { Time } \\
(\mathrm{min})\end{array}$} & \multicolumn{5}{|c|}{$[\mathrm{Au}](\mathrm{t})(\mathrm{ppm})$} \\
\cline { 2 - 6 } & Run \#1 & Run \#2 & Run \#3 & Run \#4 & Run \#5 \\
\hline 0 & 13.36 & 13.44 & 13.95 & 13.01 & 13.49 \\
\hline 1 & 12.75 & 12.80 & 13.16 & 12.96 & 12.74 \\
\hline 5 & 10.71 & 10.91 & 11.07 & 9.58 & 10.85 \\
\hline 10 & 8.81 & 8.91 & 8.70 & 7.86 & 8.94 \\
\hline 15 & 7.37 & 7.36 & 7.32 & 6.44 & 7.49 \\
\hline 20 & 6.17 & 6.36 & 6.13 & 5.57 & 6.20 \\
\hline 30 & 4.57 & 4.56 & 4.47 & 4.63 & 4.64 \\
\hline 45 & 3.12 & 2.99 & 2.89 & 2.56 & 2.92 \\
\hline 60 & 2.17 & 2.14 & 1.95 & 1.70 & 2.14 \\
\hline 90 & 1.23 & 1.09 & 0.93 & 0.91 & 1.12 \\
\hline
\end{tabular}

\begin{tabular}{|c|c|c|c|c|c|}
\hline \multirow{2}{*}{$\begin{array}{c}\text { Time } \\
(\mathrm{min})\end{array}$} & \multicolumn{5}{|c|}{$\mathrm{pH}$} \\
\cline { 2 - 6 } & Run \#1 & Run \#2 & Run \#3 & Run \#4 & Run \#5 \\
\hline 0 & 9.04 & 9.01 & 8.94 & 8.86 & 8.75 \\
\hline 1 & 9.04 & 9.00 & 8.97 & 8.93 & 8.74 \\
\hline 5 & 9.04 & 9.01 & 9.03 & 8.98 & 8.77 \\
\hline 10 & 9.04 & 9.01 & 9.04 & 9.01 & 8.77 \\
\hline 15 & 9.06 & 9.01 & 9.04 & 9.04 & 8.77 \\
\hline 20 & 9.06 & 9.01 & 9.04 & 9.04 & 8.75 \\
\hline 30 & 9.06 & 9.01 & 9.03 & 9.04 & 8.75 \\
\hline 45 & 9.06 & 9.00 & 9.01 & 9.04 & 8.74 \\
\hline 60 & 9.07 & 9.00 & 9.00 & 9.04 & 8.72 \\
\hline 90 & 9.07 & 9.00 & 9.00 & 9.04 & 8.68 \\
\hline
\end{tabular}

\begin{tabular}{|c|c|c|c|c|c|}
\hline \multirow{2}{*}{$\begin{array}{c}\text { Time } \\
(\mathrm{min})\end{array}$} & \multicolumn{5}{|c|}{$\mathrm{E}_{\text {SCE }}(\mathrm{mV})$} \\
\hline 0 & Run \#1 & Run \#2 & Run \#3 & Run \#4 & Run \#5 \\
\hline 1 & -190 & -182 & -193 & -199 & -214 \\
\hline 5 & -202 & -191 & -203 & -205 & -224 \\
\hline 10 & -216 & -205 & -223 & -223 & -237 \\
\hline 15 & -225 & -212 & -260 & -227 & -250 \\
\hline 20 & -214 & -188 & -270 & -240 & -253 \\
\hline 30 & -227 & -204 & -278 & -246 & -256 \\
\hline 45 & -244 & -200 & -281 & -253 & -256 \\
\hline 60 & -245 & -200 & -280 & -250 & -255 \\
\hline 90 & -240 & -195 & -278 & -253 & -248 \\
\hline
\end{tabular}


APPENDIX J: Data from Powder Cementation Experiments to Determine the Rate Control Regime

\begin{tabular}{|c|c|c|c|c|c|}
\hline \multirow{2}{*}{$\begin{array}{c}\text { Time } \\
(\min )\end{array}$} & \multicolumn{5}{|c|}{$[\mathrm{Au}](\mathrm{t})(\mathrm{ppm})$} \\
\cline { 2 - 6 } & $60{ }^{\circ} \mathrm{C}$ & $50{ }^{\circ} \mathrm{C}$ & $40{ }^{\circ} \mathrm{C}$ & $31{ }^{\circ} \mathrm{C}$ & $18{ }^{\circ} \mathrm{C}$ \\
\hline 0 & & 13.45 & 13.74 & 14.04 & 14.00 \\
\hline 1 & 13.14 & 12.88 & 13.26 & 13.78 & 13.96 \\
\hline 5 & 11.39 & 10.62 & 11.63 & 12.49 & 13.17 \\
\hline 10 & 8.64 & 8.64 & 10.11 & 10.90 & 12.04 \\
\hline 15 & 7.31 & 7.20 & 8.95 & 9.59 & 10.89 \\
\hline 20 & 5.87 & 6.08 & 7.86 & 8.28 & 9.88 \\
\hline 30 & 4.40 & 4.57 & 5.75 & 6.54 & 8.32 \\
\hline 45 & 2.73 & 2.89 & 4.03 & 4.62 & 6.59 \\
\hline 60 & 1.83 & 2.02 & 2.93 & 3.45 & 5.30 \\
\hline 90 & 0.85 & 1.05 & 1.69 & 2.04 & 3.55 \\
\hline
\end{tabular}

\begin{tabular}{|c|c|c|c|c|c|}
\hline \multirow{2}{*}{$\begin{array}{c}\text { Time } \\
(\min )\end{array}$} & \multicolumn{5}{|c|}{$\mathrm{pH}$} \\
\cline { 2 - 6 } & $60{ }^{\circ} \mathrm{C}$ & $50{ }^{\circ} \mathrm{C}$ & $40^{\circ} \mathrm{C}$ & $31^{\circ} \mathrm{C}$ & $18^{\circ} \mathrm{C}$ \\
\hline 0 & 8.75 & 9.04 & 9.24 & 9.58 & 9.92 \\
\hline 1 & 8.74 & 9.04 & 9.30 & 9.57 & 9.90 \\
\hline 5 & 8.77 & 9.04 & 9.32 & 9.58 & 9.92 \\
\hline 10 & 8.77 & 9.04 & 9.32 & 9.59 & 9.94 \\
\hline 15 & 8.77 & 9.06 & 9.32 & 9.61 & 9.94 \\
\hline 20 & 8.75 & 9.06 & 9.32 & 9.63 & 9.93 \\
\hline 30 & 8.75 & 9.06 & 9.30 & 9.63 & 9.93 \\
\hline 45 & 8.74 & 9.06 & 9.29 & 9.63 & 9.93 \\
\hline 60 & 8.72 & 9.07 & 9.27 & 9.63 & 9.93 \\
\hline 90 & 8.68 & 9.07 & 9.24 & 9.63 & 9.95 \\
\hline
\end{tabular}

\begin{tabular}{|c|c|c|c|c|c|}
\hline \multirow{2}{*}{$\begin{array}{c}\text { Time } \\
(\mathrm{min})\end{array}$} & \multicolumn{5}{|c|}{$\mathrm{E}_{\mathrm{SCE}}(\mathrm{mV})$} \\
\hline 0 & $60{ }^{\circ} \mathrm{C}$ & $50{ }^{\circ} \mathrm{C}$ & $40^{\circ} \mathrm{C}$ & $31{ }^{\circ} \mathrm{C}$ & $18{ }^{\circ} \mathrm{C}$ \\
\hline 1 & -214 & -190 & -198 & -194 & -197 \\
\hline 5 & -224 & -191 & -204 & -200 & -202 \\
\hline 10 & -237 & -202 & -22 & -210 & -210 \\
\hline 15 & -250 & -216 & -226 & -222 & -223 \\
\hline 20 & -253 & -225 & -228 & -233 & -230 \\
\hline 30 & -257 & -214 & -230 & -242 & -235 \\
\hline 45 & -256 & -244 & -245 & -253 & -235 \\
\hline 60 & -255 & -245 & -242 & -261 & -227 \\
\hline 90 & -248 & -240 & -244 & -245 & -226 \\
\hline
\end{tabular}


APPENDIX K: Data from Factorial Experiment

\begin{tabular}{|c|c|c|c|c|c|c|c|c|}
\hline \multirow{2}{*}{$\begin{array}{l}\text { Time } \\
(\min )\end{array}$} & \multicolumn{8}{|c|}{$[\mathrm{Au}](\mathrm{t})(\mathrm{ppm})$} \\
\hline & Std. \#1 & Std. \#2 & Std. \#3 & Std. \#4 & Std. \#5 & Std. \#6 & Std. \#7 & Std. \#8 \\
\hline 0 & 13.69 & 14.06 & 13.76 & 13.58 & 13.49 & 12.79 & 13.80 & 13.49 \\
\hline 1 & 12.63 & 14.17 & 13.42 & 12.67 & 13.56 & 12.75 & 13.19 & 13.34 \\
\hline 2 & 11.36 & 13.28 & 12.70 & 11.74 & 13.36 & 12.61 & 12.02 & 13.06 \\
\hline 4 & 9.44 & 12.66 & 10.43 & 9.50 & 12.59 & 12.02 & 9.61 & 12.08 \\
\hline 10 & 5.52 & 11.40 & 7.80 & 7.16 & 11.37 & 10.92 & 7.00 & 10.54 \\
\hline 15 & 3.78 & 10.05 & 5.84 & 5.52 & 10.27 & 10.44 & 5.28 & 9.38 \\
\hline 20 & 2.68 & 8.77 & 4.46 & 4.29 & 9.40 & 9.50 & 4.02 & 8.49 \\
\hline 30 & 1.47 & 8.29 & 2.58 & 2.66 & 7.96 & 8.43 & 2.46 & 7.15 \\
\hline 45 & 0.79 & 6.03 & 1.18 & 1.29 & 6.65 & 7.46 & 1.16 & 5.71 \\
\hline 60 & 0.45 & 5.17 & 0.48 & 0.66 & 5.65 & 6.63 & 0.61 & 4.69 \\
\hline \multirow{2}{*}{$\begin{array}{l}\text { Time } \\
(\mathrm{min})\end{array}$} & \multicolumn{8}{|c|}{$[\mathrm{Au}](\mathrm{t})(\mathrm{ppm})$} \\
\hline & Std. $\# 9$ & Std. $\# 10$ & Std. \#11 & Std. \#12 & Std. \#13 & Std. \#14 & Std. \#15 & Std. \#16 \\
\hline 0 & 13.72 & 12.70 & 13.72 & 12.45 & 13.86 & 12.56 & 14.04 & 12.91 \\
\hline 1 & 12.33 & 10.94 & 11.75 & 11.55 & 12.73 & 12.54 & 13.23 & 11.68 \\
\hline 2 & 11.01 & 9.24 & 10.07 & 10.16 & 11.52 & 12.28 & 12.37 & 10.29 \\
\hline 4 & 7.80 & 6.03 & 6.40 & 7.59 & 8.68 & 11.12 & 9.67 & 7.86 \\
\hline 10 & 4.39 & 3.01 & 3.12 & 4.46 & 5.73 & 9.40 & 6.54 & 4.97 \\
\hline 15 & 2.56 & 1.63 & 1.63 & 2.55 & 3.67 & 8.05 & 4.50 & 3.21 \\
\hline 20 & 1.54 & 0.98 & 0.88 & 1.63 & 2.83 & 7.04 & 3.24 & 2.24 \\
\hline 30 & 0.65 & 0.40 & 0.35 & 0.72 & 1.51 & 5.60 & 1.76 & 1.08 \\
\hline 45 & & & & & 0.75 & 4.28 & 0.83 & 0.37 \\
\hline 60 & & & & & 0.42 & 4.04 & 0.52 & \\
\hline
\end{tabular}

\begin{tabular}{|c|c|c|c|c|c|c|c|c|}
\hline \multirow{2}{*}{$\begin{array}{l}\text { Time } \\
(\mathrm{min})\end{array}$} & \multicolumn{8}{|c|}{$\mathrm{pH}$} \\
\hline & Std. \#1 & Std. \#2 & Std. \#3 & Std. \#4 & Std. $\# 5$ & Std. $\# 6$ & Std. \#7 & Std. $\# 8$ \\
\hline 0 & 7.48 & 7.43 & 7.42 & 7.42 & 7.41 & 7.42 & 7.37 & 7.51 \\
\hline 60 & 7.44 & 7.55 & 7.57 & 7.47 & 7.43 & 7.42 & 7.39 & \\
\hline \multirow{2}{*}{$\begin{array}{l}\text { Time } \\
(\mathrm{min})\end{array}$} & \multicolumn{8}{|c|}{$\mathrm{pH}$} \\
\hline & Std. \#9 & Std. \#10 & Std. \#11 & Std. \#12 & Std. \#13 & Std. \#14 & Std. \#15 & Std. \#16 \\
\hline 0 & 9.82 & 9.55 & 9.31 & 9.68 & 9.29 & 10.00 & 9.77 & 9.26 \\
\hline 60 & 9.88 & 9.58 & 9.29 & 9.70 & 9.29 & 10.04 & 9.78 & 9.26 \\
\hline
\end{tabular}




\begin{tabular}{|c|c|c|c|c|c|c|c|c|}
\hline \multirow{2}{*}{$\begin{array}{c}\text { Time } \\
(\mathrm{min})\end{array}$} & \multicolumn{9}{|c|}{ ESCE $_{\text {SIV }}$} \\
\cline { 2 - 9 } & Std. \#1 & Std. \#2 & Std. \#3 & Std. \#4 & Std. \#5 & Std. \#6 & Std. \#7 & Std. \#8 \\
\hline 0 & -74 & -39 & -63 & -119 & -50 & -75 & -172 & -66 \\
\hline 1 & -76 & -67 & -67 & -121 & -60 & -87 & -180 & -72 \\
\hline 2 & -80 & -73 & -70 & -123 & -65 & -92 & -186 & -72 \\
\hline 4 & -87 & -90 & -72 & -123 & -70 & -108 & -193 & -75 \\
\hline 10 & -94 & -104 & -77 & -122 & -70 & -118 & -188 & -80 \\
\hline 15 & -96 & -110 & -85 & -122 & -70 & -125 & -188 & -80 \\
\hline 20 & -98 & -110 & -85 & -122 & -85 & -140 & -184 & -80 \\
\hline 30 & -105 & -115 & -90 & -121 & -90 & -150 & -183 & -90 \\
\hline 45 & -110 & -110 & -90 & -120 & -85 & -162 & -188 & -87 \\
\hline 60 & -112 & -110 & -95 & -117 & -85 & -190 & -196 & -87 \\
\hline Time & & & & ESCE & $(\mathrm{mV})$ & & & \\
\cline { 2 - 10 }$(\mathrm{min})$ & Std. \#9 & Std. \#10 & Std. \#11 & Std. \#12 & Std. \#13 & Std. \#14 & Std. \#15 & Std. \#16 \\
\hline 0 & -74 & -49 & -43 & -52 & -173 & -109 & -132 & -159 \\
\hline 1 & -80 & -76 & -73 & -65 & -180 & -117 & -137 & -160 \\
\hline 2 & -89 & -89 & -89 & -73 & -175 & -123 & -129 & -160 \\
\hline 4 & -116 & -110 & -109 & -93 & -180 & -130 & -120 & -170 \\
\hline 10 & -141 & -152 & -135 & -118 & -192 & -130 & -120 & -186 \\
\hline 15 & -155 & -172 & -150 & -135 & -200 & -129 & -120 & -185 \\
\hline 20 & -164 & -185 & -156 & -145 & -195 & -130 & -116 & -185 \\
\hline 30 & -176 & -203 & -172 & -161 & -208 & -129 & -117 & -192 \\
\hline 45 & -184 & -212 & -172 & -170 & -215 & -131 & -117 & -198 \\
\hline 60 & -186 & -211 & -174 & -172 & -210 & -135 & -119 & -200 \\
\hline
\end{tabular}


APPENDIX L: Data from RDE Experiments

\begin{tabular}{|c|c|c|c|c|c|c|}
\hline \multirow{4}{*}{$\begin{array}{l}\text { Time } \\
\text { (min) }\end{array}$} & \multicolumn{6}{|c|}{$[\mathrm{Au}](\mathrm{t})(\mathrm{ppm})$} \\
\hline & $22^{\circ} \mathrm{C}$ & $35^{\circ} \mathrm{C}$ & $50^{\circ} \mathrm{C}$ & $35^{\circ} \mathrm{C}$ & $35^{\circ} \mathrm{C}$ & $35^{\circ} \mathrm{C}$ \\
\hline & $\begin{array}{c}10.87 \\
\mathrm{~cm}^{2} \mathrm{Cu}\end{array}$ & $\begin{array}{c}11.34 \\
\mathrm{~cm}^{2} \mathrm{Cu}\end{array}$ & $\begin{array}{c}10.75 \\
\mathrm{~cm}^{2} \mathrm{Cu}\end{array}$ & $\begin{array}{c}10.87 \\
\mathrm{~cm}^{2} \mathrm{Cu}\end{array}$ & $\begin{array}{c}11.02 \\
\mathrm{~cm}^{2} \mathrm{Cu}\end{array}$ & $\begin{array}{c}11.34 \\
\mathrm{~cm}^{2} \mathrm{Cu}\end{array}$ \\
\hline & $\begin{array}{c}45.24 \\
\mathrm{rad} / \mathrm{s}\end{array}$ & $\begin{array}{l}45.66 \\
\mathrm{rad} / \mathrm{s}\end{array}$ & $\begin{array}{c}46.08 \\
\mathrm{rad} / \mathrm{s}\end{array}$ & $\begin{array}{l}93.93 \\
\mathrm{rad} / \mathrm{s}\end{array}$ & $\begin{array}{l}70.37 \\
\mathrm{rad} / \mathrm{s}\end{array}$ & $\begin{array}{l}44.82 \\
\mathrm{rad} / \mathrm{s}\end{array}$ \\
\hline 0 & 12.37 & 12.74 & 13.24 & 12.25 & 12.62 & 12.26 \\
\hline 15 & 11.86 & 11.92 & 11.39 & 11.31 & 11.47 & 11.49 \\
\hline 30 & 11.37 & 11.09 & 10.46 & 10.34 & 10.76 & 10.81 \\
\hline 60 & & 9.62 & 9.05 & 8.86 & 9.18 & 9.59 \\
\hline$\overline{90}$ & 9.26 & 8.52 & 7.86 & 7.49 & 7.82 & 8.83 \\
\hline 120 & 8.31 & 7.33 & 6.93 & 6.54 & 6.75 & 7.41 \\
\hline
\end{tabular}

\begin{tabular}{|c|c|c|c|c|c|c|}
\hline \multirow{4}{*}{$\begin{array}{l}\text { Time } \\
(\min )\end{array}$} & \multicolumn{6}{|c|}{$\mathrm{E}_{\mathrm{SCE}}(\mathrm{mV})$} \\
\hline & $22^{\circ} \mathrm{C}$ & $35^{\circ} \mathrm{C}$ & $50^{\circ} \mathrm{C}$ & $35^{\circ} \mathrm{C}$ & $35^{\circ} \mathrm{C}$ & $35^{\circ} \mathrm{C}$ \\
\hline & $\begin{array}{c}10.87 \\
\mathrm{~cm}^{2} \mathrm{Cu}\end{array}$ & $\begin{array}{c}11.34 \\
\mathrm{~cm}^{2} \mathrm{Cu}\end{array}$ & $\begin{array}{c}10.75 \\
\mathrm{~cm}^{2} \mathrm{Cu}\end{array}$ & $\begin{array}{c}10.87 \\
\mathrm{~cm}^{2} \mathrm{Cu}\end{array}$ & $\begin{array}{c}11.02 \\
\mathrm{~cm}^{2} \mathrm{Cu}\end{array}$ & $\begin{array}{c}11.34 \\
\mathrm{~cm}^{2} \mathrm{Cu}\end{array}$ \\
\hline & $\begin{array}{l}45.24 \\
\mathrm{rad} / \mathrm{s}\end{array}$ & $\begin{array}{l}45.66 \\
\mathrm{rad} / \mathrm{s}\end{array}$ & $\begin{array}{c}46.08 \\
\mathrm{rad} / \mathrm{s}\end{array}$ & $\begin{array}{l}93.93 \\
\mathrm{rad} / \mathrm{s}\end{array}$ & $\begin{array}{l}70.37 \\
\mathrm{rad} / \mathrm{s}\end{array}$ & $\begin{array}{l}44.82 \\
\mathrm{rad} / \mathrm{s}\end{array}$ \\
\hline 0 & -632 & -621 & -654 & -640 & -644 & -641 \\
\hline 15 & -665 & -668 & -694 & -691 & & -673 \\
\hline 30 & -682 & -684 & -701 & -695 & -677 & -688 \\
\hline 60 & -694 & -691 & -697 & -696 & -684 & -693 \\
\hline 90 & -694 & -691 & -700 & -696 & -684 & -693 \\
\hline 120 & -695 & -690 & -699 & -696 & -684 & -693 \\
\hline
\end{tabular}




\section{Appendix M: Thermodynamic Data}

\begin{tabular}{|c|c|c|c|}
\hline \multirow[t]{2}{*}{ Species* } & \multirow[t]{2}{*}{ Source } & \multicolumn{2}{|c|}{$\Delta \mathrm{G}_{\mathrm{f}}^{0}$} \\
\hline & & $\mathrm{kcal} / \mathrm{mol}$ & $\mathrm{kJ} / \mathrm{mol}$ \\
\hline $\mathrm{Au}(\mathrm{s})$ & & 0.0 & 0.0 \\
\hline $\mathrm{HAuO}_{3}{ }^{2-}$ & 36 & -34.0 & -142.0 \\
\hline $\mathrm{H}_{2} \mathrm{AuO}_{3}^{-}$ & 36 & -52.2 & -218.4 \\
\hline $\mathrm{H}_{3} \mathrm{AuO}_{3}$ & 36 & -67.75 & -283.47 \\
\hline $\mathrm{AuO}_{3}{ }^{3-}$ & 36 & -12.4 & -51.9 \\
\hline $\mathrm{Au}(\mathrm{OH})_{3}(\mathrm{~s})$ & 36 & -75.77 & -317.02 \\
\hline $\mathrm{Au}\left(\mathrm{NH}_{3}\right)_{2}{ }^{+}$ & 9 & -9.8 & -41.1 \\
\hline $\mathrm{Au}\left(\mathrm{S}_{2} \mathrm{O}_{3}\right)_{2}{ }^{3-}$ & 9 & -250.8 & -1048. \\
\hline $\mathrm{Cu}(\mathrm{s})$ & & 0.0 & 0.0 \\
\hline $\mathrm{Cu}^{+}$ & 36 & 11.95 & 50.00 \\
\hline $\mathrm{Cu}^{2+}$ & 36 & 15.66 & 65.52 \\
\hline $\mathrm{Cu}^{3+}$ & 37 & 72.5 & 303.3 \\
\hline $\mathrm{Cu}_{2} \mathrm{O}(\mathrm{s})$ & 36 & -34.9 & -146.0 \\
\hline $\mathrm{CuO}(\mathrm{s})$ & 36 & -31.0 & -129.7 \\
\hline $\mathrm{Cu}(\mathrm{OH})^{+}$ & 37 & -31 & -130 \\
\hline $\mathrm{Cu}_{2}(\mathrm{OH})_{2}{ }^{2+}$ & 37 & -67 & -280 \\
\hline $\mathrm{Cu}(\mathrm{OH})_{2}$ & 36 & -59.53 & -249.08 \\
\hline $\mathrm{HCuO}_{2}^{-}$ & 36 & -61.8 & -258.6 \\
\hline $\mathrm{CuO}_{2}^{2-}$ & 36 & -43.9 & -183.7 \\
\hline $\mathrm{Cu}(\mathrm{OH})_{2}(\mathrm{~s})$ & 37 & -85.8 & -359.0 \\
\hline $\mathrm{CuO}_{2}^{-}$ & 37 & -26.9 & -112.6 \\
\hline $\mathrm{Cu}(\mathrm{OH})_{3}(\mathrm{~s})$ & 37 & -105.8 & -442.7 \\
\hline $\mathrm{Cu}\left(\mathrm{NH}_{3}\right)_{2}{ }^{+}$ & 37 & -15.6 & -65.3 \\
\hline $\mathrm{Cu}\left(\mathrm{NH}_{3}\right)^{2+}$ & 36 & 3.72 & 15.56 \\
\hline $\mathrm{Cu}\left(\mathrm{NH}_{3}\right)_{2}{ }^{2+}$ & 36 & -7.28 & -30.46 \\
\hline $\mathrm{Cu}\left(\mathrm{NH}_{3}\right)_{3}{ }^{2+}$ & 36 & -17.48 & -73.14 \\
\hline $\mathrm{Cu}\left(\mathrm{NH}_{3}\right)_{4}{ }^{2+}$ & 36 & -26.60 & -111.3 \\
\hline $\mathrm{Cu}\left(\mathrm{NH}_{3}\right)_{5}{ }^{2+}$ & 36 & -32.13 & -134.43 \\
\hline $\mathrm{Cu}_{2} \mathrm{~S}$ & 36 & -20.6 & -86.2 \\
\hline $\mathrm{CuS}$ & 36 & -12.8 & -53.6 \\
\hline $\mathrm{CuSO}_{3}{ }^{-}$ & 36 & -115.0 & -481.2 \\
\hline $\mathrm{Cu}_{2} \mathrm{SO}_{3}$ & 36 & -92.4 & -386.6 \\
\hline $\mathrm{Cu}\left(\mathrm{SO}_{3}\right)_{2}{ }^{3-}$ & 36 & -232.4 & -972.4 \\
\hline $\mathrm{Cu}\left(\mathrm{SO}_{3}\right)_{3}{ }^{5-}$ & 36 & -349.7 & -1463.2 \\
\hline $\mathrm{CuSO}_{3} \cdot \mathrm{Cu}_{2} \mathrm{SO}_{3} \cdot 2 \mathrm{H}_{2} \mathrm{O}(\mathrm{s})$ & 38 & -341 & -1427 \\
\hline
\end{tabular}




\begin{tabular}{|l|c|c|c|}
\hline $\mathrm{CuS}_{2} \mathrm{O}_{3}{ }^{-}$ & 37 & -129. & -540. \\
\hline $\mathrm{Cu}\left(\mathrm{S}_{2} \mathrm{O}_{3}\right)_{2}{ }^{3-}$ & 37 & -259. & -1084 \\
\hline $\mathrm{Cu}\left(\mathrm{S}_{2} \mathrm{O}_{3}\right)_{3}{ }^{5-}$ & 37 & -388. & -1623. \\
\hline $\mathrm{H}^{+}$ & & 0.0 & 0.0 \\
\hline $\mathrm{H}_{2} \mathrm{O}(1)$ & 37 & -56.687 & -237.18 \\
\hline $\mathrm{OH}^{-}$ & 37 & -37.594 & -157.29 \\
\hline $\mathrm{NH}_{3}$ & 37 & -6.35 & -26.57 \\
\hline $\mathrm{NH}_{4}{ }^{+}$ & 37 & -18.97 & -79.37 \\
\hline $\mathrm{S}^{2-}$ & 37 & 20.5 & 85.8 \\
\hline $\mathrm{HS}^{-}$ & 37 & 2.88 & 12.05 \\
\hline $\mathrm{H}_{2} \mathrm{~S}^{2-}$ & 37 & -6.66 & -27.87 \\
\hline $\mathrm{S}_{2}{ }^{2-}$ & 37 & 19.0 & 79.5 \\
\hline $\mathrm{S}_{3}{ }^{2-}$ & 37 & 17.6 & 73.6 \\
\hline $\mathrm{S}_{4}{ }^{2-}$ & 37 & 16.5 & 69.0 \\
\hline $\mathrm{S}_{5}{ }^{2-}$ & 37 & 33.6 & 140.6 \\
\hline $\mathrm{S}^{(\mathrm{s})}$ & & 0.0 & 0.0 \\
\hline $\mathrm{S}_{2} \mathrm{O}_{3}{ }^{2-}$ & 36 & -123.977 & -518.72 \\
\hline $\mathrm{S}_{2} \mathrm{O}_{4}{ }^{2-}$ & 37 & -143.5 & -600.4 \\
\hline $\mathrm{HS}_{2} \mathrm{O}_{4}^{-}$ & 37 & -146.9 & -614.6 \\
\hline $\mathrm{H}_{2} \mathrm{~S}_{2} \mathrm{O}_{4}$ & 37 & -147.4 & -616.7 \\
\hline $\mathrm{SO}_{2}{ }^{2}$ & 37 & -71.871 & -300.71 \\
\hline $\mathrm{SO}_{3}{ }^{2-}$ & 37 & -116.3 & -486.6 \\
\hline $\mathrm{HSO}_{3}{ }^{-}$ & 37 & -126.15 & -527.82 \\
\hline $\mathrm{S}_{2} \mathrm{O}_{6}{ }^{2-}$ & 37 & -231. & -967. \\
\hline $\mathrm{HSO}_{3}$ & 37 & -128.56 & -537.9 \\
\hline $\mathrm{SO}_{4}{ }^{2-}$ & -177.97 & -744.63 \\
\hline $\mathrm{HSO}_{4}{ }^{-}$ & 37 & -180.69 & -756.01 \\
\hline $\mathrm{S}_{2} \mathrm{O}_{8}{ }^{2-}$ & -265.4 & -1110.4 \\
\hline $\mathrm{H}_{2} \mathrm{~S}_{2} \mathrm{O}_{8}$ & -265.4 & -1110.4 \\
\hline
\end{tabular}

* all species are aqueous unless otherwise indicated 